\title{
Urogenital micro-organisms in pregnancy
}

Citation for published version (APA):

Vonsée, H. J. (1989). Urogenital micro-organisms in pregnancy. [Doctoral Thesis, Maastricht University]. Rijksuniversiteit Limburg. https://doi.org/10.26481/dis.19891130hv

Document status and date:

Published: 01/01/1989

DOI:

10.26481/dis.19891130hv

Document Version:

Publisher's PDF, also known as Version of record

\section{Please check the document version of this publication:}

- A submitted manuscript is the version of the article upon submission and before peer-review. There can be important differences between the submitted version and the official published version of record.

People interested in the research are advised to contact the author for the final version of the publication, or visit the DOI to the publisher's website.

- The final author version and the galley proof are versions of the publication after peer review.

- The final published version features the final layout of the paper including the volume, issue and page numbers.

Link to publication

\footnotetext{
General rights rights.

- You may freely distribute the URL identifying the publication in the public portal. please follow below link for the End User Agreement:

www.umlib.nl/taverne-license

Take down policy

If you believe that this document breaches copyright please contact us at:

repository@maastrichtuniversity.nl

providing details and we will investigate your claim.
}

Copyright and moral rights for the publications made accessible in the public portal are retained by the authors and/or other copyright owners and it is a condition of accessing publications that users recognise and abide by the legal requirements associated with these

- Users may download and print one copy of any publication from the public portal for the purpose of private study or research.

- You may not further distribute the material or use it for any profit-making activity or commercial gain

If the publication is distributed under the terms of Article $25 \mathrm{fa}$ of the Dutch Copyright Act, indicated by the "Taverne" license above, 


\section{UROGENITAL MICRO-ORGANISMS IN PREGNANCY}

Chlamydia trachomatis, Mycoplasma hominis,

Ureaplasma urealyticum and asymptomatic bacteriuria 


\section{Urogenital micro-organisms in pregnancy}

\section{Proefschrift}

ter verkrijging van de graad van doctor

aan de Rijksuniversiteit Limburg te Maastricht, op gezag van de Rector Magnificus, Prof. dr F.I.M. Bonke, volgens het besluit van het College van Dekanen, in het openbaar te verdedigen op donderdag, 30 november 1989 om 16.00 uur

door

Henk John Vonsée

geboren te Paramaribo, Suriname in 1955 


\section{Urogenital micro-organisms in pregnancy}

\section{Proefschrift}

ter verkrijging van de graad van doctor

aan de Rijksuniversiteit Limburg te Maastricht, op gezag van de Rector Magnificus, Prof. dr F.I.M. Bonke, volgens het besluit van het College van Dekanen, in het openbaar te verdedigen

op donderdag, 30 november 1989 om 16.00 uur

door

\section{Henk John Vonsée}

geboren te Paramaribo, Suriname in 1955 


\section{Promotores:}

Prof. dr C.P.A. van Boven

Prof. drJ. de Haan

\section{Co-promotor:}

Dr E.E. Stobberingh

\section{Beoordelingscommissie:}

Prof. dr J.P.M. Geraedts (voorzitter)

Prof. dr T.K.A.B. Eskes

Prof. dr J.A. Knottnerus

Prof. dr W.J.B.M. van der Staak

Prof. dr H.A. Valkenburg

Vonsée, Henk John

Urogenital micro-organisms in pregnancy / Henk

John Vonsese; [ill. by the author]. - Maastricht :

Datuwyse. - III.

Thesis Maastricht - Wirh summary in Dutch.

ISBN 90-5291-011-1

SISO 605.5 UDC 6 $\| 8.3(043.3)$

Subject headings: Chlamydia trachomatis /

mycoplasma hominis / atsymptomatic bacteriuriat.

Produktic en layout: Datawyse Maastricht

Omslagontwerp: Ton Houben

Druk: Krips Repro Meppel 
Aan Han

Nienke en Jitske en mijn ouders 


\section{Contents}

1 Introduction

1.1 Contribution of gestational age and birth weight to neonatal mortality and morbidity

1.2 Causes of preterm delivery and decreased birth weight

1.3 Objectives of the present study 11

1.4 Outline of the thesis

2 Review of the literature

2.1 Chlamydia trachomatis 15

1 History 15

2 Biology 16

3 Prevalence in non-pregnant women 18

4 Prevalence in pregnant women 19

5 Association between prematurity and the presence of maternal Chlamydia trachomatis 21

6 Association between small-for-date children and the presence of maternal Chlamydia trachomatis 25

2.2 Mycoplasma hominis and Ureaplasma urealyticum 27

1 History 27

2 Biology 27

3 Prevalence in non-pregnant women 28

4 Prevalence in pregnant women 29

5 Association between the presence of maternal Mycoplasma hominis and Ureaplasma urealyticum and prematurity

6 Association between small-for-date children and the presence of maternal Mycoplasma hominis and Ureaplasma urealyticum $\quad 32$

2.3 Asymptomatic bacteriuria 34

1 Prevalence in pregnancy 34

2 Association between prematurity, small-fordates and asymptomatic bacteriuria $\quad 35$

2.4 Discussion 36

3 Population and Methods

3.1 Study design and study population 43

3.2 Eligibility criteria 44

3.3 Aims and procedures 44

3.4 Registered data and definitions 45 
3.5 Specimen collection and laboratory procedures 48

1 Chlamydia trachomatis 48

2 Mycoplasma hominis and Ureaplasma urealyticum

49

3 Asymptomatic bacteriuria $\quad 50$

3.6 Data collection and handling 50

$\begin{array}{ll}3.7 & \text { Statistical analyses } \\ & 50\end{array}$

$4 \quad$ Results

4.1 Study group $\quad 55$

1 Characteristics at enrollment 56

2 Reproductive history 59

3 Medical risk factors 61

4 Pregnancy outcome data $\quad 62$

4.2 Prevalence of Chlamydia trachomatis, Mycoplasma hominis, Ureaplasma urealyticum and asymptomatic bacteriuria

1 Relation of Chlamydia trachomatis, Mycoplasma hominis, Ureaplasma urealyticum, and asymptomatic bacteriuria with gestational age at delivery and birth weight

2 Relation of demographic, behavioural, and medical variables with gestational age at delivery and birth weight

4.3 Differences in birth weight and gestational age at delivery between categories of demographic, behavioural, and medical variables

1 Further investigation of demographic, behavioural and medical variables

4.4 Chlamydia trachomatis 76

5 Summary and Discussion

6 Samenvatting en Discussie

Addenda

Dankwoord 


\section{Introduction}

"only when the factors causing prematurity are clearly understood, can any intelligent attempt at prevention be made" [1]

\subsection{Contribution of gestational age and birth weight to neonatal mortality and morbidity}

In the past 35 years there has been a dramatic decrease in neonatal mortality due to improvements in neonatal and perinatal care. Much of the improved neonatal survival has been achieved by a reduction of the death rate of infants born at term. Today, the principal contribution to neonatal mortality is constituted by preterm born infants. At least $75 \%$ of neonatal deaths, not attributable to congenital malformations, result from premature delivery [2].

Preterm labour or preterm rupture of the membranes, resulting in delivery before 37 weeks of gestation, occurs in approximately $5 \%$ to $8 \%$ of pregnancies [2]. Despite the introduction of tocolytic therapy and improvements in the diagnosis of multiple gestation by ultrasound, the rate of premature births has remained almost constant. As other causes of perinatal morbidity and mortality have decreased, the problem of preterm delivery has become relatively more prominent.

A smaller contribution to neonatal mortality is constituted by the smallfor-date child. Approximately $3 \%$ to $7 \%$ of all pregnancies will result in the birth of such a child. These infants constitute up to $18 \%$ of all neonatal deaths. Moreover, a birth weight small-for-gestational age is associated with an increased incidence of neonatal morbidity [3].

Apart from increased acute neonatal problems, premature born or smallfor-date infants will suffer significantly more often from long-term sequelae such as mental retardation, visual and hearing impairment, and cerebral palsy. The potential advantages of reducing the total number of these infants are self-evident.

In summary, prematurity and a small-for-gestational-age birth weight are the two most important remaining contributors to neonatal mortality 
and morbidity. Attempts to a further reduction of the neonatal mortality and morbidity rate should therefore be directed at identifying preventable causes of premature birth and decreased birth weight.

\subsection{Causes of preterm delivery and decreased birth weight}

For the majority of women, the causes of preterm labour and preterm rupture of membranes are poorly understood. A variety of medical and epidemiological risk factors are known, all of which may contribute to an increased likelihood of preterm birth. Among these are, for example, multiple pregnancies, urinary tract infections, maternal age, and maternal education level. However, the ways in which these underlying epidemiological or medical risk factors contribute to the onset of preterm labour often remain unclear. A major question in the understanding of preterm labour is whether it is the result of a physiological, but premature, activation of the mechanisms involved in the onset of parturition at term, or is the result of an external trigger.

Recently, maternal uro-genital infections have been postulated to cause a proportion of preterm labour [7]. This presumption is based on recovery of organisms from amniotic fluid of women in preterm labour, reduction of prematurity among pregnant women with asymptomatic bacteriuria treated with antibiotics, frequent histological evidence of chorio-amnionitis among women with preterm deliveries and correlation of prematurity with antepartum or intrapartum colonization of the cervix and the vagina by a number of specific micro-organisms.

The mechanisms by which maternal uro-genital infection may be related to preterm labour or a decreased birth weight remain speculative. They may involve effects of inflammation or synthesis and release of prostaglandins.

There is conflicting evidence regarding a possible causal role for Chlamydia trachomatis in the development of preterm labour [4-6]. However, studies demonstrating a beneficial effect of tetracycline and erythromycin therapy during pregnancy on the prevalence of prematurity implicate the existence of a micro-organism (sensitive to these antibiotics) that contributes to prematurity $[7,8]$. In addition, the ability of Chlamydia trachomatis to proliferate in human amnion cells with at replication cycle that brings about cell death, and the association of Chlamydia trachomatis with a mucopurulent endocervical inflammatory process, make it a likely candidate on theoretical grounds. 
Also evidence is mounting that in addition to Chlamydia trachomatis, Mycoplasma hominis and Ureaplasma urealyticum, commonly known as the genital mycoplasmata, are associated with an adverse pregnancy outcome. Recent studies have drawn attention to the importance of both micro-organisms in the development of decreased birth weight, preterm birth and chronic infection of the central nervous system in preterm infants [9].

In contrast to infections of the maternal genital tract, which have onlly recently been related to an impaired outcome of pregnancy, asymptomatic bacteriuria has been accused of causing preterm delivery and fetal growth retardation since the early sixties [10]. Numerous studies have been performed to support or dispute the suggested association $[11,12]$. Most investigators could not confirm these findings, but a few did and the debate is still open.

The results of many of the studies addressing the issue of maternal uro-genital infections in relation to preterm birth and small-for-dates have been inconsistent. Explanations for these inconsistencies include the size of the study populations, appropriateness of control groups, and heterogeneity of populations studied. Also failure to apply uniform criteria (serological testing for infection versus cell culture), adequately to determine gestational age, to control for a multiplicity of confounding factors or to test for the presence of co-existing infections all limit the interpretation of the results.

\subsection{Objectives of the present study}

Since a small-for-date birth weight and preterm delivery are major contributors to neonatal mortality and morbidity, their preventable causes should be identified. A reduction of the incidence of these two obstetric outcomes is a major public health goal.

Screening for Chlamydia trachomatis, both the mycoplasmata and asymptomatic bacteriuria in pregnancy is time consuming. In addition the tests for detection of Chlamydia trachomatis and the mycoplasmata are expensive. Whether a programme aimed at screening and subsequent treatment with antibiotics to prevent adverse pregnancy outcomes or neonatal sequelae is worthwhile and cost effective, depends largely on the magnitude of adverse pregnancy outcomes due to these micro-organisms and their prevalence in the local population. 
The present study was performed to determine the prevalence of Chlamydia trachomatis, Mycoplasma hominis, Ureaplasma urealyticum and asymptomatic bacteriuria in a sample of pregnant women of two antenatal clinics in the southern part of the Netherlands. The data were analyzed in order to investigate if there was an association in these women between the presence of any of the micro-organisms and preterm birth or small-for-date infants. The same association was also sought between the presence of maternal asymptomatic bacteriuria and both adverse outcomes of pregnancy.

The aims of this study were in particular:

1. to determine the endocervical prevalence of Chlamydia trachomatis, Mycoplasma hominis and Ureaplasma urealyticum and the prevalence of asymptomatic bacteriuria among a group of pregnant women.

2. to compare the history and pregnancy outcome of culture-positive patients with those of culture-negative patients in order to determine whether there were associations between the endocervical presence of the micro-organisms or asymptomatic bacteriuria and preterm labour or decreased birth weight.

3. to investigate the role of maternal demographic, behavioural and medical variables on birth weight and gestational age in the same group of pregnant women.

4. to formulate recommendations with regard to the effectiveness of screening of the local pregnant population for Chlamydia trachomatis, Mycoplasma hominis, Ureaplasma urealyticum or asymptomatic bacteriuria on a routine basis in the future.

\subsection{Outline of the thesis}

After the general introduction and the objectives of the present study, presented in this chapter, a comprehensive review of the literature regarding the history and biology of Chlamydia trachomatis, Mycoplasma hominis, Ureaplasma urealyticum and asymptomatic bacteriuria is represented in chapter 2 . The relevant literature regarding their prevalence among pregnant women and associations between their presence and preterm birth or small-for-date born children is extensively reviewed.

Chapter 3 is divided into three parts. The first part describes the study design, including the study population, eligibility criteria, aims and 
procedures of the study, recorded demographic and pregnancy outcome data, and the definitions used. The second part describes the clinical and laboratory methods and materials used. The final paragraph outlines the model chosen for analysis of the data obtained, and the consecutive steps in the statistical analysis.

Chapter 4 reports on the results of the study. In the first section, the size, the epidemiological characteristics, and the outcome of pregnancy of the study group are described. In the second section, the detected prevalences of the micro-organisms studied and of asymptomatic bacteriuria are presented. Associations are presented between the presence of Chlamydia trachomatis, Mycoplasma hominis, Ureaplasma urealyricum, asymptomatic bacteriuria and both preterm birth and gestational age at delivery. Similarly, the associations are described between maternal demographic, behavioural and medical variables and these two outcomes of pregnancy.

In the summary and discussion in chapter 5 , the results of the study are evaluated against the background of the existing literature. Also specific problems encountered in this study are discussed. Recommendations for further investigation are formulated.

\section{Literature}

1. Eastman N.T. 1947. Prematurity from the viewpoint of the obstetrician. Am.Pract. 1:343-347.

2. Hoffman H.I., Bakketeig L.S. 1984. Risk factors associated with the occurrence of preterm birth. Clin.

Obstet. Gynecol 27:531-552.

3. McCormick M.C. 1985. The contribution of low birth weight to infant and childhood morbidity.

N.Engl.J.Med. 312:82-90.

4. Martin D.H., Koutsky L. et al. 1982. Prematurity and perinatal mortality in pregnancies complicated by matemal Chlamydia trachomatis infections.

J.Am.Med.Assoc. 247:1585-1588.

5. Harrison H.R., Alexander E.R. et al. 1983. Cerwical Chlamydia rachomatis and mycoplasmal infections in pregnancy: Epidemiology and outcomes. J.Am.Med.Assoc. 250:17211727.

6. Hardy P.H., Hardy J.B. et al. 1984. Prevalence of six sexually transmitted disease agents among pregnant inner-city adolescents and pregrancy outcome. Lancet 2:333-338.

7. MeGregor J., French J. et al. 1984. Randomized, prospective doublc-blinded trial of erythromycin base in idiopathic preterm labour. In: Proceedings of the Interscience Conference on Antimicrobial Agents and Chemotherapy. pp. 28-29. 
8. Elder H.A., Santamaria B.A. et al. 1971. The natural history of asymptomatic bacteriuria during pregnancy: the effect of tetracycline on the clinical course and outcome of pregnancy.

An J.Obstet.Gynecol. 111:441-445.

9. Minkoff H. 1983. Premarurity: infection as an etiologic factor.

Obstet.Gynecol $62: 137-144$.

10. Kass E.H. 1960. The role of asymptomatic bacteriuria in the pathogenesis of pyelonephritis. In Quin E.L., Kass E.H. (eds.) Biology of pyelonephritis. ILitte Brown Boston pp. 399-412.

11. Kincaid-Smith P., Bullen M. 1965. Bacteriuria in pregnancy. Lancet 1:395-399.

12. Naeye R.L. 1979. Causes of the excessive rates of perinatal mortality and prematurity in pregnancies complicated by maternal urinary tract infections. N.Engl.I.Med. 300:819-823. 


\section{Review of the literature}

\subsection{Chlamydia trachomatis}

\subsubsection{History}

Trachoma, an infectious keratoconjunctivitis due to chlamydial infection, was one of the earliest recognized clinical entities. References to it have been noted in Egyptian papyri and in Greco-Roman medical treatises. In northern Europe, trachoma was unknown until the Middle Ages, when it was disseminated by the Crusaders returning from Palestine. During and after the Napoleonic Wars, it became highly prevalent in the civilian and military populations and caused a considerable amount of blindness. During the nineteenth and early twentieth centuries, trachoma was widespread in Europe, particularly in the Mediterranean area.

Today, trachoma is still a major cause of preventable blindness in developing countries, particularly in Africa and Asia. Over 6 million people are probably affected throughout the world. The blinding severity of trachoma is a community problem that results from repeated eye-to-eye reinfection with Chlamydia trachomatis, along with the vertical transmission of the bacteria during birth.

The causal agent of trachoma was identified by Halberstaedter and von Prowazek $[1,2]$ in two much quoted papers published over 80 years ago. The first laboratory evidence of an infective agent of trachoma was their demonstration that scrapings from a trachomatous eye could produce subclinical to mild conjunctivitis in orang-outangs and that cytological examination of conjunctival scrapings from both natural and experimental hosts revealed the presence of "Zelleinschluisse" (cell inclu" sions) with varying morphology. During the next few years, Lindner and Halberstaedter together with von Prowazek described similar inclusions in conjunctival scrapings from infants with non-gonococcal ophthalmia neonatorum and in cervical and urethral specimens from their parents. They demonstrated that apart from the relationship between neonatal ocular and maternal genital infections, the agent was sexually transmissible.

Further research into the biology of the micro-organism was hampered by the lack of a suitable culture technique. In the late fifties, after the successful isolation and demonstration of the growth of the causal agent 
of trachoma on the yolk-sacs of incubated hen's eggs by T'ang and his colleagues [3] in China, there was an enormous increase in the knowledge of this agent. The next impulse on the epidemiological and biological research of Chlamydia trachomatis was given in the beginning of the sixties when Chlamydia trachomatis cultures on a continuous cell line were introduced [4]. The real explosion of knowledge and interest in Chlamydia trachomatis, however, has been in the last decade.

At present; it is clear that Chlamydia trachomatis is one of the most prevalent infectious organisms. Causal relationships have long been known between Chlamydia trachomatis and eye infections, and modern data point to associations with genital infections and infections of the newborn.

\subsubsection{Biology}

The genus Chlamydia is a bacterium which is an obligatory intracellular parasite, dependant upon the host cell for its energy. There are currently two species described: Chlamydia trachomatis, which is associated with human disease and Chlamydia psittaci which is associated with animal diseases. Chlamydia psittaci is rarely transferred to a human host. Recently however, a novel Chlamydia psittaci strain, designated TWAR, has been shown probably to be an important respiratory pathogen [5]. It has been isolated from individuals with acute respiratory disease including pneumonia, bronchitis and pharyngitis.

Members of the genus Chlamydia are obligate intracellular parasites and were once believed to be large viruses. However, they are bacteria because they possess both RNA and DNA, they have a discrete cell wall similar to that of Gram-negative bacteria, they multiply in host cells by binary fission and they are susceptible to several antibacterial agents.

\section{Replicative cycle}

The chlamydiae are distinguished from all other microorganisms by their unique growth cycle. The literature on the biology of chlamydiae is replete with descriptions of this developmental cycle, termed "the replicative cycle" [6-8].

In short, a small elementary body $(0.3 \mu \mathrm{m})$ with an electron-dense centre enters a host cell by endocytosis (a process analogous to phagocytosis) within a vacuole derived from the host cell membrane. Within about 1 hour metabolic changes lead the elementary body to reorganize into a larger $(1 \mu \mathrm{m})$ form called the initial body, which is less dense than the elementary body. Using the ATP-generating capacity of 
the host cell, the initial bodies divide by binary fission within the endocytic vacuole. After 24-72 hours, the initial bodies reorganize and condense to yield multiple elementary bodies, with the capacity to infect other host cells when the infected cell ruptures. Chlamydia trachomatis next synthesizes large amounts of glycogen, which surrounds the chlamydial cells within the endocytic vacuole. This structure is called an inclusion body, because after staining it is visible microscopically as a defined structure that may displace the nucleus of the host cell.

\section{Species}

The two species, Chlamydia trachomatis and Chlamydia psitraci, are differentiated on the bases of sulphonamide sensitivity and the presence of iodine-staining material in the cell inclusion. Chlamydia trachomatis is sulphonamide sensitive and iodine positive, while Chlamydia psittaci is sulphonamide resistant and iodine negative.

Chlamydiae do not produce metabolic energy and thus they parasitize the energy-producing systems of the host cell. Both chlamydial species share a common heat stable group antigen which appears to be associated with the cell wall. In addition, Chlamydia trachomatis possesses heat labile protein immuno subtypes.

\section{Antigenic structure}

Chlamydiae share common lipopolysaccharide antigens and specific cell wall protein antigens by which they are divided into a number of serotypes. The type-specific antigens are located on the surface of the infectious elementary bodies. The various major disease syndromes caused by chlamydiae are associated with different serotypes. Serotyping is performed by an immunofluorescence antibody procedure.

Until now, 15 separate immunotypes of Chlamydia trachomatis have been identified, lettered as $A, B, B a, C, D, E, F, G, H, I, J, K$ and $L_{1}, L_{2}$ and L3.

Chlamydia trachomatis is pathogenic for man and it manifests itself in three ways.

1. The well-known eye disease, trachoma, is due to Chlamydia trachomatis immunotypes $\mathrm{A}, \mathrm{B}, \mathrm{Ba}$ and $\mathrm{C}$.

2. The prevalent genital types of Chlamydia trachomatis are immunotypes $\mathrm{D}, \mathrm{E}, \mathrm{F}, \mathrm{G}, \mathrm{H}, \mathrm{I}, \mathrm{J}$ and $\mathrm{K}$.

3. Immunotypes $L_{1}, L_{2}$ and $L_{3}$ have been implicated in lymphogranuloma venereum.

Chlamydia psittaci is pathogenic mostly for birds and cattle, but occasionally affects a human with a very severe form of pneumonia: psittacosis. 


\section{Susceptibility}

Chlamydiate are highly susceptible to environmental conditions and survive only briefly outside the body. Thus, transmission requires close body contact or in the case of Chlamydia psittaci, rapid spread by dust or droplets. They are susceptible to a considerable range of antimicrobial agents, of which the tetracyclines have been the most effective agents in clinical practice. In contrast to Chlamydia psittaci, strains of Chlamydia trachomatis are sensitive to sulphonamides; this finding indicates that Chlamydia trachomatis synthesizes its own folic acid, whereas Chlamydia psittaci uses that of the host.

\subsubsection{Prevalence in non-pregnant women}

Chlamydia trachomatis has emerged as the most common sexually transmitted bacterial pathogen in some centres. The highest rates of isolation of Chlamydia trachomatis from women have been found in clinics for sexually transmitted diseases. Isolation rates as high as $37 \%$ have been described [9]. Cervical infection with Chlamydia trachomatis is two to three times more common than gonorrhoea [10]. In primary care practices, the frequency of Chlamydia trachomatis infection has been reported to be between $4 \%$ and $9 \%[11,12]$ and has reached $8 \%$ to $9 \%$ of women attending general gynaecology clinics [9]. The organism has been isolated from $4.6 \%$ of American female college students attending a university gynaecology clinic [13]. The frequency in other settings is higher: $6 \%$ to $23 \%$ in family planning clinics [14]; $8 \%$ to $26 \%$ in clinics for adolescents; and $20 \%$ to $30 \%$ in clinics for patients with sexually transmitted diseases [15]. Recently, a relatively high isolation rate of Chlamydia trachomatis was detected in the cervix of postmenopausal women [16], indicating that the infection may reside intracellularly for long periods of time. In the Netherlands, cervical Chlamydia trachomatis was detected in $5.5 \%$ of 197 women attending the Groningen University Hospital out-patient department for birth control advice [43]. In these women, promiscuity (defined as more than one sexual partner during the preceding year) was found to be significantly correlated with chlamydial infection. In the Rotterdam STD clinic, positive cultures for Chlamydia trachomatis were found in $10 \%$ of 351 women [42]. The population examined consisted of prostitutes as well as non-prostitutes. Table 2.1 summarizes the prevalences reported from various centres. 
Table 2.1

Prevalence of Chlamydia trachomutis in non-pregnant women.

\begin{tabular}{lllll}
\hline Population type & Country & $\%$ & Ref: & Year \\
\hline Postmenopausal women & Japan & 3 & {$[16]$} & 1987 \\
University gynaecological clinic & USA & $4-5$ & {$[13]$} & 1979 \\
General gynaecological clinic & USA & $8-9$ & {$[9]$} & 1980 \\
Primary care practice & USA & $4-9$ & {$[11]$} & 1982 \\
Family practice & USA & 6 & {$[12]$} & 1984 \\
Family planning clinic & USA & $6-23$ & {$[14]$} & 1983 \\
Adolescents clinic & USA & $8-26$ & {$[15]$} & 1985 \\
University gynaecological clinic & Netherlands & 5 & {$[43]$} & 1988 \\
STD clinic & Netherlands & 10 & {$[42]$} & 1988 \\
STD clinics & USA & $20-37$ & {$[9]$} & 1980 \\
\hline
\end{tabular}

\subsubsection{Prevalence in pregnant women}

During the past eight years, there have been several studies of pregnant populations of antenatal clinics, mainly in the United States and in Northern Europe (particularly Sweden). Figures obtained from these studies may not be entirely representative for the different districts of the Netherlands. Especially in the USA, antenatal clinics are often for the underprivileged minorities in society and most women attend private practitioners. This inevitably results in a selection of the population. Also, the gestational age at enrollment varies, ranging from the first antenatal visit to the postpartum period.

The infection is clinically more difficult to recognize in pregnant than in non-pregnant women. Pregnant women usually have increased waginal discharge, their endocervical mucus frequently has a cloudy ap pearance, and their Gram-stained endocervical smears often show an increased number of leukocytes. These findings also are associated with cervicitis due to a chlamydial infection.

Table 2.2 shows the prevalences of cervical Chlamydia trachomatis in pregnant women reported by various authors.

The first prospective studies of chlamydial infection in pregnancy defined the risk of infection for infants delivered vaginally to mothers infected with Chlamydia trachomatis [17]. Depending on the population examined, the prevalence of cervical infection with Chlamydia trachomatis has been demonstrated in $0 \%$ to $30 \%$ of pregnant women attending antenatal clinics. A high isolation percentage of Chlamydia trachomatis is often associated with a low socio-economic status of the 
Prevalence of cervical Chlamydia trachomatis in pregnant women.

\begin{tabular}{llcccc}
\hline $\begin{array}{l}\text { Country } \\
\text { (weeks) }\end{array}$ & $\begin{array}{l}\text { State of pregnancy } \\
\text { size }\end{array}$ & $\begin{array}{c}\text { Sample } \\
\text { positive }\end{array}$ & Percentage & Ref. & Year \\
\hline USA & $<11$ & 560 & 0.5 & {$[22]$} & 1987 \\
USA & earlly & 4218 & 3.7 & {$[41]$} & 1982 \\
USA & throughout5 & 531 & 4.7 & {$[37]$} & 1986 \\
USA & $1^{\text {st }}+3^{\text {rd }}$ trimester & 6864 & 4.7 & {$[31]$} & 1987 \\
USA & early & 112 & 5.4 & {$[38]$} & 1975 \\
USA & $<19$ & 268 & 6.7 & {$[26]$} & 1982 \\
USA & througluout & 1125 & 6.9 & {$[23]$} & 1982 \\
USA & throughout & 1365 & 8 & {$[27]$} & 1983 \\
USA & $>18$ & 534 & 9 & {$[30]$} & 1986 \\
USA & throughout & 2311 & 2.1 & {$[35]$} & 1987 \\
USA & $<24$ & 1152 & 22 & {$[36]$} & 1987 \\
UK & throughout & 107 & 0 & {$[40]$} & 1981 \\
Sweden & puerperal & 1328 & 2.4 & {$[21]$} & 1981 \\
Netherlands & throughout & 304 & 7.9 & {$[34]$} & 1987 \\
Sweden & puerperal & 273 & 7.4 & {$[39]$} & 1980 \\
Phillippines & throughout & 3631 & 6.8 & {$[20]$} & 1985 \\
Alaska & throughout & 115 & 30 & {$[19]$} & 1987 \\
& & & & & \\
\hline
\end{tabular}

patient. The highest prevalences were found in an unselected population of American Navajo Indian women [18] and in an geographically isolated and remote community of Inupiaq Eskimos in northwest Alaska [19]. In the latter population, Chlamydia trachomatis was identified in $23 \%$, including $39 \%$ of teenagers, $30 \%$ of pregnant patients, $47 \%$ of pregnant teenagers and $40 \%$ of women with pelvic inflammatory disease. In the urban areas of Manilla, the Philippines, the overall percentage among pregnant women of low socio-economic status approaches $17 \%$. The incidence of infection ranged from $18.4 \%$ in the group aged 15 to 19 through $13 \%$ in the group aged 30 to 39 , to $0 \%$ in the 40 and older group [20].

The pregnant woman with chlamydial infection is most likely to be younger than uninfected women in the same population. Many authors have reported an inverse relationship of isolation of Chlamydia trachomatis to age. In Sweden the isolation rates range from $7.1 \%$ of women under 19 years of age to $0.5 \%$ in women 30 years of age and older [21]. The last percentage is consistent with the isolation percentage found among patients undergoing chorionic villus sampling in the United 
States [22]. The rates of chlamydial infection have also been found to be higher in primigravidae. This finding may be a reflection of age, assuming that older women have had more pregnancies.

The reasons why the rate of chlamydiall infection among pregnant women appears to decrease with increasing age are not clear. The comparatively lower rate of chlamydial infection in the older women might imply that chlamydial infection is self-limited. However no studies are available in which untreated infected women are cultured during several years. A plausible explanation would be the assumption that the lower rate in the older pregnant women is a result of tubal infertility, caused by Chlamydia trachomatis.

In studies conducted in the United States, race was also an important factor affecting the rates of isolation of Chlamydia trachomatis from pregnant women. Chiamydia trachomatis was more frequently isolated from Black and Hispanic women than from Caucasian women [23].

\subsubsection{Association between prematurity and the presence of maternal Chlamydia trachomatis}

Preterm delivery has been associated with maternal genital infections, most commonly with Neisseria gonorrhoeae [24] and group B streptococci [25]. The role of Chlamydia trachomatis has only recently been examined, since the techniques for diagnosing Chlamydia trachomatis infections have become more widely available. Only a limited number of studies have examined women in early pregnancy and determined the association between the infection and outcome. Essentially, two types of study design have been employed, i.e. cohort studies and case-control studies. In cohort studies groups of patients with and without a particular micro-organism are followed during pregnancy, whereas in casecontrol studies the prevalence of a micro-organism of interest in patients with a certain (e.g. adverse) pregnancy outcome is compared with the prevalence of that micro-organism in a control group of patients with another (e.g. favourable) pregnancy outcome.

The reason why infection leads to (preterm) rupture of membranes in some cases and to (preterm) labour in others remains to be answered. Nevertheless, since preterm rupture of membranes and preterm labour can be considered as two sides of the same coin (e.g. prematurity), they will be discussed together.

Martin and others, in a small cohort study, first demonstrated an association between prematurity and cervical colonization with Chlamydia trachomatis [26]. They obtained cervical cultures from 268 women enrolling for antenatal care before the 19 th week of gestation. Eighteen 
women $(6.7 \%)$ had a positive culture. The incidence of premanurity ( $<37$ weeks of gestation) was significantly higher in women with positive cultures than in women with negative cultures $(27.8 \%$ versus $6.3 \%$, $\mathrm{p}=0.0048$ ). A positive culture was associated with a relative risk for prenaturity of 4.5 . Furthermore, the incidence of extreme prematurity ( 630 weeks of gestation) was $27.7 \%(5 / 18)$ in women with positive cultures and $2.5 \%(6 / 238)$ in women with negative cultures $(p<0.001)$. Harrison et al. conducted a prospective cohort study and found an $8 \%$ prevalence of positive cervical cultures in 1.365 women [27]. The relationship between the presence of Chlamydia trachomatis in the cervix and prematurity was studied in a subset of 606 women who presented for antenatal care at or before the 24 th week of pregnancy. Although the incidence of prematurity in women with and without Chlamydia trachomatis was not clearly stated, the authors stated that no difference could be demonstrated. IgM chlamydial antibodies were measured in the sera of seventy-two of the ninety-five patients with positive cervical cultures. Rupture of membranes (term plus preterm) was more common in IgM positive women (41.1\% versus $7.5 \%$ ) than in IgM negative women ( $p<0.01)$. The authors suggested that only IgMseropositive patients with Chlamydia trachomatis were at increased risk of preterm rupture of membranes. This would implicate that only the subset of women with recently acquired Chlamydia trachomatis infection, is at risk for premature events. The relationship between $\operatorname{Ig} \mathrm{M}$ status of the mother and prematurity was not reported.

Ross et al. compared the rate of Chlamydia trachomatis isolation from the cervix and the incidence of chlamydial antibodies in sera and cervical secretions from women in preterm labour with intact membranes with those from a control group [28]. While Chlamydia trachomatis was not isolated from any of the cervical specimens investigated, chlamydial antibodies were detected more commonly in matemal blood $(20.8 \%$ versus $3.6 \%, p=0.01)$, and cervical secretions $(18.2 \%$ versus $3.6 \%, \mathrm{p}=0.003)$ from women in preterm labour than from women in the control group.

Lamont el al. compared the prevalence of positive cervical cultures in 72 women with spontaneous preterm labour (26-33 completed weeks of pregnancy) to a control group of 26 women who were not in labour and underwent caesarean section at a similar gestational age [29]. There were five patients with positive chlamydia cultures in the study group and none in the control group.

Gravett and associates cultured the cerwix of 534 pregnant women in the second and third trimesters (mean gestational age at the time of enrollment of 32.6 weeks) [30]. A positive culture was significantly associated with preterm labour occurring before 34 weeks (odds ratio: 4.0 , $\mathrm{p}<0.01$ ) and preterm labour occuring before 37 weeks (odds ratio: 4.3 , 
$\mathrm{p}<0.01)$. A positive culture was also associated with preterm rupture of membranes (odds ratio: $2.4 \mathrm{p}<0.05$ ) and a birth weight below $2500 \mathrm{~g}$ (odds ratio: $2.7, \mathrm{p}<0.01$ ). The risk for these adverse pregnancy outcomes was not increased by the simultaneous presence of bacterial vaginosis. Since birth weight was not related to the gestational age in this study, no data are available on the possible association of matemal Chlamydia trachomatis and small-for-date infants.

In a recent large cohort study Sweet et al, obtained cervical cultures for Chlamydia trachomatis from 6864 women at the time of the initial antenatal visit [31]. Cultures were repeated at 30-34 weeks of gestation. A subset of this population ( $\mathrm{n}=3293$ ) was also cultured for Neisseria gonorrhoeae, group B streptococci, Mycoplasma hominis, and Ureaplasma urealyticum. Chlamydia rachomatis was recovered from $4.7 \%$ (322/6864). Only 270 patients with positive Chlamydia trachomatis cultures were evaluated. Patients with positive Chlamydia trachomatis cultures did not have a higher incidence of preterm delivery ( $<37$ weeks of gestation) or preterm rupture of membranes than women with negative Chlamydia trachomatis cultures (preterm delivery $10.7 \%$ versus $9.6 \%$, not significant and for preterm rupture of membranes $10.3 \%$ versus $9.6 \%$, not significant). Rupture of membranes associated with preterm delivery was more common in women with positive than in women with negative Chlamydia trachomatis cultures $(54.5 \%$ versus $27.7 \%, \mathrm{p}=0.003$ ). A positive cervical culture for Chlamydia trachomatis was associated with a relative risk of 2 for rupture of membranes and preterm delivery, although the attributable risk was $9 \%$. Colonized women with positive maternal serum IgM (defined as a titre 1:32 or higher) had a higher incidence of preterm delivery (19\% versus $13.1 \%$ ) and preterm rupture of membranes $(19 \%$ versus $8 \%, p=0.03)$ than colonized women with negative IgM. When women with positive IgM were matched with women with negative Chlamydia trachomatis cultures, the only significant finding was a higher incidence of preterm delivery ( $19.4 \%$ versus $4.5 \%, p=0.02)$. A positive IgM titre was associated with a relative risk of 4.3 and an attributable risk of $67 \%$. Therefore, most of the excess in preterm rupture of membranes and preterm delivery associated with Chlamydia trachomatis was in women who had IgM present.

Martius et al. reported the results of a case-control study in which the rates of bacterial vaginosis (defined by a Gram stain of vaginal fluid), cervical Chlamydia trachomatis, Mycoplasma hominis, and Ureaplasma urealyticum colonization were compared in 97 women in premature labour (with and without rupture of membranes) with the rates in a control group of 115 women who delivered at term [32]. Women in preterm labour were subdivided into two groups: 61 women had a premature delivery before the 37 th week, and in the remaining 36 
patients, the pregnancy continued to term. Women with preterm labour delivering before 37 weeks were more likely to have a positive culture for Chlamydia trachomatis (odds ratio: 5.4, $p<0.02$ ) than women examined at term. Additionally, a higher prevalence of bacterial vaginosis and a lower colonization rate with Lactobacillus species (odds ratio: $0.2, p=0.002$ ) was detected in women delivering before 37 weeks of pregnancy.

In a case-control study Alger et al. compared the relative prevalence of endocervical infection with Chlamydia trachomatis and group B streptococci in patients with preterm rupture of membranes (20-37 weeks of pregnancy) versus the prevalence of these micro-organisms in patients with spontaneously ruptured membranes after the $37^{\text {th }}$ week of gestation [33]. Chlamydia trachomatis was isolated from $44 \%$ (23/52) patients with preterm rupture of membranes versus $15 \%(13 / 84)$ women in the control group $(\mathrm{p}<0.001)$. The association between cervical Chlamydia trachomatis and the risk of preterm rupture of membranes was independent of the presence of Neisseria gonorrhoeae and group B streptococci.

Table 2.3 depicts the reported association of the studies.

Table 2.3

Reported presence and absence of association between maternal cervical Chlamydia trachomatis and prematurity.

\begin{tabular}{llll}
\hline Study design & Association & Reference & Year \\
\hline cohort & + & {$[26]$} & 1982 \\
cohort & none & {$[27]$} & 1983 \\
cohort & + & {$[30]$} & 1986 \\
cohort & nonc & {$[31]$} & 1987 \\
case-control & none & {$[28]$} & 1984 \\
case-control & $?$ & {$[29]$} & 1986 \\
case-control & + & {$[32]$} & 1988 \\
case-control & + & {$[33]$} & 1988 \\
\hline
\end{tabular}

In conclusion, of the four reported cohort studies, two support and two deny an association between cervical Chlamydia trachomatis infection and prematurity. Results from the four case-control studies reviewed above are conflicting (one was negative, two were positive, and the other inconclusive). The inconsistency between different studies raises 
uncertainty as to whether or not Chamydia trachomatis is related to prematurity. The suggested association between the presence of Chlamydia trachomatis and preterm birth seem to vary with the population studied. Randomized trials of treatment have not been reported.

2.1.6 Association between small-for-date children and the presence of maternal Chlamydia trachomatis

No study is currently available which adequately investigates any association between small-for-date children and the presence of maternal Chlamydia trachomatis infection. Many studies of differences in pregnancy outcome have assigned all low birth weight infants (often defined as those with a birth weight of $<2500 \mathrm{~g}$ ) to a single group, despite the fact that there are actually two subgroups of such infants i.e. those who are born prematurely and those who are small for gestational age. It is possible, of course, for an infant to belong to both groups. The implications from an association between colonization of the genital tract and birth of a small-for-date child are different from those derived from an association with preterm delivery of an infant adequate for gestational age.

Berman et al. conducted a prospective cohort study in a homogeneous sample of 1204 pregnant women with a high prevalence of Chlamydia trachomatis [36]. Cervical cultures and serum samples for IgG and IgM were obtained before the 24th week of gestation. Chlamydia trachomatis was present in $22 \%$ (251/1152) of the patients cultured. Among the women found to have Chlamydia trachomatis on culture, $89 \%$ (181/204) had a positive titre for IgG whereas only 5\% (10/204) had a positive IgM titre (positive if titre was $1: 32$ or higher). There was no association between cervical Chlamydia trachomatis and low bith weight. The authors suggest that a possible explanation might be the chronic state of infection in the majority of the culture-positive women. In a subset of seventy-two of their ninety-five patients with positive cervical cultures, Harrison et al. determined also maternal serum $\operatorname{lgM}$ antichlamydial antibody titres [27]. Positive serology (IgM titres above 1:32 to 1:64) was detected in 17 women, and four of them delivered low birth weight neonates. Of the remaining 53 patients with negative $\operatorname{IgM}$ titres, one had a low birth weight infant $(p<0.02)$. The authors suggested that only IgM-seropositive patients with Chlamydia trachomatis were at increased risk of low neonatal birth weight. This would imply that only the subset of women with recently acquired Chlamydia trachomatis infection are at risk for delivering infants too small for the gestational 
age. However, the results of this study should be interpreted with great care since low birth weight was not defined, nor was it related to the duration of pregnancy.

In a subser of their screened pregnant population, Sweet et al. matched Chlamydia trachomatis-positive cases $(\mathrm{n}=270)$ against Chlamydia trachomatis-negative controls $(n=270)$ [31]. There was no significant difference in the incidence of the birth weights small-for-gestational-age (14.8\% versus $12.6 \%$ ).

In the study already mentioned above, Gravett et al. found an association of maternal cervical Chlamydia trachomatis and a birth weight $<2500 \mathrm{~g}$ ( $\mathrm{p}=0.01$ odds ratio: 2.7 ) [30]. However, since birth weight was not related to the gestational age in this study, no data are available on the possible association of maternal Chlamydia trachomatis and smallfor-dates.

The results of the above reviewed studies are summarized in Table 2.4

Table 2.4

Possible association between matemal cervical Chlamydia trachomatis and smallfor dates.

\begin{tabular}{llll}
\hline Study design & Association & Reference & Year \\
\hline cohort & none & {$[36]$} & 1987 \\
cohort & + & {$[30]$} & 1986 \\
case-control & none & {$[31]$} & 1987 \\
cohort & + & {$[27]$} & 1983 \\
\hline
\end{tabular}

In conclusion, studies reporting an association between small-for-date children and the presence of maternal Chlamydia trachomatis all failed to assess birth weight in relation to the length of gestation. Moreover, no adjustments were made for parity of the mother and sex of the infant. In two of the three cohort studies reviewed, a positive association was suggested; the one case-control study denied any association. 


\subsection{Mycoplasma hominis and Ureaplasma urealyticum}

\subsubsection{History}

Mycoplasma organisms were first isolated in man in 1937 from an abscess of Bartholin"s gland [44]. Since then, there has been increasing interest in determining the role of these agents in diseases of man, particularly in the pathogenesis of genital tract infections. "The fact that mycoplasma infections are known to cause reproductive problems in other mammals $[45,46]$ and that some mycoplasma species can cause infections in man has led to the hypothesis that genital tract colonization may contribute to human infertility and fetal loss [47]. On the other hand, the high rate of colonization in men and women of reproductive age makes it very likely that these agents should be considered as commensals. Therefore, a pathogenic role of these micro-organisms will be difficult to establish. In the next paragraph, the commensal versus the pathogenic status of these organisms in pregnancy will be discussed.

\subsubsection{Biology}

Mycoplasmata are widely distributed in nature as parasites of man, animals, arthropods and plants. In man they have been found to be common inhabitants of the oropharyngeal and genital mucous membranes.

The term "Mycoplasma" has been used loosely to clescribe all the self-replicating prokaryotes that lack a cell wall. These organisms, once referred to as pleuropneumonia-like organisms (PPLO), form the taxonomic class Mollicutes. They are the smallest and simplest self-replicating prokaryotes known today. All mollicutes organisms have a trilaminar cell membrane similar to that of eukaryotes, but they lack a cell wall. They are surrounded by a plasma membrane only and contain both ribosomal ribonucleic acid and double-stranded deoxyribonucleic acid. The molecular biology and genetics of mycoplasmata have been reviewed in a recent in-depth article by Razin [48].

The genus Mycoplasma comprises more than 60 species, including all the human parasitic Mollicutes except the genus Ureaplasma, which has a single species, urealyticum. Ureaplasma urealyticum has been separated from the genus Mycoplasma because of its distinclive capacity to hydrolyse urea. Ureaplasma was originally termed $\mathrm{T}$-strain or T-mycoplasmata ( $T$ for tiny) because it produces very small colonies 
(15 to $30 \mu \mathrm{m}$ in diameter) on agar medium. Colonies of Mycoplasma hominis are 200 to $300 \mu \mathrm{m}$ in diameter and have a dense centre that gives them a characteristic "fried egg" appearance.

The so-called genital mycoplasmata include Mycoplasma hominis, Mycoplasma genitalium, Mycoplasma fermentans and Ureaplasma urealyticum. Mycoplasma hominis and Ureaplasma urealyticum are regarded as the primary genital Mollicutes species because they can be isolated from the mucosa of the human genital tract in considerable frequency. They are restricted to humans and vertebrates only. Since Mycoplasma genitalium and Mycoplasma fermentans have only been isolated very rarely from the genital tract, adequate study of their potential as pathogens is difficult to establish.

In the lower genital tract of healthy, sexually active women, $M y c o p l a s-$ ma hominis and Ureaplasma urealyticum may be recovered from the peri-urethral area, the vaginal wall, the posterior fornix and the endocervix [49]. Unlike chlamydiae, they do not have a predilection for columnar epithelium.

\subsubsection{Prevalence in non-pregnant women}

It seems likely that infants become colonized with genital mycoplasmata during passage through the birth canal because infants delivered by caesarean section are colonized less often than those delivered vaginally $[50]$. Ureaplasmata have been isolated from the genitalia of up to one third of infant girls and from a smaller proportion of infant boys. There is a progressive decrease with age in the proportion of infants who are colonized. Genital mycoplasmata are seldom recovered from urine or genital specimens from prepubertal boys, whereas between 9 and 22 per cent of prepubertal girls have been found to be colonized with Ureaplasma urealyticum and 8 per cent with Mycoplasma hominis. After puberty, in both sexes the frequency of colonization of the lower genital tract depends on a variety of factors. The most important factor is sexual experience followed by the number of sexual partners. The colonization rate increases with the number of sexual partners. McCormack et al. [51] isolated Mycoplasma hominis from the vagina of less than $2 \%$ of sexually mature young women without a history of sexual contact and Ureaplasma urealyticum from less than $6 \%$. However, in women who have had intercourse with three or more partners, $M y$ coplasma hominis and Ureaplasma urealyticum were isolated in $1.7 \%$ and $75 \%$ respectively. Virgin adult men seldom carry either Mycoplasma hominis or Ureaplasma urealyticum, whereas over $50 \%$ of males who have multiple partners may be culture positive. The extent to which genital mycoplasmata in women persist in the absence of re-coloniza- 
tion is difficult to assess. Because of repeated sexual contact, persistence may be more apparent than real. Although randomly selected populations have not been studied, it appears that colonization with Mycoplasma hominis and Ureaplasma urealyticum decreases after the menopause [52]. Overall, the frequency of Mycoplasma hominis colonization is considerably lower than that of Ureaplasma urealyticum in all phases of life in both sexes.

\subsubsection{Prevalence in pregnant women}

Mårdh and Weström [52] were the first to suggest that the hormonal status of the individual might play an important role in the occurrence of Ureaplasma urealyticum. This was based on the observation that Ureaplasma urealyticum was isolated more frequently from pregnant women compared to sexually mature non-pregnant women. The highest incidence was found in the late gestational stage $[52,53,56]$. Prepubertal girls and postmenopausal women had a low prevalence of this organism [52-54]. They suggested that the serum level of oestrogen or progesterone (or both) is an important factor for the occurrence of Ureaplasma urealyticum in the female genital tract. Low serum concentrations of both oestrogen and progesterone are common factors in the three age groups with a low incidence of this organism i.e. neonates, prepubertal girls and postmenopausal women. Further support for the hypothesis of Mårdh and Weström comes from studies by Furr and Taylor-Robinson, who have shown that experimental colonization of the vagina of mice with Mycoplasma pulmonis was enhanced greatly by progesterone treatment [55].

The reported prevalences of Mycoplasma hominis and of Ureaplasma urealyticum in pregnant women in the studies reviewed are presented in Table 2.5.

In conclusion, both Mycoplasma hominis and Ureaplasma urealyticum can be isolated with considerable frequency from the genital tract of healthy adult women. Most investigators have found the highest isolation rates of genital colonization in women during pregnancy. 
Table 2.5

Prevallence of cervico-vaginal Mycoplasma hominis and Ureaplasma urealyticum in pregnant wornen.

\begin{tabular}{lrllll}
\hline $\begin{array}{l}\text { State of } \\
\text { pregnancy }\end{array}$ & $\begin{array}{l}\text { Sample } \\
\text { size }\end{array}$ & $\begin{array}{l}\text { Mycoplasma } \\
\text { hominis } \%\end{array}$ & $\begin{array}{l}\text { Ureaplasma } \\
\text { urealyticum } \%\end{array}$ & Ref. & Year \\
\hline $\begin{array}{l}\text { throughout } \\
1^{\text {st }} \text { wisit }\end{array}$ & 162 & 5.3 & 43.8 & {$[56]$} & 1981 \\
$1^{\text {st }}$ trimester & 199 & 10 & 48 & {$[68]$} & 1979 \\
throughout $^{\text {st }}$ & 1365 & 23.5 & 58.2 & {$[67]$} & 1970 \\
$1^{\text {st }}$ visit & 233 & 39.9 & 65.2 & {$[65]$} & 1986 \\
\hline
\end{tabular}

2.2.5 Association between the presence of maternal Mycoplasma hominis and Ureaplasma urealyticum and prematurity

Genitall pathogens, notably the genital mycoplasmata, have been implicated as causes of prematurity. Case control studies, cohort studies, and randomized clinical therapeutic trials have been used to investigate the relationship between mycoplasma species and prematurity.

Ross et al. cultured the cervix of 162 women with singleton pregnancies on three occasions during gestation and once postpartum [56]. The overall isolation rate of Ureaplasma urealyticum was $43 \%$, while that of Mycoplasma hominis was $5.3 \%$. The mean gestational age of women colonized with only Ureaplasma urealyticum was slightly greater than that of non-colonized women $(40.5 \pm 1.14$ weeks versus $39.9 \pm 1.57$ weeks). No significant association between the isolation of $M y$ coplasma hominis and gestational age was found.

Minkoff et al. prospectively examined 233 patients at the time of the first antenatal visit (mean $13.8 \pm 3.6$ weeks) [57]. Positive vaginal cultures for Mycoplasma hominis were found in $39.9 \%$ and for Ureaplasma urealyticum in $65.2 \%$. A significant difference in the isolation rate of Ureaplasma urealyticum was observed in women with and without preterm labour ( $80 \%$ versus $61.2 \%, \mathrm{p}<0.05$ ). No significant difference was found in the colonization rate with Mycoplasma hominis ( $42.8 \%$ versus $35.5 \%)$ in these two groups. No association between colonization with mycoplasma species and premature rupture of the membranes was documented. In women with and without premature rupture of the membranes, Mycoplasma hominis was found in $52.5 \%$ and $35.1 \%$ respectively. However, Ureaplasma urealyticum was pre- 
sent in $67.5 \%$ of women with and $66.9 \%$ of women without premature rupture of the membranes. Also, no association was observed between low birth weight, premature delivery and mycoplasma species colonization.

Harrison et al. conducted a prospective cohort study and found $M y$ coplasma hominis in $23.5 \%$ and Ureaplasma urealyticum in $72.3 \%$ of the cervices of 1,365 women [65]. The relationship between the presence of mycoplasma organisms in the cervix and prematurity was studied in a subset of 606 women who presented for antenatal care at or before the $24^{\text {th }}$ week. Using multivariate analysis, they found that colonization with Mycoplasma hominis was not associated with prematurity. Interestingly, women colonized with Ureaplasma urealyticum had a decreased risk of prematurity. No association was found between colonization with either Mycoplasma hominis or Ureaplasma urealyticum and preterm or premature rupture of membranes.

Martius et al. reported the results of a case-control study in which the rate of isolation of Ureaplasma urealyticum and Mycoplasma hominis from the vagina of 97 women in premature labour (with and without premature rupture of membranes) was compared with a control group of 115 women who delivered at term [59]. No significant differences were found in the prevalence of Mycoplasma hominis or Ureaplasma urealyticum among women with preterm labour delivering before or after the $37^{\text {th }}$ week of gestation.

The associations found are summarized in Table 2.6.

Table 2.6

Possible association between the presence of maternal Mycoplasma hominis / U reaplasma urealyticum and prematurity.

\begin{tabular}{llll}
\hline Study design & $\begin{array}{l}\text { Association } \\
\text { M. hominis / U. urealyticum }\end{array}$ & Reference & Year \\
\hline cohort & none/positive & {$[56]$} & 1981 \\
cohort & none/positive & {$[57]$} & 1984 \\
cohort & none/negative & $165]$ & 1986 \\
case-control & none/none & {$[59]$} & 1988 \\
\hline
\end{tabular}


In summary, all the studies reviewed failed to show a positive association between cervico-vaginal colonization with Mycoplasma hominis and prematurity. In two out of the four studies a positive association between prematurity and the presence of maternal Ureaplasma ureabyticum was reported. However, in one study a decreased risk of premature birth in women colonized with Ureaplasma urealyticum was noted.

\subsubsection{Association between small-for-date children and the presence of} maternal Mycoplasma hominis and Ureaplasma urealyticum

Studies from the early seventies, (before its adverse effects on the fetus were recognized), showed that tetracycline treatment for six weeks during pregnancy resulted in a significant reduction of the birth rate of infants weighing $2500 \mathrm{~g}$ or less compared to a placebo group. It was postulated that tetracycline-sensitive micro-organisms might be responsible for this phenomenon and mycoplasmata were among those considered $[60]$. It is feasible that the organisms might cause chorioamnionitis in the لater stages of pregnancy which could result in impaired fetal nutrition or early labour or both. Also, histological evidence of chorio-amnionitis has been obtained in the placentas when the infants were colonized with Ureaplasma urealyticum [61].

The first direct evidence for an association between mycoplasmata and birth weight was obtained in a study by Klein et al [62]. In unselected newborn infants it was found that the rates of nasal or pharyngeal colonization with ureaplasmata were roughly inversely proportional to birth weight. Positive cultures were more common in low birth weight neonates ( $22 \%$ versus $12 \%, p=0.04$ ). An association between prolonged rupture of membranes and a higher colonization rate with mycoplasma species was detected in low birth weight infants. No data on gestational age, however, were presented and therefore the prevalence of mycoplasma organisms in preterm infants could not be established.

In a subsequent prospective study Braun et all. obtained urine and cervical specimens from 484 pregnant women at their first antenatal visit [63]. Mycoplasma hominis was isolated in $47 \%$ and Ureaplasma urealyticum in $79 \%$ of the women examined. Although the ureaplasma positive women gave birth to infants with a significantly lower mean birth weight $(3099 \mathrm{~g}$ versus $3297 \mathrm{~g}, \mathrm{p}<0.003$ ) than the ureaplasma negative group of women, the incidence of low birth weight infants in the two groups was not significantly different $(9.8 \%$ versus $4 \%$ ). Also, no difference was found in the incidence of low birth weight infants in women with and without colonization by Mycoplasma hominis $(10.4 \%$ versus $7 \%$ ). 
An interesting observation was made by Ross et al. [56]. They found that Caucasian women colonised by ureaplasmata had larger babies than those born to non-colonised women. This difference was not seen for babies born to Asian women. The authors speculated that the race and social class were more important than the ureaplasmata in affecting the size of the infant. No significant association was found between the isolation of Mycoplasma hominis and mean birth weight.

Upadhyaya et al. cultured the cervix of 135 women presenting for antenatal care with a gestational age of less than 20 weeks [64]. The prevalence of Ureaplasma urealyticum in this population was $44 \%$. No significant differences in the incidence of preterm delivery ( $<37$ weeks), mean gestational age, mean birth weight, low birth weight, and small for date neonates were found between women with positive and negative cultures for Ureaplasma urealyticum.

Harrison reported on the endocervical carriage of ureaplasmata and their possible association with abnormal pregnancy outcome in two large unselected groups of women studied prospectively [65]. Using univariate and conditional logistic regression analysis, ureaplasmata were not found to be associated either with spontaneous abortion, term or preterm low birth weight, postpartum endometritis or postpartum fever. He pointed out, however that an association might exist in subgroups of infected women and outlined the need and the difficulties of defining such subgroups.

Kass et al. conducted a double blind treatment trial of erythromycin in pregnant women with positive cultures for either Mycoplasma hominis or Ureaplasma urealyticum [66]. During the second or third trimester of

Table 2.7

Association between small-for-date infants and the presence of maternal Mycoplasma hominis / Ureaplasma wrealyticum

\begin{tabular}{llll}
\hline Study design & $\begin{array}{l}\text { Association } \\
\text { M. hominis / U. urealyticum }\end{array}$ & Reference & Year \\
\hline case-control & none / positive & {$[62]$} & 1983 \\
cohor & none/ ? & {$[63]$} & 1985 \\
cohort & none / none & {$[56]$} & 1987 \\
cohort & n.s. / none & {$[6]$} & 1987 \\
cohort & n.s. / ? & {$[65]$} & 1978 \\
treatment trial & none/ none & {$[66]$} & 1983 \\
\hline
\end{tabular}

n.s. not studied 
pregnancy, $250 \mathrm{mg}$ of erythromycin or a placebo were given four times daily for 6 weeks. Treatment during the second trimester had no effect on birth weight. However, women treated with erythromycin during the third trimester delivered infants with a greater mean birth weight $(3331 \mathrm{~g})$ than did women in the placebo group ( $3187 \mathrm{~g})$ and only 2 of 64 treated women delivered infants weighing less than $2500 \mathrm{~g}$ compared with 10 out of 84 in the placebo group.

In Table 2.7 the results of the reviewed studies are summarized.

In conclusion, the data available up to now are insufficient to conclude that genital mycoplasmata are directly responsible for low birth weight. Hardly any study addressing this issue detected a clear association between the presence of maternal genital mycoplasmata and small-fordates. It appears that different authors keep quoting each other in suggesting, rather than in really establishing, a direct association.

\subsection{Asymptomatic bacteriuria}

\subsubsection{Prevalence in pregnancy}

The prevalence of asymptomatic bacteriuria is approximately equal in both pregnant and non-pregnant women. Between $2 \%$ and $10 \%$ (mean $2 \%-4 \%$ ) of pregnant and non-pregnant women have symptomless or covert bacteriuria [69-72]. The prevalence depends on age, parity, and social class. The risk appears to be particularly increased in women with a previous history of urinary tract infection. Gram-negative organisms, especially Escherichia coli, account for the vast majority of pathogens isolated.

Asymptomatic bacteriuriat during pregnancy has been known for years to be associated with an increased risk of covert urinary tract infection [73]. Almost 30 years later, however, the magnitude of this risk and the effectiveness of antibiotics in reducing it are still a matter of controversy. Of those women with covert bacteriuria, $20 \%$ to $40 \%$ are destined to have an acute symptomatic infection. Treatment of covert bacteriuria might prevent $60-70 \%$ of all cases of acute urinary tract infections. Nevertheless, acute infections will develop in one-fifth of the 90-98\% with negative cultures at the first antenatal visit. In pregnancy, covert bacteriuria is an early feature. It seldom makes its appearance later than the $12^{\text {th }}$ week of gestation. 
2.3.2 Association between prematurity, small-for-dates and asymptomatic bacteriuria

While studying the prevalence of kernicterus in newborns of mothers treated with long-acting sulphonamides for asymptomatic bacteriuria, Kass unexpectedly noted a higher prematurity and low birth rate in untreated bacteriuric women than in the nonbacteriuric group. He proposed that asymptomatic bacteriuria was causally related to prematurity and stated that eradication of the infection would result in a significant. reduction of the incidence of premature births and low birth weight rate [74]. Over 29 years have elapsed since then and thousands of pages have been written on the association between covert urinary tract infection and pregnancy outcome. Some investigators support the relationship $[69,75]$, but many others were unable to find a significant correlation between bacteriuria and prematurity [76-80].

Two main types of studies have been performed to investigate the association between asymptomatic bacteriuria and prematurity and birth weight small-for-date: cohort studies and randomized clinical trials of treatment. Only a few of the cohort studies showed a statistically significant increase in the incidence of small-for-date infants born to women with asymptomatic bacteriuria $[69,74,81,82]$. After review of antibiotic treatment studies, it is not possible to definitely conclude that colonization of the urinary tract is directly responsible for prematurity. No experimental evidence has been established to support this view. It has been argued that the positive effect of antibiotic treatment may be mediated by the prevention of an excess of pyelonephritis in women with asymptomatic bacteriuria. An alternative explanation for the effectiveness of antibiotics in this setting may be attributed to eradication of infectious agents in sites other than the urinary tract. The most logical site to consider is the birth canal. In this case, asymptomatic bacteriuria may simply be a marker for abnormal colonization of the genito-urinary tract. This hypothesis is supported by recent studies in which antibiotic treatment of women with asymptomatic bacteriuria with group B streptococci resulted in a reduction of preterm delivery [83]. All women with group B streptococcus bacteriuria had colonization of the cervix and vagina with this organism. Antibiotic treatment may have altered the natural history of a group B streptococcal cervico-vaginal infection and prevented preterm delivery. However, group B streptococci are a highly infrequent cause of asymptomatic bacteriuria.

Given the maternal and possible fetal complications, Ampel and Zinner [84] advocated that all gravid women should be screened for bacteriuria at least once during their pregnancy, and treated if bacteriuria is detected and confirmed. 
In summary, however, from the evidence currently available, it must be concluded that although there may be a relation in some populations between bacteriuria and prematurity or small-for-dates, asymptomatic bacteriuria in itself does not appear to be a prominent factor in the genesis of these two adverse outcomes of pregnancy.

\subsection{Discussion}

A major problem in interpreting the results of the studies reviewed is the impossibility of directly comparing the detected associations between the presence of maternal genital micro-organisms and adverse pregnancy outcome. Several reasons account for this problem.

First, different associations are found in different study populations. The direct or indirect associations detected vary not only with the design of the investigation but, most of all, with the characteristics of the population studied. Many of the larger studies which detected a positive association have been performed in primarily indigent populations with a high prevalence of e.g. Chlamydia trachomatis. The impact of epidemiological risk factors on adverse pregnancy outcome will probably be more pronounced in such a population compared to a healthy, economically stable population.

Second, the outcome of pregnancy also is a result of the quality of antenatal care, and of the compliance of women with that care. In less privileged communities the compliance with antenatal care often is poor. This observation alone already results in an increased rate of e.g. prematurely born children. Since the prevalence of Chlamydia trachomatis in such communities is often high, the results of studies among these patients are likely to be biassed by the quality of antenatal care, and of the compliance of women with that care.

Third, many studies employed low birth weight as an outcome measure when gestational age could not be accurately calculated. In establishing an association between prematurity and a maternal genito-urinary infection, data on the prevalence of preterm birth should be separated from data on the prevalence of small-for-dates.

It is against this background that the data presented of previous studies and of the present investigation should be evaluated. 


\section{Literature}

1. Hablerstaedter L., von Prowazek S. 1907 . Uther Zelleinschlilisse parasitarer Nalur beim Trachom. Arb.Kaiserl.

Gesundheitsamte 26:44-47,

2. Haberstaedter L., von Prowazek S. 1907. Zur Aetiologie des Trachons. Dwsch. Med. Wochenschr. 33:1285-1287.

3. T'ang F-F, Chang H-1.. ct al. 1957. Trachoma virus in chick embryo. Naul.Med.J.China 43:81-86.

4. Gordon F., Quan A. 1965. Isolation of the trachoma agent in cell culture. Proc.Soc.Exp.Biol.Med. 118:354-359.

5. Grayston J.T., Kuo C.-C. et al. 1986. A new Chlamydia psitaci strain called TWAR from acute respiratory tract infections.

N.Engl.J.Med. 315:161-168.

6. Schachter J. 1978. Chlamydial infections. N.Engl.J.Med. 298:428,-435, 490-495, 540-549.

7. Storz J., Spears C. 1978. Chlamydiales: properties, cycle of development and effects on eucaryotic host cells.

Curt Top. Microbiol.Immunol. 76:167-21.4.

8. Byrne G.I. 1987. Chlamydiatrachomatis: Biology of the agent. In P.Reeve (eds.) Chllamydial infections. Springer-Verlag Berlin Heidelberg pp.78-95.

9. Taylor-Robinson D., Thomas B.J. 1980. The role of Chlamydia trachomatis in genital-tract and associated diseases.

J.Clin.Pathol. 33:205-233.

10. Schachter J.y Hanna L. et ail. 1975. Are chlamydial infections the most prevalent venereal disease?

J.Am.Med.Assoc. 231:1252-1255.

11. Osborne N.G., Grubin L. et al. 1982. Vaginitis in sexually active women: relationship to nine sexually transmitted organisms.

Am. J.Obstet.Gynecol. 142:962-967.

12. Berg A.O., Heidrich F.E. et al. 1984. Establishing the cause of genitourinary symptoms in women in a family practice: comparison of clinical examination and comprehensive microbiology.

J.Arr.Med.Assoc 251:620-625.

13. MeCormack W.M., Alpert S. et al. 1979. Fifteen-month follow-up sistudy of wamen infected with Chlamydia trachomatis.

N.Engl.J.Med. 300:123-125.

14. Schachter J., Stoner E. et all 1983. Screening for chlamydial infections in women attending family planning clinics.

West J.Med. 138:35-40.

15. Centers for Disease Control. 1985. Chlamydia trachomatis infections: policy guidelines for prevention and control.

MMWR. 34:(suppl. 3):53S-74S. 
16. Nagashima T. 1987. A high prevalence of chlanydial cervicitis in postmenopausal women.

Am.J.Obsitt Gynecol. 156:31 -32.

17. Schachter J. 1978. Chlanydial infections.

N.Engl.J.Med. 298:428-435, 490-495,540-549.

18. Harrison H.R., Boyce W.T. et al. 1983. The prevalence of genital Chlamydia trachomats and Mycoplasmal infection during pregnancy in an American Indian population.

Sex.Transm. Dis. 10:184. 186.

19. Toomy K.E. Rafferty M.P. et al. 1987. Unrecognized high prevalence of Chlamydiatrachomatis cervical infection in an isolated Alaskan Eskimo population.

J.Am.Med.Assoc. 258:53-56.

20. Khurana C.M.-, Deddish P.A. et al. 1985. Prevalence of Chlamydia trachomatis in the pregnatant cervix.

Obstet Gynecol. $66: 241-243$.

21. Persson K., Ronnerstam R. ct al. 1981. Matemal and infantile infection with chlamydia in a Swedish population.

Acta Paediatr.Scand. 70:101-105.

22. Moncada J.V., Schachter J.et al. 1987. Chlamydiatrachomatis infection among patients undergoing chorionic villus sampling.

Am.J.Obstet.Gynecoll. 156:915-916.

23. Harrison H.R., Alexander E.R. et ah. 1982. Epidemiologic correlations of genital infections and outcomes in pregnancy. In Mårdh P. , Holmes K.K., Oriel J.D., Piot P., Schachter I. (eds.) Chlamydial infections. Elsevier Biomedical Amsterdam pp. 159-162.

24. Edwards L.E., Barrada M.I. et al. 1978. Gonorrhea in pregnancy. Am.J.Obstel.Gynecol. 132:637.

25. Regan J.A., Chao S., James L.S. 1981. Premature rupture of membranes, pretem delivery, and group B streptococcal colonization of mothers.

Am.J.Obstet.Gynecol. 141:184.

26. Martin D.H., Koutsky L, et al. 1982. Prematurity and perinatal morialiuy in pregnancies complicated by maternal Chlamydia trachomatis infections.

J.Am.Med.Assoc. 247:1585-1588.

27. Harrison H.R., Alexander E.R. et al, 1983. Cervical Chamydia trachomatis and mycoplasmal infections in pregnancy: Epidemiology and outcomes.

J.Am.Med.Assoc. 250:1721-1727.

28. Ross S.M., Windsor I.M. et al. 1984. Microbiological studies during the perinatal period: An attempt to correlate selected bacterial and viral infections with intrauterine deaths and pueterm labour.

S.Afr.Med I. 86:596.

29. Lamont R.F., Taylor-Robinson D.et al. 1986. Spontaneous early preterm labour associated with abnormal genital bacterial colonization.

Br.J.Obstet Gynaecol. 93:804. 
30. Gravett M.G., Nelson H.P. et al. 1986. Independent associations of bacterat vaginosis and Chlamydiatrachomatis infection with adverse pregnancy outcome. J.Am Med.Assoc. 256:1899-1903.

31. Sweet R.L., Landers D.V. et al. 1987. Chlamydta trachomatis infection and pregnancy outcome.

Am.J.Obstet.Gyneciol. 156:824-833.

32. Martius $\mathbb{I}$, Krohn M.A. el al. 1988. Relationships of vaginal lactobacillus species, cervical Chlamydia trachomatis, and bacterial vaginosis to preterno bith. Obstet.Gynecol. 71:89-94.

33. Alger L.S., Lovchik J.C. et al. 1988. The association of Chlawydia trachomatis, Neisseria gonorrhoea and group $B$ streptococci with preterm rupture of the membranes and pregnancy outcome.

Am.J.Obsiell.Gynecol. 159:397-404.

34. BJeker O.P., van der Schoot J.T et all. 1987. Cervicitis en salpingitis.

Tijdschrift woor Sexueel Overdraagbare Aandoeningen. 4:4:9.

35. Smith J. W, Rogers R.E. et al. 1987. Diagnosis of chlamydial infection in women attending antenatal and gynecologic clinics.

J.Clin.Microbiol. 25:868-872.

36. Berman S.M., Harrison H.R. et al. 1987. Low birth weight, prematurity, and postpartum endometritis. Association with prenatal cervical Mycoplasma hominis and Chlamydia trachomatis infections.

J.Am.Med.Assoc. 257:1 189-1194.

37. Schachter J., Grossman M. et al. 1986. Prospective study of perinatal transmission of Chlamydia trachomatis.

J.Am.Med.Assoc. 255:3374-3377.

38. Schachter J., Hill E.C. et al. 1975. Chlamydial infection in women with cervical dysplasia.

Am.J.Obstet.Gynecol. 123:753-757.

39. Mardh P-A., Helin I.et al. 1980. Colonization of pregnant and puerperal women and neonates with Chlamydia trachomatis.

Br.J.Vener.Dis. 56:96-100.

40. Ross J.M., Furr P.M. et al. 1981. "The effect of genital mycoplasmas on human fetal growth.

Br.J.Obstet,Gynaecol. 88:749-755.

41. Grossman M., Schachter J. et al. 1982. Prospective studies in Chlamydia in newborns. In Mardh P.A., Holmes K.K., Oriel J.D., Piot P., Schachter I.(cds.) Chlamydial infections. Elsevier Biomedical Amsterdam pp.213-216.

42. Van der Meijden W.I., Schmitz P.I.M. ct al. 1988. Some aspects of the diatgnosis of specific vaginal infections in the Rotterdam STD clinic population.

Europ.J.Obstet.Gynecol.Reprod.Biol. 28:53-64.

43. Ruijs G.J., Kauer F.M. et al. 1988. Direct immunofluorescence for Chlamydia trachomatis on urogenital smears for epidemiological purposes.

Europ.J.Obstet.Gynecol.Reprod.Biol. 27:289-297. 
44. Dienes L., Edsall G. 1937. Observations on the L-organism of Klieneberger. Pre.Soc.Exp.Biol Med. 36:740-744.

45. Tourtellote $M$. Lein D. 1976 . Infertility of catle caused by mycoplasmas. Health Lab.Sci. 13:152-157.

46. Stallheim D., Proctor S. 1976. Experimentally induced bovine abortion with Mycoplasma agalachae subspecies bovis.

Am. J. Vet.Res. 37:879-884.

47. Styller M.; Shapiro S.S. 1985. Mollicutes (mycoplasma) in infertility. Feril.Steril. 44:1-12.

48. Razin S. 1985. Molecular biology and genetics of Mycoplasmas (Mollicues). Microbioll Rev. 49:419-455.

49. MeCormack $W_{c}$, Rankin J. 1971. Localization of genital mycoplasmas in women.

Am.J.Obstel,Gynecol. 112:920-923.

50. IWassaka T., Wada T. et al. 1986. Genital mycoplasma colonization in neonatal girls.

Acta Obstel. Gynecol.Scand. 65:269-272.

51. MeCormack W.M., Almeïda P.C. ct al. 1972. Sexual activity and vaginal colonization with genital mycoplasmas.

I.Am.Med.Assoc. 221:1375-1377.

52. Mârdh P., Weström L. 1970. T-mycoplasma in the genito-urinary tract of the female.

Acta Pathol.Scand. 78:367-374.

53. Iwasaka T., Wada T. et al. 1986. Hormonal status and mycoplasma colonization in the female genital tract.

Obstet. Gynecol, 68:263-266.

54. Hammerschlag M, Alpert S. et al. 1978. Microbiology of the vagina in children: normal and potentially pathogenic organisms.

Pediatrics 62:57-62.

55. Furr P., Taylor-Robinson D. 1984. Enhancement of experimental Mycoplasma pulmonis infection of the mouse genital tract by progesterone treatment. J.Hyg. $92: 139-\llbracket 42$.

56. Ross J.M., Furr P.M. et al. 1981. The effect of genital mycoplasmas on human fetal growth.

Br.J.Obstet.Gynecol. 88:749-755.

57. Minkoff H., Grunebaum A.N. et al. 1984. Risk factors for prematurity and premature rupture of membranes: a prospective study of the vaginal flora in pregnancy.

Am.J.Obstet.Gynecol. 150:965-970.

58. Harrison H.R., Alexander E.R. el al. 1983. Cervical Chlamydia trachomatis and mycoplasmal infections in pregnancy: Epidemiology and outcomes.

J.Am.Med.Assoc. 250:1721-1727. 
59. Martius J., Kroinn M.A. et al. 1988. Relationships of vaginal lactobacillus species, cervical Chamydia trachomatis, and bacterial vaginosis to pretem birth. Obstet.Gynecol. 71:89-94..

60. Elder H.A., Santamarina B.A. et al. 1971. The natural history of asymptomatic bacteriuria during pregnancy: the effect of tetracycline on the clinical course and the outcome of pregnancy.

Am.J.Obstet.Gynecol. 111:441-462.

61. Williams C.M., Okada D.M. et al. 1987. Chincal ind microbiologic risk evaluation for post-cesarean section endometritis by multiwariate discriminan analysis: Role of intraoperative mycoplasma, aerobes, and anaerobes. Am.J.Obstet.Gynecol. 156:967-974.

62. Klein J.O., Buckland D. et al. 1969. Colonization of newborn infants by mycoplasmas.

N.Engl.J.Med 280:1025-1030.

63. Braun P., Lee Y-H. el al. 1971. Birth weight and genital mycoplasmas in pregnancy.

N.Engl.J.Med. 284:167-171.

64. Upadhyaya M., Hibbard B.M.ct al. 1983. The role of mycoplasmas in reproduction.

Fertil.Steril. 39:814-818.

65. Harrison H.R. 1986. Cervical colonization with Ureaplasma ureatyticum and pregnancy outcome: prospective studies.

Pediatr. Infect.Dis. 5 suppl:266-269.

66. Kass E.H., McCormack W.M. et al. 1981. Genital mycoplasmas as a cause of excess premature delivery.

Trans.Assoc.Am.Physicians 94:260-264.

67. Foy H.M., Kenny G.E. et al. 1970. Isolation of Mycoplasma hominis, T-strains, and cytomegalovirus from the cervix of pregnant women.

Am.J.Obstet.Gynecol. 106:635-639.

68. Harrison R.F. Hurley R. et al. 1979. Genital mycoplasmas and birth weight in offspring of primigravid women.

Am.J.Obstet.Gynecol. 133:201-203.

69. Kincaid-Smith P., Bullen M. 1965. Bacteriuria in pregnancy.

Lancet 1:395-399.

70. Whalley P., Martin F. el al. 1965. Significance of asymptomatic bacteriuria during pregnancy.

J.Am.Mcd.Assoc. 193:879-886.

71. Monzon O.T., Armstrong D. et al. 1963. Bacteriuria during pregnancy. Ami.J. Obstet.Gynecol, 85:511-518.

72. Kass E.H. 1982. How important is bacteriuria?

Rev. Infect.Dis. 4:434-436.

73. Kass E.H. 1960. The role of asymptomatic bacteriuria in the pathogenesis of pyelonephritis. In Quin E.L., Kass E.H. (eds.) Biology of pyelonephritis. Litule, Brown \& Company. Boston pp.399 412 . 
74. Kass E.H. 1962. Pyelonephritis and bacteriuria: a major problem in preventive medicine.

Ann.Intem. Med. 56:46-51

75. Brumfitt W., Grüneberg R.N., et al. 1967. Bacteriuria in pregnancy with reference to prematurity and long tem effects on the mother. In Symposium on Pyelonephritis, Edinburgh 1966. Edinburgh, Livingstone p.20.

76. Bryant R., Windom R. et al 1964. Asymptomatic bacteriuria in pregnancy and its association with premanurity.

J.Lab.Clin.Med. 63:224-231.

77. Sleigh J.D., Robertson J.G., lsdale M.H. 1964. Asymptomatic bacteriuria in pregnaricy.

J.Obstet.Gynaecol.Br.Commonw. 71:74-81.

78. Norden C.W., Kilpatrick W.H. 1965. Bacteriuria in pregnancy. In Kass E.H. (ed.) Progress in Pyelonephritis. Philadelphia, F.A. Davis. p.64.

79. Liule P.J. 1966. The incidence of urinary infection in 5000 pregnant women. Lancet 2:925-928.

80. Dixon H.G., Brant H.A. 1967. The significance of bacteriuria in pregnancy. Lancet 1:19-20.

81. Wren B.G. 1969. Subclinical renal infection and prematurity. Aust.J.Med. 2:596-599,

82. Brumfitt W. 1975. The effects of bacteriuria in pregnancy on maternat and fetal health.

Kidney Int. (Suppl) 8:113-118.

83. Thomson A.C., Morup L. et al. 1987. Antibiotic elimination of group B streptococci in urine in preverntion of preterm labour.

Lancet 1:591-594. 


\section{Population and methods}

\subsection{Study design and study population}

The investigation was designed as a hospital-based prospective cohort study in pregnant women on the relationship between the endocervical prevalence of Chlamydia trachomatis, Mycoplasma hominis and Ureaplasma urealyticum and pregnancy outcome. In addition, the presence of asymptomatic bacteriuria was related to pregnancy outcome as well. The presence of either one of the three micro-organisms and of asymptomatic bacteriuria was recorded at the first antenatal visit. The course and outcome of pregnancy were recorded.

The study was conducted at the obstetric departments of two hospitals located in a rather well defined region in the most southern part of the Netherlands. Together these two hospitals serve over $65 \%$ of the pregnant women in their catchment area. Women are referred to these hospitals by their family doctors because of an obstetrical, medical or social indication. Midwives working outside the hospitals are responsible for the antenatal care and delivery at home of the remaining 35 percent. The population is predominantly white and of a middle class socio-economic level.

The hospitals participated in the study for various lengths of time. In September 1985 the study started at the antenatal clinic of the University Hospital of Maastricht. In June 1986 the study was extended to the antenatal clinic of the St. Elisabeth Clinic, a training institute for midwives situated in Heerlen. At the end of December 1988, screening of pregnant women ended in both participating hospitals. In Table 3.1 the number of women contributed to the investigation by each clinic are presented.

Table 3.1

Number and percentages of women contributed by the participating clinics.

\begin{tabular}{llll}
\hline clinic & & $\mathrm{n}$ & $\%$ \\
\hline University Hospital & Maastrich & 638 & 42 \\
St. Elisabeth Clinic & Hecrlen & 864 & 58 \\
\hline
\end{tabular}

$N=1502$ 
The study population comprised approximately $60 \%$ of all women seeking initial antenatal care at the two clinics. Among the $40 \%$ of the women not enrolled, about $8 \%$ refused to participate in the studly. The remaining $32 \%$ either presented too late in pregnancy or were not included for various reasons, the main one being personnel shortage, not maternal characteristics. Using information derived from the "Landelijke Verloskundige Registratie" (National Obstetric Data system) of the two hospitals, maternal age and parity of the participating women were compared with corresponding data of all mothers who delivered in these hospitals in 1987. No significant differences were found.

The study design was consented to by the ethical board of the University Hospital of Maastricht.

\subsection{Eligibility criteria}

Essentially, all pregnant women referred to the antenatal clinic of any of the two hospitals were eligible to participate in the study at their first antenatal visit. The only criterion not to include a woman was a gestational age of more than 18 weeks. Excluded from the analysis were the pregnancy outcome data of women with recognizable causes of prematurity, such as multiple gestations, elective induction of labour and primary Caesarean section prior to 36 completed weeks of gestation. Nevertheless, the results of the microbiological tests of these women were used to estimate the prevalence of the genital microorganisms studied and that of asymptomatic bacteriuria.

\subsection{Aims and procedures}

At their initial antenatal care visit, eligible pregnant women were handed out a letter explaining the aims and the procedures of the study. If necessary, additional information was given by the nursing staff of the outpatient departments at the two hospitals. After written informed consent, the women were enrolled.

The participating women were each assigned a unique investigation number. All samples and data collected from a particular woman were identified and recorded by that number. Number and name were known onlly to the principal investigator to ensure strict privacy.

Data were collected on two occasions during pregnancy. Epidemiological data, cervical cultures and urine specimens were collected at the initial antenatal visit. At the beginning of the third trimester of preg- 
nancy, blood samples were obtained for determination of maternal haemoglobin level. Also, testing of urine specimens for asymptomatic bacteriuria was repeated.

On both occasions, the women participating were asked to complete a questionnaire for additional information not readily available in the maternal records. The first questionnaire included maternal schooling, alcohol consumption and smoking habits, previous (recurrent) infections of the urinary tract and previous infections of the genital tract [addendum 1]. In the second questionnaire the use of antibiotics, alcohol consumption and smoking habits during pregnancy were recorded, as well as the pattern of micturition [addendum 2]. After delivery, all medical records were reviewed with special regard to the occurrence of preterm rupture of membranes, preterm labour and birth weight [addendum 3]. The items recorded are presented in detail in paragraph 3.4 "Registered data and definitions". The questionnaires, together with subsequent medical record review, provided the epidemiological and pregnancy outcome data.

All participating women were regularly checked -on a routine basis- by their attending gynaecologist, at least ten times during pregnancy.

Neither the gynaecologist nor the woman were informed about the microbiological results. However, the pediatrician was informed in case a positive maternal specimen for Chlamydia trachomatis was detected.

\subsection{Registered data and definitions}

The data registered comprised demographic, behavioural, medical and laboratory variables. The epidemiological variables recorded consisted of:

Demographic variables

Maternal age at the time of the first antenatal visit.

Maternal height, measured in centimeters, without footwear.

Maternal educational attainment divided in: less than high school, high school, vocational training, or university and unknown.

\section{Behavioural variables}

Smoking habits: the number of cigarettes smoked per day at the first antenatal visit and at the beginning of the third trimester of pregnancy.

Alcohol consumption: the number of glasses of alcohol consumed per week at the first antenatal visit and at the beginning of the third trimester of pregnancy. 


\section{Medical variables}

Pregnancy was defined as the total number of proven pregnancies, including the pregnancy at issue.

Parity was defined as the total number of deliveries after a gestational age of 15 completed weeks. Multiple births were recorded as one pregnancy. The number of abortions was considered as the total of miscarriages and induced abortions before the $16^{\text {th }}$ week of gestation.

Previous preterm delivery: the number of deliveries at a gestational age between 28 and 37 completed weeks.

Previous immature delivery: the number of deliveries at a gestational age of less than 28 completed weeks.

Previous small-for-date neonates: the number of children with a birth weight of less than the $10^{\text {th }}$ percentile.

Recurrent urinary tract infections, history obtained by questionnaire [addendum 1].

Previous infections of the lower genital tract, history obtained by questionnaire [addendum 1].

Intercurrent diseases during pregnancy, obtained by review of maternal medical record.

\section{The obstetrical variables comprised}

Gestational age at enrollment (in completed weeks and days). The amenorrhoea was determined by a combination of the last menstrual period and first trimester ulltrasonography.

Spontaneous abortion: the spontaneous ending of pregnancy before 16 completed weeks.

Preterm rupture of membranes: rupture of the membranes both prior to 36 completed weeks of gestation and prior to labour. Rupture of membranes was confirmed by the presence of a fern arborization pattern on microscopic examination of vaginal fluid. To prevent duplication of data, only preterm rupture of membranes that occurred in the absence of labour was recorded as such. Gestational age in case of preterm rupture of membranes was recorded in completed weeks and days. Use of intravenous tocolytic therapy after preterm rupture of membranes was recorded as well.

Preterm labour: the presence of regular painful contractions occurring at least every five minutes (and evidence of progressive cervical dilatation or effacement) in the second or third trimester of pregnancy but before 37 completed weeks of gestation. Gestational age in case of preterm labour was recorded in completed weeks and days. Use of intravenous tocolytic therapy after preterm labour was also recorded. 
Gestational age at delivery was recorded in completed weeks and days. If the gestational age was not completely certain, a best estimate was given in intervals of one week.

Birth weight: the weight (in grams) of the new born, obtained within the first hour of life.

Birth weight small-for-date; since birth weight is correlated with gestational age, parity and sex of the new born, small-for-date was defined as a percentile of less than $P_{10}$, according to the Amsterdam growth table [1]. In general, the reasons for an infant being small fordate are chromosomal disorders, being genetically small, and intrauterine growth retardation. In this study, data of infants born with known chromosomal disorders were excluded from analysis.

Placental weight was recorded in grams.

Fetal survival at birth. Ante partum fetal death and intra partum fetal death were recorded as separate entities.

Umbilical arterial pH was determined immediately after birth.

Admission to neonatal unit: any stay of the newborn at the neonatal unit with the reason(s) for admission.

Pregnancy induced hypertension: diastolic pressure $\geq 90 \mathrm{~mm} \mathrm{Hg}$ in second or third trimester of gestation or $20 \mathrm{~mm} \mathrm{Hg}$ rise in diastolic pressure for more than 2 weeks during pregnancy. Only women who met these criteria during clinical observation were recorded as such.

Diabetes mellitus or any disorder of the maternal serum glucose level requiring insulin therapy, was recorded as well as the gestational age at which the therapy started.

Drug use during pregnancy: all prescribed drugs were recorded, in particular the use of any antibiotics, irrespective of the cause.

Laboratory data comprised determination of the presence or absence of

Chlamydia trachomatis by a direct immunofluorescence test. Inadequate specimens or specimens not received were recorded as unknown. Mycoplasma hominis by culture. Ureaplasma urealyticum by culture. Asymptomatic bacteriuria by culture.

Specimens not received were recorded as unknown.

Haemoglobin level in $\mathrm{mMol} / \mathrm{l}$, recorded at the beginning of the third trimester of pregnancy. 


\subsection{Specimen collection and laboratory procedures}

\subsubsection{Chlamydia trachomatis}

Detection of Chlamydia trachomatis was performed using a direct immunofluorescence test (MicroTrak, Syva Company, Palo Alto, California, USA). The specimens were obtained by the various gynaecologists who staffed the clinics. During vaginal examination and exposing the cervix, (after removal of excess cervical mucus), specimens for Chlamydia trachomatis were collected by using a cotton swab on a plastic shaft (collection kit MicroTrak, Syva). The tip of the swab was introduced entirely into the endocervical canal and rotated firmly against the wall of the endocervix for at least 5 seconds in order to obtain a sufficient amount of exfoliated endocervical cells. Immediately after collection, the swab was rolled parallel to the surface of the slide over a well with a diameter of $8 \mathrm{~mm}$. All the portions of the swab surface were used to apply material to the well. The slides were fixed by squeezing all the acetone from an ampoule (provided by the manufacturer) on to the surface of the slide and allowing it to evaporate completely. Upon receipt in the laboratory, the slides were placed in the deep freeze $\left(-20^{\circ} \mathrm{C}\right)$ until staining (within 3 days), according to the manufacturer"s instructions.

In this assay, fluorescein labelled monoclonal antibodies (reacting with all 15 known human serovars of Chlamydia trachomatis) are used to stain both elementary as well as reticulate bodies [2]. In short, twentyfive microliters of the fluorescein-conjugated monoclonal antibody against Chlamydia trachomatis outer membrane and Evans blue counterstain were added to the slide well. After incubation at room temperature for 15 to 30 minutes, the slides were rinsed in distilled water for 5 minutes and allowed to dry in air. Mounting fluid and a coverslip were added, and the slides were examined within 4 hours by using an epifluorescence microscope (Leitz) with a mercury light source. Smears were scanned at $400 \mathrm{x}$ magnification with an oil immersion objective. The entire well of each slide was examined. The presence of collumnar and cuboidal cells mixed with polymorphonuclear leukocytes indicated that the specimen was adequate. Acellular smears and smears containing only squamous cells were considered inadequate and scored as unknown. A specimen was considered positive if 10 or more distinct apple-green fluorescein-stained elementary bodies were visible.

The direct immunofluorescence test used in this study is the most extensively evaluated non-culture technique for detection of Chlamydia trachomatis. Isolation of the organism in tissue culture has long been held to be the gold standard for the diagnosis of chlamydial infections, 
but the high cost of personnel, materials, and equipment puts this diagnostic procedure beyond the reach of many laboratories. Compared to the culture technique, the direct immunofluorescence test has a reported sensitivity of $69-99 \%$ and a specificity of $94-99 \%$ in women [3]. As a result of the inherent specificity of the monoclonal antibodies, the specificity of this direct immunofluorescence test is high. The sensitivity however is influenced by the experience of the interpreter [4]. In this study, interpretation of the specimens for Chlamydia trachomatis was performed by a skilled senior technologist. A major advantage of the direct immunofluorescence test is that the quality of the specimen can be observed directly.

\subsubsection{Mycoplasma hominis and Ureaplasma urealyticum}

Specimens for Mycoplasma hominis and Ureaplasma urealyticum cultures were obtained from the endocervical mucus and the posterior fornix of the vagina by two separate cotton-tipped wooden swabs. The collection of the specimens was performed during the same gynaecological examination as for the collection of the specimen for Chlamydia trachomatis. Each swab was placed in a separate vial containing $1.5 \mathrm{ml}$ of mycoplasma transport medium (horse serum $20 \% \mathrm{vol} / \mathrm{vol}$, yeast extract $10 \% \mathrm{vol} / \mathrm{vol}$, urea $0.1 \%$ in trypticase soya broth $\mathrm{BBBL}$ Microbiological Systems, Cockeysville, USA) which included $2 \mathrm{mg} / \mathrm{l}$ cefotaxime). The specimens were kept at $4^{\circ} \mathrm{C}$ for a maximum of 2 hours before being stored at $-20^{\circ} \mathrm{C}$ at the laboratory. Processing for culture took place within 3 days.

The methods used for the isolation of Mycoplasma hominis and Ureaplasma urealyticum have been performed as described in detail by McCormack et al. [5]. The specimens were transferred into trypticase soya broth containing either $0.1 \%$ urea for the detection of Ureaplasma urealyticum or $0.1 \%$ arginine for the detection of Mycoplasma hominis. Phenol red $(0.2 \%)$ was used as indicator. Mycoplasma hominis metabolizes arginine to ammonia, thus raising the $\mathrm{pH}$ of the medium. Ureaplasma urealyticum possesses a urease that breaks down urea to ammonia, producing a similar $\mathrm{pH}$ change. After one to two days incubation at $37^{\circ} \mathrm{C}$ in $2.5 \% \mathrm{CO}_{2}$ in air, the culture tubes showing colour changes were subcultured onto mycoplasma agar medium (trypticase soya agar horse serum $20 \% \mathrm{vol} / \mathrm{vol}$, yeast extract $10 \% \mathrm{vol} / \mathrm{vol}$, urea $0.1 \%$, L-cysteine $0.1 \%$ ). If no colour changes were observed the tubes were blindly subcultured onto agar medium. For the isolation of Mycoplasma homimis the plates were incubated in an atmosphere of $\mathrm{H}_{2}$ and $5 \% \mathrm{CO}_{2}$. For Ureaplasma urealyticum the plates were anaerobically incubated for three to five days. Identification of Mycoplasma hominis was based on 
the typical fried egg appearance of the colonies. Dark brown colonies, due to a brown deposit on manganese containing medium, were identified as Ureaplasma urealyticum. This liquid-to-agar technique is the most sensitive qualitative method for the isolation of both Mycoplasma hominis and Ureaplasma urealyticum [6]. The sensitivity for Mycoplasma hominis is over $90 \%$ and that for Ureaplasma urealyticum is over $80 \%[7]$.

\subsubsection{Asymptomatic bacteriuria}

Clean-voided midstream portions of urine were collected by the participants in sterile containers and stored at $4^{\circ} \mathrm{C}$. Laboratory testing included quantitative and qualitative bacteriological assessment of the urine specimen. After thoroughly mixing of the urine specimen, $20 \mu \mathrm{l}$ was streaked onto a $7 \%$ sheep blood agar plate (Oxoid, CM55, Basingstoke, UK) and a MacConkey agar plate (Oxoid, CM7, Basingstoke, UK). Both plates were incubated at $37^{\circ} \mathrm{C}$ for $18-24$ hours. A number of $10^{5}$ or more colony forming units per $\mathrm{ml}$ of the same species was considered positive. The micro-organisms were identified according to the methods of Edwards and Ewing [8].

\subsection{Data collection and handling}

Data concerning each individual pregnant woman were recorded on five consecutive data forms. A complete set of forms consisted of two questionnaires (to be filled out by the woman) [addenda 1,2]; two forms containing the laboratory results and finally a form containing maternal. reproductive and pregnancy outcome data [addendum 3]. Data of each form were entered on screen to separate data files on the DEC VAX8650 of the University of Limburg. In order to minimize data entry errors, the software of the entry screens included build-in controls for out of range entries and inconsistency of data. After verification, the data files were emulated into one single record per individual. Eventually, these records were used for the statistical analysis.

\subsection{Statistical analyses}

The relation of pregnancy outcome to the prevalence of either one of the three micro-organisms and asymptomatic bacteriuria was examined in several consecutive sets of analyses. Gestational age at delivery and birth weight were defined as dependent variables, whereas the micro- 
organisms of interest and asymptomatic bacteriuria were defined as primary independent variables. Demographic, behavioural and medical factors, (listed in paragraph 3.4), were defined as secondary independent variables. Table 3.2 schematically depicts the elaboration terminology. The examined independent secondary variables, related to the pregnant women were maternal age, maternal educational attainment, smoking habits, alcohol consumption, pregnancy, parity, medical history regarding genito-urinary tract infections and prevalence of preterm born and/or small-for-date infants in previous pregnancies. Independent secondary variables, related to the pregnancy at issue, were preterm labour, preterm rupture of membranes, maternal haenoglobin at the beginning of the third trimester of gestation, pregnancy induced hypertension, gestational age at delivery, type of delivery, birth weight and sex of the infant, placental weight, and $\mathrm{pH}$ of umbilical arterial blood.

The analyses treated the pregnancy outcome dependent variables (i.e. gestational age at delivery and birth weight), as dichotomous for descriptive purposes. Both variables were dichotomised in order to enable cross-tabulation analysis of the obtained data. Gestational age and birth weight were dichotomised according to the median in order to establish an equal distribution of data. By using equal classes for dependent variables, detection of a possible relationship between dependent and independent variables will be optimal [9]. Association of birth weight or gestational age at delivery with any of the primary or secondary independent variables, will be reflected in unequall counts for the dependent categories within categories of the independent variable.

Table 3.2

Elaboration terminology

Dependent variables

Independent wariables primary

secondary gestationall age at delivery birth weight

Chlamydia trachomatis

Mycoplasma hominis

Ureaplasma urealyticum

asymptomatic bacteriuria

demographic factors

behavioural factors

medical factors 
The conceptual model of the analysis is schematically presented in Figure 3.1.
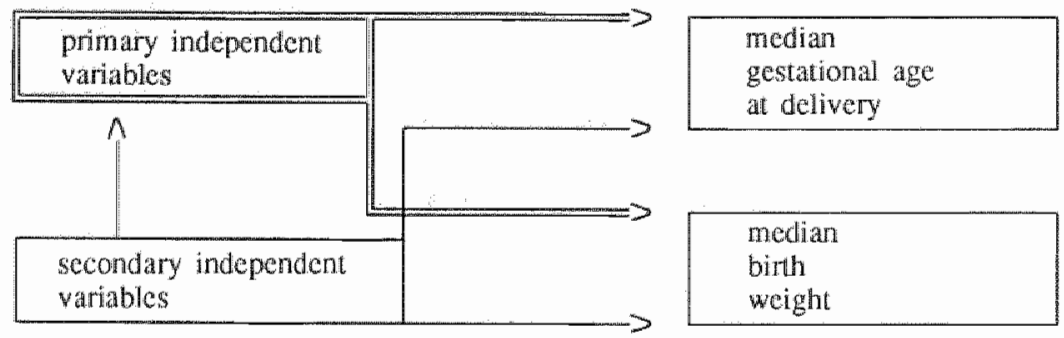

Frigure 3.1 Concepiwal model of analysis.

Initially, all independent variables were included in the analyses. Repeated bivariate cross-tabulations were performed to establish whether presence of any of the independent variables measured was associated with each of the dichotomised pregnancy outcome dependent variables. A $p$ value of $<0.05$ for the chi-square statistic wals considered significant. This procedure selected the relevant independent variables in the studied group of pregnant women.

Also bivariate cross-tabulations were performed to investigate the relationship between the primary and secondary independent variables. To this aim, the secondary independent variables were dichotomised according to plausible categories, or to the median. This procedure selected secondary independent variables of which categories were associated with the prevalence of any of the micro-organisms. Using trivariate cross-tabulations, the indirect relationship between any of the micro-organisms versus birth weight and gestational age was investigated, controlling for the secondary independent variables.

Using multiple linear regression analysis, birth weight and gestational age at delivery were regressed by the primary and secondary independent variables. The independent variables associated with birth weight and gestational age in bivariate and trivariate analyses were considered in the regression models. In addition, independent variables which, on theoretical grounds, were expected to be related to birth weight and gestational age were considered in the regression models. 
Assuming a saturated model in which all main effects and n-order effects were included, a hierarchical procedure was used to find the optimal fitting (unsaturated) model.

Using logistic regression analysis, secondary independent variables were related to the presence of the micro-organisms studied. Also logistic regression analysis were used considering relevant secondary independent variables with birth percentile as dependent variable. Birth percentiles were dichotomised according to $\mathrm{P}_{50}$.

\section{Literature}

1. Kloosterman G.J. 1970. On intrauterine growth. Int.J.Gynecol.Obstet. 8:895-900.

2. Quinn T.C., Warfield P. et al. 1985. Screening for Chanydia trachomatis infection in an innercity population: a comparison of diagnostic methods. J.Infect.Dis. 152:419-423.

3. Stamm W.E. 1988. Diagnosis of Chlamydia trachomatis genitourinary infections. Ann.Intern.Med. 108:710-717.

4. Liwengood C.H., Schmitt J.W. et al. 1988. Direcl fluorescent antibody testing for endocervical Chlamydiat trachomatis: factors affecting accuracy. Obstet.Gynccol. 72:803-809.

5. McCormack W.M., Braun P. et al. 1973. The genital mycoplasmas. N.Engl.J.Med. 288:78-89.

6. Taylor-Robinson D., Furr P.M. 1981. Recovery and identification of human genital tract mycoplasmas. Isr.J.Med.Sci. 17:648-653.

7. Braun P., Klein J.O. et al. 1970. Methodologic investigations and prevalence of genital mycoplasmas in pregnancy. J.Infect.Dis. 121:391-400.

8. Edwards P.R., Ewing W.H. 1972. Identification of Enterobacteriaceac, 3rd ed. Burgess Publishing, Minncapolis.

9. Swanborn P.G. 1984. Methoden van sociaal welenschappelijk onderzock Uitgeverij Boom, Meppel. 


\section{Results}

In this chapter the results and the analysis of the data are presented in three main sections. In the first section the composition of the study group is delineated and data are presented on demographic, behavioural, and medical characteristics as well as on pregnancy outcome of this sample of the group of pregnant women studied.

The prevalences of Chlamydia trachomatis, Mycoplasma hominis, Ureaplasma urealyticum and asymptomatic bacteriuria detected are presented in the second section. Subsequently, the question whether the presence of the micro-organisms or the presence of asymptomatic bacteriuria affects gestational age at delivery and birth weight is addressed in a first statistical exploration. Similarly, relationships are analyzed between the demographic, behavioural, and medical variables and birth weight and gestational age respectively.

In the final section, significant associations were sought between the presence of Mycoplasma hominis, Ureaplasma urealyicum, asymptomatic bacteriuria and/or decreased birth weight and preterm birth. In addition, the relation of the maternal demographic, behavioural, and medical variables with these two outcomes of pregnancy was investigated. Due to the small number of women in the study group infected by Chlamydia trachomatis, a reliable statistical analysis of the datat related to Chlamydia trachomatis was not possible. The data of the women with a positive immunofluorescence test for Chlamydia trachomatis are presented separately in a descriptive manner.

\subsection{Study group}

From September 1985 to December 1988, a total of 1502 pregnant women agreed to participate in the study. The antenatal clinic of the University Hospital in Maastricht accounted for $638(42 \%)$ of these women. Of the remaining 864 women, $733(49 \%)$ were enrolled by the gynaecologists and $131(9 \%)$ by the midwives of the Sint Elisabeth Clinic in Heerlen.

On January $15^{\text {th }} 1989$ the recording of data ended. Women still pregnant were not included in the analysis of birth weight and gestational age since their pregnancy outcome data were not available at that time. Furthermore, data from women who on second thoughts, decided not to participate any further in the study, and data from a few women who 
moved out of the area before the ending of their pregnancy, were excluded. Epidemiological and medical data of these women did not differ significantly from the remaining group of participants. Since in addition twenty-six of the medical records were unavailable for followup, the resulting cohort of participants available for analysis contained 1298 gravid women. The study group used for the descriptive and statistical analyses comprised therefore 1298 from the 1502 initial enrolled women. In the calculations however, the actual size of the study group varies because of missing values.

\subsubsection{Characteristics at enrollment}

Women were enrolled in the investigation in the first trimester of pregnancy. As shown in Figure 4.1, the median of the gestational age of the study group was 10.0 weeks at the booking visit. Almost half of the women was enrolled after the second missed menstrual period, i.e. in between the $8^{\text {th }}$ and $13^{\text {th }}$ week of pregnancy. Women were eligible to enter the investigation at an expected gestational age of less than 18 weeks. However, of 27 women the actual duration of pregnancy was readjusted afterwards by ultrasonography, resulting in a range from 5.0 to 21.0 weeks of amenorrhoea at intake. The mean gestational age at the time of enrollment was $10.7 \pm 3.1$ weeks. The median and mean were calculated out of 1270 valid cases. In 28 cases the exact gestational age was not known at enrollment.

The demographic and behavioural characteristics at enrollment of the total study group are listed in Table 4.1. Characteristics were grouped in several consecutive categories. Unknown and/or missing values are presented as a separate category.

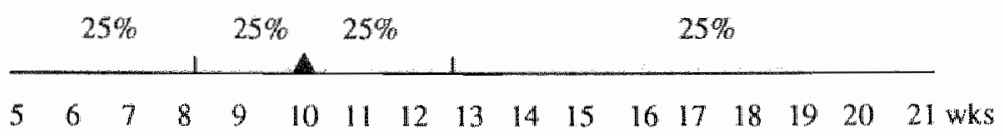

Figure 4.1

Median ( $\mathbf{A}$ ) and range of gestational age (weeks) at enrollment.

$\mathbb{N}=1270$ 
Table 4.1

Characteristics of the study group at enrollment.

\begin{tabular}{|c|c|c|}
\hline Characteristic & $\mathrm{n}$ & $\%$ \\
\hline \multicolumn{3}{|l|}{ Age (year) } \\
\hline$<20$ & 28 & 2.2 \\
\hline $20-24$ & 200 & 15.4 \\
\hline $25-29$ & 537 & 41.4 \\
\hline $30-34$ & 377 & 29.0 \\
\hline $35-39$ & 100 & 7.7 \\
\hline$\geq 40$ & 2 & 0.2 \\
\hline unknown & 54 & 4.2 \\
\hline \multicolumn{3}{|c|}{ Educational attainment } \\
\hline$<$ hìgh school & 400 & 30.8 \\
\hline high school & 472 & 36.4 \\
\hline$>$ high school & 357 & 27.5 \\
\hline unknown & 69 & 5.3 \\
\hline \multicolumn{3}{|c|}{ Cigarette smoking (cigarettes/day) } \\
\hline none & 631 & 48.6 \\
\hline 1.4 & 62 & 4.8 \\
\hline$\geq 5$ & 305 & 23.5 \\
\hline unknown & 300 & 23.1 \\
\hline \multicolumn{3}{|c|}{ Alcohol consumption (glasses/week) } \\
\hline none & 785 & 60.5 \\
\hline $1-4$ & 186 & 14.3 \\
\hline$\geq 5$ & 26 & 2.0 \\
\hline unknown & 301 & 23.2 \\
\hline \multicolumn{3}{|c|}{ Gestational age at intake (weeks) } \\
\hline$<8$ & $24 \mathbb{1}$ & 18.6 \\
\hline $8-12$ & 622 & 47.9 \\
\hline$\geq 12$ & 407 & 31.4 \\
\hline unknown & 28 & 2.1 \\
\hline \multicolumn{3}{|c|}{ Maternal height $(\mathrm{cm})$} \\
\hline$<150$ & 9 & 0.7 \\
\hline $150-154$ & 44 & 3.4 \\
\hline $155-159$ & 167 & 12.9 \\
\hline $160-164$ & 350 & 27.0 \\
\hline $165-169$ & 380 & 29.3 \\
\hline $170-174$ & 222 & 17.1 \\
\hline $175-179$ & 60 & 4.6 \\
\hline $180-184$ & 10 & 0.8 \\
\hline unknown & 56 & 4.3 \\
\hline
\end{tabular}

$N=1298$ 
Most women (41.4\%) were between 25 and 29 years of age at their booking visit. Together with the group of women aged between 30 to 34 years, they represented $70 \%$ of the study group. Only two percent were younger than 20 years. The youngest mother in the study was 17 years, the oldest 41 years old.

In the present study, the marital status of the participants was not specifically assessed by questionnaire, but a review of the medical records revealed a marriage percentage of approximately $96 \%$.

The educational attainment of the study group was relatively high; nearly two thirds completed high school or a postgraduate course. Women who did not finish the schooling stated, were classified one category lower. Most women of the lowest category (380/400) finished elementary household school.

More than 25\% of the enrolled women smoked before and during pregnancy. Nearly $50 \%$ were recorded as non-smokers. In analyzing these data, several considerations were made. Firstly, as mentioned, the data on smoking habits were obtained by questionnaire at two occasions. The first occasion was at the booking visit, the second at the beginning of the third trimester of pregnancy. Many women discontinued their smoking during the first two trimesters of pregnancy. The information obtained at the second occasion was therefore considered to reflect most accurately the actual smoking habits during pregnancy and consequently this information was used. Secondly, in view of the fact that smokers tend to underreport the daily number of cigarettes smoked, (which attitude is intensified during pregnancy), quantitative assessment of smoking habits was considered to be rather inaccurate. Therefore, the data on smoking habits were simply classified in four categories, i.e. smokers ( $1-4$ cigarettes per day), heavy smokers ( $\geq 5$ cigarettes per day), non-smokers or unknown. From $23.1 \%$ of the women the data on smoking habits were not available because due to personnel shortage at the outpatient departments, not all women were handed out the second questionnaire. This of course limited the group in which the influence of smoking could be analyzed.

The data on alcohol drinking habits were also classified in four catagories. Sixty percent of the women claimed not to take alcoholic beverages during pregnancy; nearly $15 \%$ used one to four glasses of alcohol per week whereas only $2 \%$ consumed more than five glasses per week. Data of $23.2 \%$ of women were missing. The considerations and problems mentioned for the smokers were also applicable to this variable.

Table 4.1 shows that most women were between 160 and 169 centimeters tall, whereas about $4 \%$ were shorter than 155 centimeters. Maternal height was obtained from data routinely noted in the medical charts. In $4.3 \%$ cases this item was missing. 
Gestational age at the first antenatal visit (in completed weeks and days) varied from five to twenty-one weeks, most women being enrolled in between the $8^{\text {th }}$ and $12^{\text {th }}$ weeks of pregnancy (Figure 4.1). Gestational age with an uncertainty of more than one week was considered "unknown".

\subsubsection{Reproductive history}

In Table 4.2 the characteristics of the reproductive history of the study group are presented. Almost one third of the total study group were primigravidae. Of the multigravida women, $19.1 \%$ experienced one or more spontaneous abortions in a previous pregnancy. Of the total group, $34.8 \%$ women were nulliparous. Almost seven percent of the mothers delivered before the $37^{\text {th }}$ week in a previous pregnancy. A little over three percent delivered a small-for-date infant. 
Trable 4.2

Characteristics of the reproductive history of the sudy group.

\begin{tabular}{|c|c|c|}
\hline Charatteristic & n & $\%$ \\
\hline \multicolumn{3}{|l|}{ Presgnancy } \\
\hline 1 & 379 & 29.2 \\
\hline 2 & 529 & 40.8 \\
\hline 3 & 253 & 19.5 \\
\hline 4 & 97 & 7.5 \\
\hline$\geq 5$ & 39 & 3.1 \\
\hline unknown & 1 & 0.1 \\
\hline \multicolumn{3}{|l|}{ Parily } \\
\hline 0 & 452 & 34.8 \\
\hline 1 & 578 & 44.5 \\
\hline 2 & 204 & 15.7 \\
\hline$\geq 3$ & 63 & 49 \\
\hline unknown & 1 & 0.1 \\
\hline \multicolumn{3}{|l|}{ Abortion } \\
\hline 0 & 1051 & 81.0 \\
\hline 1 & 189 & 14.6 \\
\hline$\geq 2$ & 58 & 4.5 \\
\hline unknown & 0 & \\
\hline \multicolumn{3}{|c|}{ Previous preterm delivery } \\
\hline 0 & 1209 & 93.1 \\
\hline 1 & 84 & 6.5 \\
\hline$\geq 2$ & 4 & 0.3 \\
\hline unknown & 1 & 0.1 \\
\hline \multicolumn{3}{|c|}{ Previous immature delivery } \\
\hline 0 & 1257 & 96.8 \\
\hline 1 & 36 & 2.8 \\
\hline$\geq 2$ & 4 & 0.3 \\
\hline unknown & 1 & 0.1 \\
\hline \multicolumn{3}{|c|}{ Previous term born small-for-date infants } \\
\hline 0 & 1254 & 96.6 \\
\hline 1 & 40 & 3.1 \\
\hline$\geq 2$ & 2 & 0.2 \\
\hline unknown & 2 & 0.2 \\
\hline \multicolumn{3}{|c|}{ Previous preterm born small-for-date infonts } \\
\hline 0 & 1281 & 98.7 \\
\hline 1 & 15 & 1.2 \\
\hline$\geq 2$ & 1 & 0.1 \\
\hline anknown & 1 & 0.1 \\
\hline
\end{tabular}

$N=1298$ 


\subsubsection{Medical risk factors}

Table 4.3 summarizes the prevalences of the assessed maternal risk factors of the study group.

In the study population, approximately half of the women experienced one or several infections of the urinary tract prior to the pregnancy at issue, i.e. the cumulative lifetime prevalence of urimary tract infections shown in Table 4.3 is $47.5 \%$. In the year preceding enrollment, $5.1 \%$ experienced an infection of the urinary tract.

Table 4.3

Medical risk factors of the study group.

\begin{tabular}{|c|c|c|}
\hline Risk factor & $\mathrm{n}$ & 喁 \\
\hline \multicolumn{3}{|c|}{ Urinary tract infection ever experienced } \\
\hline+ & 616 & 47.5 \\
\hline- & 631 & 48.6 \\
\hline unknown & 51 & 3.9 \\
\hline \multicolumn{3}{|c|}{ Urinary tract infection in preceding year } \\
\hline+ & 66 & 5.1 \\
\hline- & 1181 & 91,0 \\
\hline uniknown & 51 & 3.9 \\
\hline \multicolumn{3}{|c|}{ Previous lower genital tract infection } \\
\hline * & 366 & 28.2 \\
\hline- & 802 & 61.8 \\
\hline unknown & 130 & 10.0 \\
\hline \multicolumn{3}{|c|}{ Haemoglobin at 32 weeks (mMol/1) } \\
\hline $5.0-5.9$ & 3 & 0.2 \\
\hline 6.0 .6 .9 & 238 & 18.3 \\
\hline $7.0-7.9$ & 699 & 53.9 \\
\hline 8.0 .8 .9 & 170 & 13.1 \\
\hline 90.99 & 5 & 0.4 \\
\hline unknown & 183 & 14.1 \\
\hline \multicolumn{3}{|c|}{ Creatinine $\left(10^{-2} \mathrm{mMol} / \mathrm{l}\right)$} \\
\hline$<50$ & 114 & 8.8 \\
\hline $50-59$ & 257 & 19.8 \\
\hline $60-69$ & 134 & 10.3 \\
\hline $70-79$ & 34 & 26 \\
\hline 80.89 & 9 & 0.7 \\
\hline$\geq 90$ & 4 & 0.3 \\
\hline unknown $(\diamond)$ & 746 & 57.5 \\
\hline
\end{tabular}

(\$) The matemal senum level of creatinine was not determined at the Sine Elisabeth Clinic in Heerlen.

$\mathbb{N}=1298$ 
Previous infections of the lower genital tract, i.e. vaginitis / cervicitis and salpingitis, were recorded in $28.2 \%$. Salpingitis prior to the pregnancy at issue occurred in $1.5 \%$ of the study group. A total of 130 women did not respond to the questions regarding previously experienced infections of the lower genital tract.

At the beginning of the third trimester of pregnancy, a haemoglobin level over $8.0 \mathrm{mMol} / \mathrm{l}$ was observed in $13.1 \%$ of the study group. Only three women were anaemic. The haemoglobin levels of the majority of women ranged between $7.0-7.9 \mathrm{mMol} / \mathrm{l}$. Haemoglobin- and creatinine levels were obtained by review of medical records. In 183 women haemoglobin level was neither determined nor noted in the medical record. The maternal serum level of creatinine showed a normal distribution over the various categories. The high rate of missing values of the creatinine level $(746 / 1298)$ is due to the fact that at the outpatient department of the Sint Elisabeth Clinic in Heerlen this parameter is not determined on a routine basis.

\subsubsection{Pregnancy outcome data}

The amenorrhoea at delivery ranged from 18.7 to 44.1 weeks. The mean gestational age was $39.5 \pm 2.4$ weeks. At delivery, the median of the gestational age of the study group was 40.0 weeks. The median was calculated out of 1238 valid cases. Data of artificially interrupted $(n=14)$ and twin pregnancies $(n=12)$ were excluded as well as the pregnancies ending in a spontaneous abortion ( $n=34)$. In Figure 4.2 the distribution of the deliveries, according to gestational age is shown.

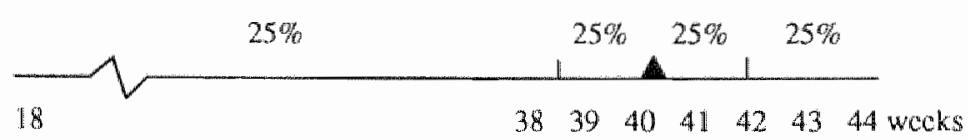

Figure 4.2

Median (A) and range of gestational age at delivery of the study group.

$N=1238$ 


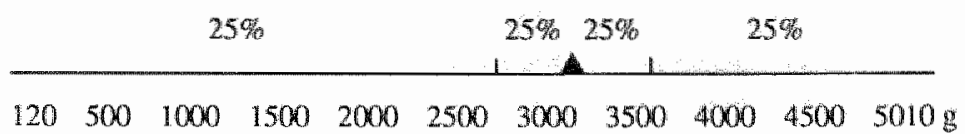

Figure 4.3

Median (A) and range of birth weight of the study group.

$\mathrm{N}=1238$

In Figure 4.3 the distribution of birth weight of all infants is presented. The median birth weight of the infants was 3290 grams. Birth weight ranged from 120 to 5010 grams. The mean birth weight was $3247.9 \pm$ $606.7 \mathrm{~g}$. Callculation was based on 1238 valid single pregnancies.

In Table 4.4 the pregnancy outcome data of the study group are presented. Preterm birth of an infant after spontaneous onset of labour occurred in $7.8 \%$ of women. A total of $107(8.2 \%)$ women experienced preterm labour in the absence of ruptured membranes. Of those, 43 (3.3\%) required intravenous tocolytic therapy. Preterm rupture of membranes was observed in $51(3.9 \%)$ of the studied pregnant women. Thirteen (1.0\%) of them were administered intravenous tocolytic therapy. Remarkably, up to 190 (14.6\%) infants were born small-for-date, according to the Amsterdam growth table. All preterm born children had a birth weight of less than $2500 \mathrm{~g}$. Of the 1298 pregnancies, 34 (2.6\%) ended in a spontaneous abortion, whereas ten fetuses died anteor intra partum between the $16^{\text {th }}$ and $28^{\text {th }}$ weeks. All fetuses born after a gestation of more than 28 weeks were live born. Pregnancy induced hypertension was observed in $6.6 \%$ of the participating women. Insulinrequiring disorders of the maternal carbohydrate metabolism were noled in $30(2.3 \%)$ gravid women. Antibiotics were used for a variety of reasons by $72(5.6 \%)$ women during pregnancy.

\subsection{Prevalence of Chlamydia trachomatis, Mycoplasma hominis, Ureaplasma urealyticum and asymptomatic bacteriuria}

The first aim of the present investigation was to determine the endocervical prevalence of Chlamydia trachomatis, Mycoplasma hominis, Ureaplasma urealyticum, and of asymptomatic bacteriuria in the sample of pregnant women studied. Up to now, in the Netherlands only limited data are available on the prevalence of these micro-organisms in women, especially in pregnant women. 
Table 4.4Pregnancy outcome dala of the sudy group.

\begin{tabular}{|c|c|c|}
\hline Outcome & In & ro \\
\hline \multicolumn{3}{|c|}{ Preterm rupture of membranes } \\
\hline$\sharp$ & 51 & 3.9 \\
\hline$\ldots$ & 1247 & 96.1 \\
\hline whinown & 0 & \\
\hline \multicolumn{3}{|l|}{ Preterm labour } \\
\hline+ & 107 & 8.2 \\
\hline- & 1191 & 91.8 \\
\hline uidknown & 0 & \\
\hline \multicolumn{3}{|c|}{ Gestational age at deliwery (weeks) } \\
\hline$<37$ & 101 & 7.8 \\
\hline$\geq 37$ & 1137 & 87.6 \\
\hline unknown & 60 & 4.6 \\
\hline \multicolumn{3}{|c|}{ Birth weight (Amsterdam growth table) } \\
\hline P<10 & 190 & 14.6 \\
\hline$P 10.89$ & 952 & 73.3 \\
\hline$P \geq 90$ & 78 & 6.0 \\
\hline unknown & 78 & 6.0 \\
\hline \multicolumn{3}{|l|}{ Birtli weight $(\mathrm{g})$} \\
\hline$<2500 \mathrm{~g}$ & 101 & 7.8 \\
\hline $22500 \mathrm{~g}$ & 1127 & 868 \\
\hline unknown & 70 & 5.4 \\
\hline \multicolumn{3}{|l|}{ Fetal survivat at birth } \\
\hline spontaneous abontion & 34 & 2.6 \\
\hline live born & 1254 & 96.6 \\
\hline ante partum ratal death & 8 & 0.6 \\
\hline intra partum fetal death & 2 & 0.2 \\
\hline unknown & 0 & \\
\hline \multicolumn{3}{|l|}{ Umbilical arterial pH } \\
\hline$<7.00$ & 12 & 0.9 \\
\hline $7.00-7.09$ & 51 & 3.9 \\
\hline $7.10-7.19$ & 303 & 23.3 \\
\hline $7.20-7.29$ & 577 & 44.5 \\
\hline $7.30-7.39$ & 234 & 18.0 \\
\hline$\geq 7.40$ & 21 & 1.6 \\
\hline unknown & 100 & 7.7 \\
\hline \multicolumn{3}{|c|}{ Pregnancy induced hypertension } \\
\hline 4 & 85 & 6.6 \\
\hline - & 1213 & 93.4 \\
\hline unknown & 0 & \\
\hline \multicolumn{3}{|l|}{ Disbetes mellitus } \\
\hline+ & 30 & 2.3 \\
\hline- & 1268 & 97.7 \\
\hline unknown & 0 & \\
\hline \multicolumn{3}{|l|}{ Use of antibiotics } \\
\hline+ & 72 & 5.6 \\
\hline- & 920 & 70.9 \\
\hline unknown & 306 & 23.6 \\
\hline
\end{tabular}

$N=1298$ 
Table 4.5

Prevalence of Chlamydia trachomatis, Mycoplasma hominss, Ureaplasma urealyticum and asymptomatic bacteriuria in the study group.

\begin{tabular}{lrr}
\hline Micro-organism & $\mathrm{n} / \mathrm{N}(\boldsymbol{})$ & \multicolumn{1}{c}{$\%$} \\
\hline Chlamydia trachomatis & $19 / 1168$ & 1.6 \\
Mycoplasma hominis & $60 / 1192$ & 5.0 \\
Ureaplasma urealyticum & $327 / 1193$ & 27.4 \\
Asymptomatic bacteriuria & $114 / 1244$ & 9.2 \\
\hline
\end{tabular}

( ) Sample size varies slighty because of non-evaluable or missing values. $\mathrm{N}=1298$

In Table 4.5, the numbers detected and corresponding rates of the micro-organisms studied and of asymptomatic bacteriuria in the total study group are presented.

The results of almost ten per cent (130/1298) of the specimens for Chlamydia trachomatis were unknown. This was partly due to specimens not received, but more frequently $(92 / 130)$ the specimens were non-evaluable due to the absence of endocervical cells. During pregnancy the cervix is highly vulnerable. Rotating a swab against the wall of the endocervix often induces cervical bleeding, hampering the attending gynaecologist in properly obtaining columnar epithelial cells. Due to logistic problems approximately $8 \%$ of the cultures for Mycoplasma hominis and Ureaplasma urealyticum were lost for evaluation. Several participating women (54/1298) did not manage to produce a urine specimen on request.

In women with a positive culture for asymptomatic bacteriuria, the uropathogens found were Escherichia coli (80/1244), Proteus mirabilis (11/1244), other Gram-negative bacteria (17/1244), Staphylococcus spp. (5/1244), and group B streptococci (1/1244).

A number of women yielded positive results for two or more of the micro-organisms studied. The presence or absence of Chlamydia trachomatis, Mycoplasma hominis, Ureaplasma urealyticum and of asymptomatic bacteriuria in the individual women is presented in Table 4.6. If any of the culture results of the micro-organisms was not available, the culture record of the woman was scored as incomplete $(n=211)$. 
Table 4.4 Pregnancy outcome data of the study group.

\begin{tabular}{|c|c|c|}
\hline Oulcome & n & 5 \\
\hline \multicolumn{3}{|c|}{ Preterm rupure of membranes } \\
\hline+ & 51 & 3.9 \\
\hline- & 1247 & 96.1 \\
\hline unknowm. & 0 & \\
\hline \multicolumn{3}{|l|}{ Preterm labour } \\
\hline+ & 107 & 8.2 \\
\hline - & 1191 & 91.8 \\
\hline unknown & 0 & \\
\hline \multicolumn{3}{|c|}{ Cintstational age at delivery (weeks) } \\
\hline$<37$ & 101 & 7.8 \\
\hline$\geq 37$ & 1137 & 87.6 \\
\hline unknown & 60 & 4.6 \\
\hline \multicolumn{3}{|c|}{ Birth weight (Amsterdam growth table) } \\
\hline$P<10$ & 190 & 14.6 \\
\hline P 10.89 & 952 & 73.3 \\
\hline$P \geq 90$ & 78 & 6.0 \\
\hline unknown & 78 & 6.0 \\
\hline \multicolumn{3}{|l|}{ Birth weight $(g)$} \\
\hline$<2500 \mathrm{~g}$ & 101 & 7.8 \\
\hline$\geq 2500 \mathrm{~g}$ & 1127 & 86.8 \\
\hline unknown & 70 & 5.4 \\
\hline \multicolumn{3}{|l|}{ Fetal survival at birth } \\
\hline spontaneouss abortion & 34 & 2.6 \\
\hline live born & 1254 & 96.6 \\
\hline ante partum fetal death & 8 & 0.6 \\
\hline intra partum fetal death & 2 & 0.2 \\
\hline unknown & 0 & \\
\hline \multicolumn{3}{|l|}{ Umbilical arterial $\mathrm{p} \mathbb{H}$} \\
\hline$<7.00$ & 12 & 0.9 \\
\hline $7.00-7.09$ & 51 & 3.9 \\
\hline $7.10-7.19$ & 303 & 23.3 \\
\hline $7.20-7.29$ & 577 & 44.5 \\
\hline $7.30-7.39$ & 234 & 18.0 \\
\hline$\geq 7.40$ & 21 & 1.6 \\
\hline unknown & 100 & 7.7 \\
\hline \multicolumn{3}{|c|}{ Pregnancy induced lyypertension } \\
\hline+ & 85 & 6.6 \\
\hline- & 1213 & 93.4 \\
\hline unknown & 0 & \\
\hline \multicolumn{3}{|l|}{ Diabetes mellitus } \\
\hline+ & 30 & 2.3 \\
\hline- & 1268 & 97.7 \\
\hline unknown & 0 & \\
\hline \multicolumn{3}{|l|}{ Use of antibiotics } \\
\hline+ & 72 & 5.6 \\
\hline- & 920 & 70.9 \\
\hline unknown & 306 & 23.6 \\
\hline
\end{tabular}

$M=1298$ 
Table 4.5

Prevalence of Chlamydia trachomatis. Mycoplaswa hominus.s. Vraplasma wealy ticum and asymptomatic bacteriuria in the study group.

\begin{tabular}{lrr}
\hline Micro-organism & $\mathrm{n} / \mathrm{N}(\diamond)$ & $\%$ \\
\hline Chlanydia trachonatis & $19 / 1168$ & 1.6 \\
Mycoplasma hominis & $60 / 1192$ & 5.0 \\
Ureaplasma ureatyticum & $327 / 1193$ & 27.4 \\
Asymptomatic bacteriuria & $114 / 1244$ & 9.2 \\
\hline
\end{tabular}

( $\diamond)$ Sample size varies slighty because of non-evaluable or missing values.

$\mathrm{N}=1298$

In Table 4.5, the numbers detected and corresponding rates of the micro-organisms studied and of asymptomatic bacteriuria in the total study group are presented.

The results of almost ten per cent (130/1298) of the specimens for Chlamydia trachomatis were unknown. This was partly due to specimens not received, but more frequently $(92 / 130)$ the specimens were non-evaluable due to the absence of endocervical cells. During pregnancy the cervix is highly vulnerable. Rotating a swab against the wall of the endocervix often induces cervical bleeding, hampering the attending gynaecologist in properly obtaining columnar epithelial cells. Due to logistic problems approximately $8 \%$ of the cultures for Mycoplasma hominis and Ureaplasma urealyticum were lost for evaluation. Several participating women (54/1298) did not manage to produce a urine specimen on request.

In women with a positive culture for asymptomatic bacteriuria, the uropathogens found were Escherichia coli (80/1244), Proteus mirabilis (11/1244), other Gram-negative bacteria (17/1244), Staphylococcus spp. (5/1244), and group B streptococci (1/1244).

A number of women yielded positive results for two or more of the micro-organisms studied. The presence or absence of Chlamydia trachomatis, Mycoplasma hominis, Ureaplasma urealyticum and of asymptomatic bacteriuria in the individual women is presented in Table 4.6. If any of the culture results of the micro-organisms was not available, the culture record of the woman was scored as incomplete $(\mathrm{n}=211)$. 
Table 4.6

Presence and absence of Chlamydia trachomatis, Mycoplasma hominis, Ureaplasma urealydicum and asymptomatic bacteriuria in the study group $(\mathrm{N}=1298)$.

\begin{tabular}{|c|c|c|c|c|c|}
\hline $\begin{array}{l}\text { Chlamydia } \\
\text { urachomatis }\end{array}$ & $\begin{array}{l}\text { Mycoplasma } \\
\text { hominis }\end{array}$ & $\begin{array}{l}\text { Ureaplasma } \\
\text { urealyticum }\end{array}$ & $\begin{array}{l}\text { Asymplomatic } \\
\text { bacteriuria }\end{array}$ & $\mathrm{n}$ & $\%$ \\
\hline * & $*$ & & & 2 & 0.2 \\
\hline * & & * & * & 2 & 0.2 \\
\hline * & & $*$ & & 3 & 0.2 \\
\hline \multirow[t]{10}{*}{ * * } & & & & 9 & 0.7 \\
\hline & * & $*$ & $*$ & 3 & 0.2 \\
\hline & * & * & & 21. & 1.6 \\
\hline & $*$ & & * & 2 & 0.2 \\
\hline & * & & & 23 & 1.8 \\
\hline & & $*$ & * & 23 & 1.8 \\
\hline & & * & & 240 & 18.5 \\
\hline & & & * & 72 & 5.5 \\
\hline & & & & 687 & 52.9 \\
\hline & & & & $211(4$ & 16.3 \\
\hline
\end{tabular}

* Micro-organism or asymptomatic bacteriuria present.

$(\diamond)$ Incomplete culture records.

4.2.1 Relation of Chlamydia trachomatis, Mycoplasma hominis, Ureaplasma urealyticum and asymptomatic bacteriuria with gestational age at delivery and birth weight

The second aim of the present study was first to delineate the extent to which the pregnancy outcome of the isolation-positive women differed from the culture-negative women in terms of decreased duration of pregnancy and birth weight. In addition, the relation of demographic, behavioural., and medical variables with these two outcomes of pregnancy was of interest.

Using bivariate cross-tabulations no differences were found between culture-positive and culture-negative mothers (Table 4.7, Table 4.8). The numbers within these two categories were almost equally distributed according to both the median gestational age at delivery and the median birth weight. 
Table 4.7

Distribution of gestational age at delivery for categories of Chlamydia trachomatis, Mycoplasma hominis, Ureaplasma urealyticum and asymptomatic bacterina

Micro-organism

Gestational age at delivery

$$
\text { n } \quad<40 w \mathrm{ks}>40 w \mathrm{ks}
$$

\section{Chlamydia trachomatis}

$\begin{array}{rrrr}+ & 19 & 8 & 11 \\ - & 1093 & 547 & 546\end{array}$

Mycoplasma hominis

$\begin{array}{rrrr}+ & 57 & 32 & 25 \\ - & 1072 & 524 & 548\end{array}$

Ureaplasma urealyticum

$\begin{array}{llll}+ & 314 & 158 & 156 \\ - & 815 & 398 & 417\end{array}$

Asymptomatic bacteriuria

$\begin{array}{rrrr}+ & 109 & 49 & 60 \\ - & 1078 & 537 & 541\end{array}$

Table 4.8

Distribution of bith weight for categories of Chlamydia rachomatis, Mycoplasma hominis, Ureaplasma urealyticum and asymptomatic bacteriuria

Micro-organism

Birth weight

n $\quad<3290 \mathrm{~g}>3290 \mathrm{~g}$

Chamydia trachomatis

$\begin{array}{rrrr}* & 19 & 9 & 10 \\ - & 1084 & 536 & 548\end{array}$

Mycoplasma hominis

$\begin{array}{rrrr}+ & 56 & 32 & 24 \\ - & 1063 & 518 & 545\end{array}$

Ureaplasma urealyticum

$\begin{array}{rrrr}+ & 314 & 160 & 154 \\ - & 806 & 390 & 416\end{array}$

Asymptomatic bacteriuria

$\begin{array}{rrrr}+ & 109 & 57 & 52 \\ - & 1068 & 522 & 546\end{array}$


4.2.2 Relation of demographic, behavioural, and medical variables with gestational age at delivery and birth weight

Of the secondary independent yariables tested, the presence of a preterm born infant in the matemal reproductive history was significantly related to a decreased gestational age in the present pregnancy. The same relation was found between the presence of a previously born, preterm small-for-date infant and gestational age less than the median. Also, as expected, placental weight was related to the gestational age of the pregnancy at issue.

Several demographic and behavioural wariables (maternal age, maternal educational attainment, smoking) were found to be significantly related to birth weight. Not surprisingly, a distinct rellation between placental weight and birth weight was observed. Also, characteristics of the maternal reproductive history (pregnancy, parity, preterm birth, previous small-for-date infants) and certain medical factors $(\mathrm{Hb}$, pregnancy induced hyperiension) were significantly related to birth weight.

Using trivariate cross-tabulations including dependent and both primary and secondary independent variables, it was observed that the presence of asymptomatic bacteriuria in women already positive for Ureaplasma urealyticum significantly decreased the gestational age. Other significant interactions between the variables tested were not observed.

\subsection{Differences in birth weight and gestational age at delivery between categories of demographic, behavioural, and medical variables}

Using one-way analysis of variance (ANOVA), means of birth weight and gestational age were compared within categories of primary and secondary independent variables. No significant association was found between the presence of Mycoplasma hominis, Ureaplasma urealyticum, asymptomatic bacteriuria and birth weight or gestational age at delivery. Variables significantly associated to birth weight and gestational age are depicted in Table 4.9. Differences within categories of maternal age, maternal length, educational attainment, smoking, haemoglobin level, and placental weight were significantly related to birth weight. Haemoglobin level and placental weight were significantly related to gestational age at delivery. Differences found between categories of placental weight versus birth weight and gestational age, were trivial and therefore not analyzed further.

In Tables 4.10 to 4.14 , the differences found between categories of secondary independent variables versus birth weight are depicted in detail. Similarly, in Tables 4.15 and 4.16, differences found between 
Table 4.9

Significant differences between categories of primary and of stcondary undependent variables callculated for birth weight and gestational age at deliwery.

Independent variable Birth weight Gestational age at delivery

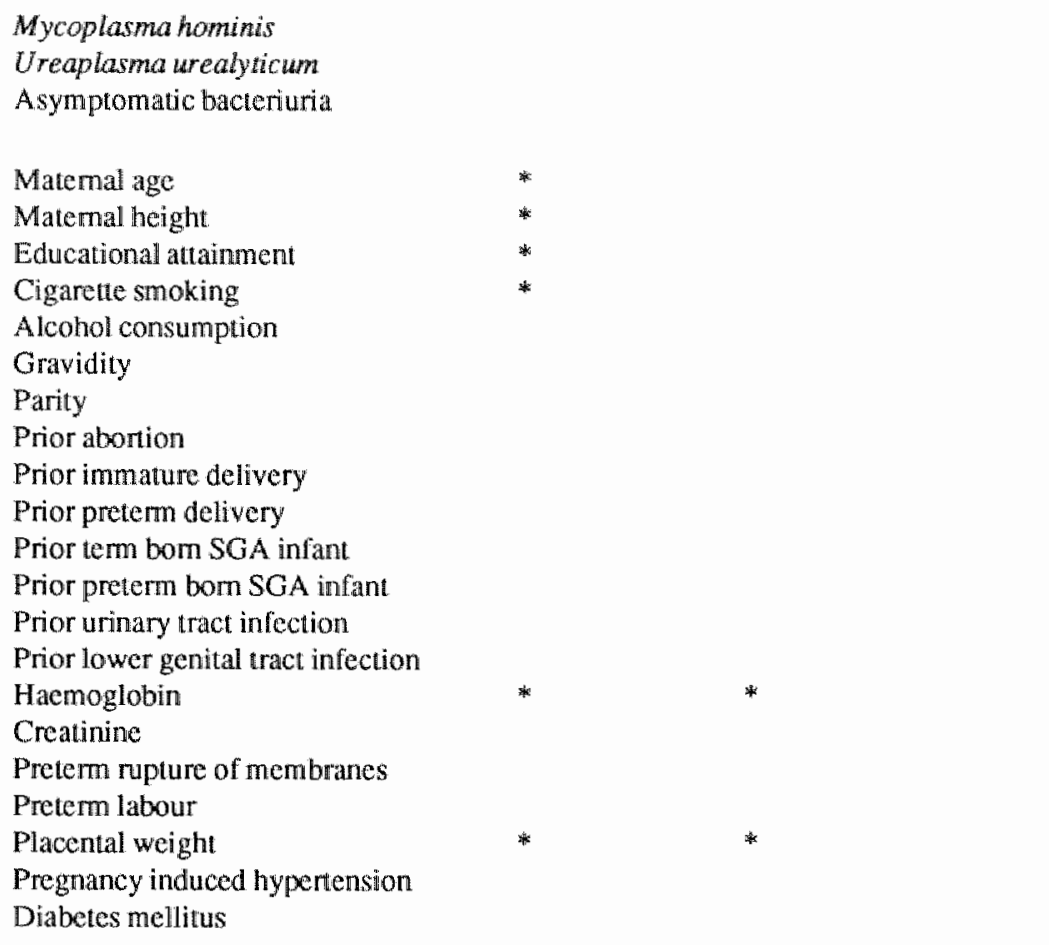

* significance $\mathrm{p}<0.05$ using one-way analysis of variance.

categories of secondary independent variables versus gestational age at delivery are shown. The Tables should be read as a matrix, i.e. categories within a dependent variable are presented both wertically and horizontally. An asterisk denotes a pair of means of categories significantly different from each other. For instance, in Table 4.10 , the mean birth weight within category 1 differs significantly from the mean within category 3 i.e. the mean birth weight of children born to heavy smokers ( $\geq 5$ cigarettes per day) is significantly less than the mean birth weight of children born to non-smokers. The means for the categories are sorted in ascending order. 
Table 4.10

Differtuces in mean birth weight between categones of smokers versus non-smokers.

\begin{tabular}{llllr}
\hline Categrory & $\begin{array}{l}\text { Cigarettes } \\
\text { (n/day) }\end{array}$ & $\begin{array}{l}\text { Binh weight } \\
\text { mean } \pm \mathrm{SD}(\mathrm{g})\end{array}$ & $\begin{array}{l}\text { Category } \\
1\end{array}$ & $\mathbb{n}$ \\
\hline 1 & $\geq 5$ & $3153 \pm 550$ & 296 \\
2 & $1-4$ & $3237 \pm 447$ & 60 \\
3 & none & $3370 \pm 478$ & $*$ & 609 \\
\hline
\end{tabular}

* Denotes pairs of categories significantly different at the 0.05 level.

Tabile 4.11

Differences in mean birth weight between categories of matemal height.

\begin{tabular}{llllr}
\hline Category & $\begin{array}{l}\text { Height } \\
(\mathrm{cm})\end{array}$ & $\begin{array}{l}\text { Birth weight } \\
\text { mean } \pm \mathrm{SD}(\mathrm{g})\end{array}$ & $\begin{array}{l}\text { Category } \\
1,2,3,4\end{array}$ & $\mathrm{n}$ \\
\hline 1 & $\leq 155$ & $3088 \pm 573$ & & 47 \\
2 & $155-159$ & $3096 \pm 614$ & & 156 \\
3 & $160-164$ & $3256 \pm 557$ & $*$ & 338 \\
4 & $170-174$ & $3272 \pm 586$ & $*$ & 209 \\
5 & $165-169$ & $3322 \pm 534$ & $*$ & 359 \\
6 & $\geq 175$ & $3466 \pm 680$ & $* * * *$ & 64 \\
\hline
\end{tabular}

* Denotes pairs of categories significantly different at the 0.05 level.

The mean birth weight of infants of heavy smokers differed significantly from the mean birth weight of infants of non-smokers. At delivery, infants of heavy smokers were on the average $217 \mathrm{~g}$ lighter compared to the birth weight of infants of non-smokers. No difference in the gestational age at delivery between smokers versus non-smokers was observed.

Women shorter than $159 \mathrm{~cm}$ tended to give birth to smaller children compared to mothers with a height of $160 \mathrm{~cm}$ or more. The mean birth weight for the six categories of maternal height ranged from $3088 \mathrm{~g}$ for the mothers shorter than $155 \mathrm{~cm}$ to $3466 \mathrm{~g}$ for mothers taller than $175 \mathrm{~cm}$. Due to the small number of observations in category 1 , significant differences were only found between the mean birth weight within category 2 and categories $3,4,5$ and 6 . 
Table 4.12

Differences in mean birth weight between categories of matemal haenoglobin level.

\begin{tabular}{lllll}
\hline Category & $\begin{array}{l}\text { Ho } \\
(\mathrm{mMolN})\end{array}$ & $\begin{array}{l}\text { Birth weight } \\
\text { mean } \pm \mathrm{SD}(\mathrm{g})\end{array}$ & $\begin{array}{l}\text { Category } \\
1\end{array}$ & $\mathrm{n}$ \\
\hline 1 & 28.0 & $3135 \pm 629$ & & 167 \\
2 & $6.0-7.9$ & $3308 \pm 516$ & $*$ & 687 \\
3 & $\leq 5.9$ & $3357 \pm 520$ & $*$ & 234 \\
\hline
\end{tabular}

* Denotes pairs of categories significantly different at the 0.05 level.

Table 4.13

Differences in mean birth weight between categories of maternal age.

\begin{tabular}{|c|c|c|c|c|}
\hline Category & $\begin{array}{l}\text { Age } \\
\text { (years) }\end{array}$ & $\begin{array}{l}\text { Birth weight } \\
\text { mean } \pm \mathrm{SD}(\mathrm{g})\end{array}$ & $\begin{array}{l}\text { Callegory } \\
1\end{array}$ & $\mathbb{1}$ \\
\hline 1 & $20-24$ & $3133 \pm 605$ & & 198 \\
\hline 2 & $<20$ & $3191 \pm 475$ & & 28 \\
\hline 3 & $25-29$ & $3272 \pm 597$ & & 531 \\
\hline 4 & $\geq 35$ & $3292 \pm 518$ & & 100 \\
\hline 5 & $30-34$ & $3310 \pm 567$ & * & 373 \\
\hline
\end{tabular}

* Denotes pairs of categories significantly different at the 0.05 level.

A maternal haemoglobin level of $\geq 8.0 \mathrm{mMol} / \mathrm{L}$ was associated with a significant lower birth weight as compared to a haemoglobin level of $6.0-7.9 \mathrm{mMol} / \mathrm{l}$. Also the mean birth weight within category 1 differed significantly from the mean of women with a $\mathrm{Hb}$ below $5.9 \mathrm{mMol} / \mathrm{l}$. Interestingly enough, women with a $\mathrm{Hb}$ below $5.9 \mathrm{mMol} / \mathrm{l}$ delivered babies with the greatest mean birth weight. A high level of haemoglobin was observed approximately two times more often than a pregnancy induced hypertensive syndrome in the study group (Table 4.4).

Although there was a trend towards increasing mean birth weight according to maternal age, (compare categories 1,3 and 5), the only significant difference in mean birth weight was noted between infants of mothers of 20-24 years of age compared to infants of mothers between 30-34 years. The mean birth weight within categories 2 and 4 did not differ significantly from the others, most likely due to the relatively low count in both categories. 
Table 4. 14

Differences in mean birth weight between categories of matemal educational attainment.

\begin{tabular}{lllll}
\hline Catcgory & $\begin{array}{l}\text { Educational } \\
\text { attainment }\end{array}$ & $\begin{array}{l}\text { Birth weight } \\
\text { mean } \pm \mathrm{SD}(\mathrm{g})\end{array}$ & $\begin{array}{l}\text { Category } \\
1\end{array}$ & $\mathrm{n}$ \\
\hline 1 & $<$ high school & $3185 \pm 630$ & & 372 \\
2 & high school & $3271 \pm 543$ & & 444 \\
3 & $>$ high school & $3330 \pm 580$ & $*$ & 337 \\
\hline
\end{tabular}

* Denotes pairs of categories significantly different at the 0,05 level.

Table 4.15

Differences in mean gestational age at delivery between categories of matemal haemoglobin level.

\begin{tabular}{lllll}
\hline Calegory & $\begin{array}{l}\mathrm{Hb} \\
(\mathrm{mMol} / \mathrm{l})\end{array}$ & $\begin{array}{l}\text { Gestational age } \\
\text { mean } \pm \mathrm{SD}(\mathrm{wk})\end{array}$ & $\begin{array}{l}\text { Category } \\
1\end{array}$ & $\mathrm{n}$ \\
\hline 1 & $\geq 8.0$ & $39.29 \pm \mathbb{1 1 . 9 1}$ & 172 \\
2 & $\leq 5.9$ & $39.72 \pm 1.99$ & & 235 \\
3 & $6.0-7.9$ & $39.78 \pm 1.77$ & $*$ & 688 \\
\hline
\end{tabular}

* Denotes pairs of categories significantly different at the 0.05 level.

Birth weight tended to increase with maternal schooling. However, a significant difference was only noted in infants born to mothers with a relatively low educational attainment (category 1), compared to infants born to mothers who completed a vocational training after finishing high school.

Less striking than the difference in birth weight according to categories of maternal $\mathrm{Hb}$, a high serum level of maternal haemoglobin $(\geq 8.0$ $\mathrm{mMol} / \mathrm{l})$ was also associated with a shorter gestational age than a $\mathrm{Hb}$ in a normal range $(6.0-7.9 \mathrm{mMol} / \mathrm{l})$. 
4.3.1 Further investigation of demographic, behavioural and medical variables

In the first set of statistical analyses, (paragraph 4.3, Table 4.9), none of the micro-organisms studied (i.e. Mycoplasma hominis, Ureaplasma urealyticum or asymptomatic bacteriuria) were directly associated to decreased birth weight or gestational age at delivery in one-way analysis of variance. Several demographic, behavioural and medical variables however were identified as being related to decreased birth weight and prematurity.

To determine if the associations found in the preceding paragraph were still present considering all selected independent variables at the same time, they were entered in multiple linear regression analyses. Multiple linear regression analyses were performed with birth weight and gestational age as dependent variables. In the same way, logistic regression analysis was performed with birth percentile as dependent variable.

In addition this procedure allowed prediction of birth weight, gestational age at delivery or birth percentile according to the regression equation:

$$
\begin{aligned}
& y_{d}=a+b_{1} x_{1}+\ldots .+b_{n} x_{n}+u_{d} \\
& y_{d}=\text { estimated value of dependent variable } \\
& d=1 \text { birth weight } \\
& d=2 \text { gestational age at delivery } \\
& d=3 \text { birth percentile } \\
& a=\text { regression constant (intercept) } \\
& x_{1}, \ldots, x_{n}=\text { independent variables } \\
& b_{1}, \ldots, b_{n}=\text { regression coefficient } \\
& u_{d}=\text { error }
\end{aligned}
$$

In Table 4.17 the independent variables significantly related to birth weight in the multiple linear regression analysis are presented including the corresponding regression coefficients, standard error and stand ardized regression coefficients (beta). Also this Table allows prediction of the estimated birth weight for the infant of an individual mother in the study group by considering the contribution of each of the significant independent variables present. The standardized regression coefficient represents the relative predictive strength of each independent variable. The regression equation mentioned above allows estimation of the birth weight of an infant born to a given mother of the study group. Supposing she smoked during her second pregnancy and already had a smallfor-date child, the birth weight of her next child would be $2535.4 \mathrm{~g}$. (Birth weight $=3128.8-198.2+128.1-523.3=2535.4 \mathrm{~g}$ ).

As in the ANOVA, maternal smoking was identified as an important predictor of decreased birth weight. Also, presence of a small-for-date infant in the maternall reproductive history predicted decreased birth 
Table 4.17

Independent variables significantly related to birth weight $(\mathrm{g})$ by multiple linear regression analysis, including corresponding regression coefficients, Standard error, and standardized regression coefficients (beta).

\begin{tabular}{lcrr}
\hline $\begin{array}{l}\text { Independent } \\
\text { variable }\end{array}$ & $\begin{array}{c}\text { regression } \\
\text { coefficient }\end{array}$ & $\mathrm{SE}$ & beta \\
\hline Matcmal age & 69.7 & & \\
Matemal height & 134.9 & 99.9 & 0.046 \\
Educational attainment & 53.3 & 40.8 & 0.043 \\
Cigaretle smoking & $-198.2^{*}$ & 39.6 & -0.164 \\
Parity $(\geq 1)$ & $128.1^{*}$ & 40.3 & 0.105 \\
Previous small-for-date & $-523.3^{*}$ & 106.2 & -0.160 \\
Haemoglobin ( $\geq 8.0 \mathrm{mMol} / 1)$ & $-196.7^{*}$ & 51.3 & -0.123 \\
& & & \\
Regression constant & 3128.8 & 105.2 & \\
\hline
\end{tabular}

* Regression coefficients significant at the $p<0.05$ level.

$R^{2}=0.096$

weight. Evaluated by the standardized regression coefficients, both variables almost equally predicted decreased birth weight. As expected, parity was positively related to birth weight. A high level of haemoglobin was the weakest significant negative predictor of birth weight. In multiple linear regression analysis, maternal age, height, and schooling positively contributed to birth weight, but a significant level was not reached.

The two independent variables significantly associated with gestational age at delivery were previous preterm labour and a high level of serum creatinine. Both were negative predictors of the final gestational age. Of the two, previous preterm labour was the stronger predictor. In Table 4.18 the independent variables tested are presented including the corresponding regression coefficients and standardized regression coefficients.

Using logistic regression analysis, with birth percentile as dependent variable, independent wariables significantly found to be associated were pregnancy induced hypertension, smoking, and the presence of a small-for-date child (Table 4.19).

As in multiple linear regression analysis with birth weight as dependent variable, matemal smoking and the presence of a small-for-date child had a negative predictive value in estimating birth percentile. The most 
Table 4.18

Independent variables significantly related to gestational age at delivery (wks) by multiple linear regression analysis, including cornesponding regression coefficients, standard error, and standardized regression coefficients (beta).

\begin{tabular}{lccc}
\hline $\begin{array}{l}\text { Independent } \\
\text { variable }\end{array}$ & $\begin{array}{l}\text { regression } \\
\text { coefficient }\end{array}$ & $\mathrm{SE}$ & beta \\
\hline Matemal height & 2.0 & 1.7 & 0.060 \\
Matemal age & -0.8 & 0.9 & -0.045 \\
Educational attainment & 0.1 & 0.8 & 0.005 \\
Cigarette smoking & -0.2 & 0.7 & -0.012 \\
Haemoglobin ( $\geq 8.0 \mathrm{mMol} /$ ) & -1.4 & 0.9 & -0.073 \\
Preterm labour & $-3.1 *$ & 1.3 & -0.125 \\
Serum creatinine & $-1.6 *$ & 0.7 & -0.107 \\
& & & \\
Regression constant & 37.6 & 1.9 & \\
\hline
\end{tabular}

* Regression coefficients significant at the $p<0.05$ level.

$\mathrm{R}^{2}=0.078$

Table 4.19

Independent variables significantly related to birth percentile according to the Amsterdam growth table by logistic regression analysis, uncluding corresponding regression coefficients, standard error, and standardized regression coefficients (beta).

\begin{tabular}{lccc}
\hline $\begin{array}{l}\text { Independent } \\
\text { variable }\end{array}$ & $\begin{array}{l}\text { regression } \\
\text { coefficient }\end{array}$ & SE & beta \\
\hline Matemal age & 3.1 & 2.3 & 0.044 \\
Matemal height & 4.4 & 4.5 & 0.031 \\
Educational attainment & 1.9 & 1.9 & 0.031 \\
Cigarette smoking & $-9.2^{*}$ & 1.9 & -0.158 \\
Previous small-for-date & $-26.1 *$ & 5.0 & -0.165 \\
Haemoglobin ( 28.0 mMol/1) & -4.8 & 2.5 & -0.062 \\
Pregnancy induced hypertension & $-14.2 *$ & 3.8 & -0.121 \\
& & & \\
Regression constant & 41.7 & 5.1 & \\
\hline
\end{tabular}

* Regression coefficients significant at the $p<0.05$ level.

$\mathrm{R}^{2}=0.088$ 
prominent variable in estimating birth percentile was the presence of a small-for-date child in the maternal obstetrical history. Also, pregnancy-induced hypertension negatively predicted birth percentile.

In summary, neither in the bivariate analyses and one-way ANOVA, nor in the multiple linear regression analyses of the available data, were Mycoplasma hominis, Ureaplasma urealyticum and asymptomatic bacteriuria directly associated with preterm birth and decreased birth weight. This finding was confirmed in logistic regression analysis. Chlamydia trachomatisshowed no relation with birth weight or with gestational age at delivery in bivariate analysis. Several of the secondary independent wariables however were associated with these two outcomes of pregnancy.

As mentioned earlier, however, trivariate analysis showed that asymptomatic bacteriuria in Ureaplasma urealyticum-positive women was associated with a significant decrease in birth weight.

\subsection{Chlamydia trachomatis}

In the study group described in paragraph $4.1,1.6 \%$ (19/1168) women were found to have a cervical Chlamydia trachomatis infection in the first trimester of pregnancy. Unfortunately, this number was found to be too small to allow reliable statistical analysis of the data. The main problem was constituted by the number of confounding variables needed to control for. Therefore, in an attempt to avoid the same error as has been made in many of the previous studies, it was decided to present the data of the Chlamydia trachomatis positive women in a descriptive way, rather than to subject them to statistical analyses. Clearly, in this way definite conclusions cannot be drawn, but trends might be seen. Detailed case reports of all nineteen women who were found positive for Chlamydia trachomatis are presented in addendum 4. These reports include individual demographic, behavioural, medical as well as pregnancy outcome datal. An overview is presented in this paragraph.

In Table 4.20 the demographic characteristics of the Chlamydia trachomatis-positive women are presented. In order to enable a rough comparison with the study group, the numbers of the corresponding characteristics of the study group (which already have been presented in Table $4.1)$, are presented as well.

In the present study, the ages of the Chlamydia trachomatis-positive women ranged from 20 to 31 years. Within this range, the distribution according to maternal age was practically equally divided over the different years (addendum 4). 
Table 4,20

Characteristics of Chlamydia trachomatis-positive women (n) and of tho total swudy group $\left(\mathbf{n}^{\infty}\right)$.

\begin{tabular}{|c|c|c|}
\hline Characteristic & $\mathrm{n}$ & $n^{\infty}$ \\
\hline \multicolumn{3}{|l|}{ Age (years) } \\
\hline$<20$ & 0 & 28 \\
\hline $20-24$ & 7 & 200 \\
\hline $25-29$ & 9 & 537 \\
\hline $30-34$ & 3 & 377 \\
\hline $35-39$ & 0 & 100 \\
\hline$\geq 40$ & 0 & 2 \\
\hline unknown & 0 & 54 \\
\hline \multicolumn{3}{|c|}{ Educational attainment } \\
\hline$<$ high school & 12 & 400 \\
\hline ligh school & 2 & 472 \\
\hline high school & 4 & 357 \\
\hline unknown & 1 & 69 \\
\hline \multicolumn{3}{|c|}{ Cigarette smoking (cigarettes/day) } \\
\hline none & $\mathbb{1}$ & 631 \\
\hline $1-4$ & 2 & 62 \\
\hline$\geq 5$ & 6 & 305 \\
\hline unknown & 0 & 300 \\
\hline \multicolumn{3}{|c|}{ Alcohol consumption (glasses/week) } \\
\hline none & 17 & 785 \\
\hline $1-4$ & 2 & 186 \\
\hline$\geq 5$ & 0 & 26 \\
\hline unknown & 0 & 301 \\
\hline \multicolumn{3}{|c|}{ Amenorrhoea at intake (weeks) } \\
\hline$<8$ & 3 & 241 \\
\hline $8-12$ & 8 & 622 \\
\hline$\geq 12$ & 8 & 407 \\
\hline wnknown & 0 & 28 \\
\hline \multicolumn{3}{|c|}{ Maternal height (cm) } \\
\hline$<150$ & 0 & 9 \\
\hline $150-154$ & 1 & 44 \\
\hline $155-159$ & 2 & 167 \\
\hline $160-164$ & 6 & 350 \\
\hline $165-169$ & 8 & 380 \\
\hline $170-174$ & 1 & 222 \\
\hline $175-179$ & 1 & 60 \\
\hline $180-184$ & 0 & 10 \\
\hline unknown & 0 & 56 \\
\hline
\end{tabular}

$N=19$

$N^{2}=1298$ 
In earlier studies, the matemal welfare status (represented by maternal educational attainment, employment, public assistance) was found to be inversely related to the prevalence of Chlamydia trachomatis. A low welfare status predicted the presence of Chlamydia trachomatis. In this study, maternal educational attainment was chosen as the most reliable indicator of welfare. Eight of the Chlamydia trachomatis-positive women completed elementary household school, four completed advanced elementary education, two finished high school, three followed a high vocational training and one completed a training at the university. The schooling of one individual was unknown. Remarkably enough, of the eighteen women with a documented schooling, twelve completed a schooling of a level less than high school. In the total study group, $64 \%$ of the women completed high school or a postgraduate course.

This study primarily focussed on the contribution of maternal urogenital micro-organisms to the presence of preterm birth and decreased birth weight. It is of importance to control for other variables also associated with these two outcomes of pregnancy. In this respect, maternal behavioural characteristics have been associated with the presence of small-for-dates. Smoking, and to a less extent, alcohol consumption during pregnancy are known to contribute to a decreased birth weight. The majority of women were non-smokers $(11 / 19)$ as evaluated at the beginning of the third trimester of pregnancy. Of the smokers, six out of eight smoked more than ten (range, 10-17) cigarettes per day. Since people tend to underestimate their number of cigarettes smoked a day, the real number is probably higher. Hardly any of the women consumed alcohol during their pregnancy; the two who did took one glass a week. The gestational age at the booking visit varied from the $6^{\text {th }}$ to the $15^{\text {th }}$ week. Most women were screened after the $8^{\text {th }}$ week of gestation.

The organisms studied being sexually transmissible and capable of causing an ascending infection of the female genital tract, the history of prior uro-genital infections might be important (Table 4.21). Four of the women experienced recurrent non-specific vaginitis/cervicitis, whereas two individuals admitted to an infection of the upper genital tract. Remarkably, one of the two (being pregnant for the fifth time), after experiencing a bilateral salpingitis, had two consecutive miscarriages and delivered prematurely after her third pregnancy. The other one conceived after a long period of infertility at the age of 30 . A symptomatic infection of the lower urinary tract prior to the pregnancy at issue was experienced by eight women.

The reproductive history of the nineteen women in whom the presence of cervical Chlamydia trachomatis was detected, is summarized in Table 4.22 . The numbers of the corresponding characteristics of the total study group are noted as well. 


\section{Table 4.21}

Uro-genital infections in the history of Chasmydia trachomatio-positive women.

\begin{tabular}{ll}
\hline Infection & $\mathrm{n}$ \\
\hline vaginitis/cervicitis & 4 \\
salpingitis & 2 \\
symptomatic UTI & 8 \\
\hline
\end{tabular}

Table 4.22

Characteristics of the reproductive history of Chlamydiat trachomatis-positive wo-

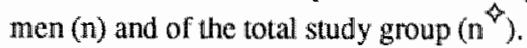

\begin{tabular}{|c|c|c|}
\hline Characteristic & $\mathrm{n}$ & $\mathrm{n}^{8}$ \\
\hline \multicolumn{3}{|l|}{ Parity } \\
\hline 0 & 12 & 452 \\
\hline 1 & 3 & 578 \\
\hline 2 & 3 & 204 \\
\hline$\geq 3$ & 1 & 63 \\
\hline unknown & 0 & 1 \\
\hline \multicolumn{3}{|l|}{ Abortion } \\
\hline 0 & 18 & 1051 \\
\hline 1 & 0 & 189 \\
\hline$\geq 2$ & 1 & 58 \\
\hline unknown & 0 & 0 \\
\hline \multicolumn{3}{|c|}{ Previous preterm delivery } \\
\hline 0 & 18 & 1209 \\
\hline 1 & 1 & 84 \\
\hline$\geq 2$ & 0 & 4 \\
\hline unknown & 0 & 1 \\
\hline
\end{tabular}

Twelve out of the nineteen women were in their first pregnancy. Among the others, one woman miscarried twice before and delivered prematurely after her third pregnancy. The reproductive history of the other multiparous women revealed neither preterm born infants nor small-fordate born children. The majority $(12 / 19)$ of Chlamydia trachomatis- 
Table 4,23 Pregnancy outcome data of Chlamydia trachomals-positive women (n) and of the wial study group ( $\mathrm{n}^{4}$ ).

Outcome $\quad n \quad n$

\section{Preterm rupture of membranes}

$+$

Preterm labour

Haemoglohin at 32 weeks (mMoll/n)

$18 \quad 1191$

$$
\begin{aligned}
& <6.0 \\
& 6.07 .9 \\
& \geq 8.0
\end{aligned}
$$

Gestational age at delivery (weeks)

$$
<37
$$

$\geq 37$

Birth weight (Amsterdam growth table)

$$
\begin{aligned}
& P<10 \\
& P 10.89 \\
& P \geq 90
\end{aligned}
$$

$\begin{array}{rr}0 & 101 \\ 19 & 1137 \\ 0 & 60 \\ & \\ 3 & 190 \\ 14 & 952 \\ 2 & 78\end{array}$

Birth weight (g)

$$
\begin{aligned}
& <2500 \\
& \geq 2500 \\
& \text { unknown }
\end{aligned}
$$

Fetal survival at birth

spontaneous abortion

$0 \quad 34$

live born

ante partum felal death

1254

intra partum fetal death

Umbilical arterial $\mathrm{pH}$

$$
<7.00
$$

$7.00-7.09$

$7.10-7.19$

7.20 .7 .29

$7.30-7.39$

$\geq 7.40$

$0 \quad 21$

unknown

Pregnancy induced hypertension

$+$

Diabetes mellitus

$+$

$0 \quad 30$

-

19

1268

Use of antibiotics

$\begin{array}{lrr}+ & 0 & 72 \\ - & 19 & 920 \\ \text { unknown } & 0 & 306\end{array}$

$N=19$

$N^{\diamond}=1298$ 
positive women being pregnant for the first time is in accordance with the findings in other studies. Of the Chlamydia trachomatis-negative women in the present study, $34.4 \%$ were nulliparous.

The relevant data on the course and outcome of the Chlamydia trachomatis-positive women and of the total study group are presented in Table 4.23.

All women carried a singleton pregnancy. None of the gestations were complicated by pregnancy-induced hypertension or a disorder of the maternal serum glucose level. Apart from two women who were prescribed iron during the last trimester because of a haemoglobin level below $7 \mathrm{mMol} / \mathrm{L}$, no drugs were used by this group during pregnancy. All women completed their pregnancy to term. However, one multiparous women was admitted to the hospital in the $28^{\text {th }}$ week of her pregnancy because of premature labour. During the next two weeks, she was successfully treated by intravenous tocolytic therapy after which she was dismissed. Eventually she delivered spontaneously at 38.5 weeks. Both of her previous pregnancies had been uneventful.

All babies were live born. Although the birth weight of all infants was over $2500 \mathrm{~g}$, three of them were small-for-date according to the Amsterdam growth table $\left(\mathrm{P}_{<10}\right)$. On the other hand, two infants scored a percentile of over 90 on the same grow th table. Two children were born with a low pH (i.e. below 7.10) of the umbilical artery. This was most probably due to entrapment of the umbilical cord during delivery.

Several women also yielded positive results for Mycoplasma hominis, Ureaplasma urealyticum or asymptomatic bacteriuria as shown in Table 4.24 .

Table 4.24

Number of posituve cultures for Mycoplasma hominis, Ureaplasma urealyticam and asymptomatic bacteriuria in Chlamydia trachomatis-positive women ( $\diamond)$.

\begin{tabular}{llll}
\hline Micro-organism & $\begin{array}{l}\text { Mycoplasma } \\
\text { hominis }\end{array}$ & $\begin{array}{l}\text { Ureaplasma } \\
\text { urealyticum }\end{array}$ & $\begin{array}{l}\text { Asymptomalic } \\
\text { bacteriuria }\end{array}$ \\
Chlamydiatrachomatis & $3 / 17$ & $5 / 17$ & $2 / 18$ \\
\hline
\end{tabular}

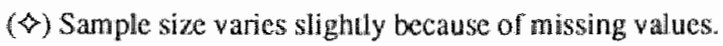


Most of these women were positive for two of the micro-organisms studied. However, two women positive for asymptomatic bacteriuria also were positive for Chlamydia trachomatis as well as for Ureaplasma urealyticum (data not shown).

In conclusion, in this study, women positive for Chlamydia trachomatis tended to have a lower educational attainment compared to the total study group. Age did not appear to be an important indicator for the presence of Chlamydia trachomatis; with the exception of women younger than 20 years, the micro-organism was evenly distributed among the different age groups. Remarkably enough, twelve of the nineteen women were nulliparous. The course and pregnancy outcome of this group of women, in terms of gestational age at delivery and birth weight, did not appear to be influenced in a negative way by the presence of cervical Chlamydia trachomatis. 


\section{Summary and Discussion}

In the last three decades neonatal mortality rates have been reduced, mainly by increased survival of term born infants. At present, the most prominent causes of neonatal death and morbidity are constituted by prematurity and birth weight small-for-date.

Micro-organisms present in the maternal urogenital tract have recently been added to the factors that have been considered to contribute to prematurity and birth weight small-for-gestational-age. Micro-organisms implicated include Chlamydia trachomatis, Mycoplasma hominis, Ureaplasma urealyticum, and uropathogens causing asymptomatic bacteriuria. However, the results of studies as to whether or not any of these micro-organisms are causally related to adverse pregnancy outcome are inconclusive. This is partly due to the incomplete understanding of the biological mechanisms underlying maternal cervical infections which would lead to prematurity and birth weight small-for-date, partly also because of the fact that the results of these investigations seem to vary with the population studied.

Considering the apparently population-dependent importance of Chlamydia trachomatis, Mycoplasma hominis, Ureaplasma urealyticum, and asymptomatic bacteriuria and considering the absence of data on the impact of these micro-organisms on pregnant Dutch women, this study was initiated.

A prospective epidemiological study of pregnant women was designed to address the questions mentioned. It was clear from the start that given the expected prevalences of the genital micro-organisms and of asymptomatic bacteriuria, a large study population, estimated at 2000 women, would be necessary to obtain statistically reliable answers. This could only be realised in a multi-centre study.

The success of such a large multi-centre epidemiological study depends on the discipline and cooperation of all participants and, in addition, on the logistic support. On both these essential facets of the study, the optimal level could not be reached. Nevertheless, although the number of women aimed for was not reached, the present study represents one of the largest studies on obstetrical epidemiology in the Netherlands. With exception of the data on Chlamydia trachomatis, sufficient data were obtained to allow reliable statistical analysis with valid conclusions. 
The present investigation revealed a prevalence of $1.6 \%$ for Chlamydia trachomatis, $5.0 \%$ for Mycoplasma hominis, $27.4 \%$ for Ureaplasma urealyticum and $9.2 \%$ for asymptomatic bacteriuria. The detected prevalence of the three genital micro-organisms tended towards the lower end of the range of rates found in other studies [chapter 2, Table 2.2, 2.5]. Recently however, in a similar pregnant population in Belgium, the same rate of Ureaplasma urealyticum was found [1]. The mutual proportions of the prevalences were in accordance with the proportions found elsewhere. The prevalence of asymptomatic bacteriuria was at the higher end of the expected range.

The differences in prevalence reported in the different studies might mainly be ascribed to differences in characteristics of the population studied and in the detection methods used.

As for the different detection methods, the culture techniques for asymptomatic bacteriuria and the genital mycoplasmata have been practically unchanged over the years, but the detection modalities for Chlamydia trachomatis have evolved greatly. Culture techniques (formerly regarded as the gold standard) are gradually being replaced by non-culture methods. The direct immunofluorescence technique used in this study (MicroTrak, Syva) is a well established, non-cultural method for detecting Chlamydia trachomatis. In well trained hands the sensitivity of the test reaches approximately $95 \%$, the specificity $94-99 \%$. Although several investigators have used 5 , or even one, apple-green fluorescent particle(s) as the cut-off point for a positive result, in this study, the cut-off point has been 10 fluorescent particles as recommended by the manufacturer. The chances of false positive results will therefore be negligible. Had a cut-off point of 5 fluorescent particles been used, results of this study would not have been changed dramatically; only two more women would have been added to the total. In addition, the direct immunofluorescence test offers the possibility of assessing the quality of the specimen to be examined. Subsequently, acellular specimens were discarded as non-evaluable. Using other techniques, these specimens would have been classified as negative.

With regard to the composition of the present study group it is obvious that it differed in several aspects from, for example, the populations studied in the USA. In the most important American studies pregnant teenagers constituted $23 \%$ to $29 \%$ of the study population $[2,3]$, whereas in the current investigation only $2.2 \%$ of the participating mothers were adolescents. Also, in the present study, the relative "older age" of the participating women was reflected in the average educational attainment. No other investigation of this kind reported a comparable high level of maternal schooling. Not surprisingly, a single marital status was observed far more often in the populations abroad. The percentages 
obtained in the reproductive history of the present study group, are consistent with the rates of nulliparous women in some [3], but not in all studies [4]. Noteworthy, in the study of Berman et al. [3], 25\% of the women screened were less than 20 years of age. In the latter study $46 \%-52 \%$ of the women studied were nulliparous compared to $34.8 \%$ in the present study.

In previous studies, age was found to be inversely related to the prevalence of Chlamydia trachomatis. In general, the highest prevalence was found in young women, aged 15 to 21 , whereas a strong decrease was observed thereafter $[3,5]$. The comparatively low prevalence in this study might partially be explained by the relative older age of the participants. In that respect, it would be interesting to compare the detected prevalence with the prevalence of Chlamydia trachomatis among non-pregnant women (teenagers as well as adults) in the same catchment area. Unfortunately, these figures are not available. At the outpatient department for venereal diseases of the University Hospital in Maastricht in the first six months of 1989,3 out of 38 individuals (male and female) were found positive for Chlamydia trachomatis. (Prof. dr W.J.B.M. van der Staak, personal communication). Obviously, since these individuals constitute a highly selected group of people, the figures mentioned are not directly comparable to the figures found in this study. They merely indicate that sexually transmitted diseases are not a common problem in this part of the Netherlands.

The second objective of this study was to relate the presence of the urogenital micro-organisms along with demographic, behavioural and medical factors in the pregnant women to birth weight and gestational age at delivery. In all calculations, birth weight and gestational age at delivery were dichotomised according to the median. Median values for gestational age at delivery (40.0 weeks) as well as for birth weight $(3290 \mathrm{~g})$, were in line with generally accepted values. These results underscore the validity of the data obtained in this study.

None of the micro-organisms studied influenced the pregnancy outcome directly. Using trivariate analysis we were able to show that the presence of asymptomatic bacteriuria in women also positive for Ureaplasma urealyticum resulted in a significant decrease in birth weight. However, neither in multiple linear regression analysis nor in logistic regression analysis was this relation confirmed. Using one-way analysis of variance, maternal age, heigth, educational attainment, smoking, and haemoglobin level were significantly related to birth weight. Compared to those of non-smokers, infants born to smokers were on the average $217 \mathrm{~g}$ lighter. Children born to young mothers (20-24 years) were lighter compared to children born to mothers aged 30-34 years. The most plausible explanation for this difference is the likelihood of in- 
creasing parity with increasing maternal age. This presumption is illustrated by Table 5.1 , in which the number of women within categories of maternall age are cross-tabulated against parity (compare nulliparae wersus primiparae). Categories were sorted by increasing age.

Table 5.1

Number of women within categories of matemal age sorted by parity.

\begin{tabular}{|c|c|c|c|c|c|}
\hline Category & $\begin{array}{l}\text { Age } \\
\text { (years) }\end{array}$ & $\begin{array}{l}\text { Parity } \\
0\end{array}$ & 1 & 2 & $\geq 3$ \\
\hline 2 & $<20$ & 15 & 10 & 2 & 1 \\
\hline 1 & $20-24$ & 98 & 79 & 19 & 2 \\
\hline 3 & $25-29$ & 184 & 249 & 80 & 18 \\
\hline 5 & $30-34$ & 106 & 177 & 64 & 26 \\
\hline 4 & $\geq 35$ & 18 & 42 & 26 & 14 \\
\hline
\end{tabular}

Also, tall mothers and mothers with a high educational attainment gave birth to significantly heavier children compared to short mothers and mothers with a low level of schooling. A Hb level of $\geq 8.0 \mathrm{mMol} / \mathrm{l}$ at the beginning of the third trimester of pregnancy was associated with a lower birth weight compared to Hb levels in a normal range. This finding is in accordance with the results of Knottnerus et al. [6], who not only found a positive relationship between a maternal $\mathrm{Hb}$ of $\geq 8.0$ $\mathrm{mMol} / \mathrm{l}$ at the beginning of the third trimester of pregnancy and low birth weight but also with preterm birth. Women in their study were recruited from the same catchment area as in the present investigation. Entering all secondary independent variables into multiple linear regression analysis, smoking, $\mathrm{Hb}$, and presence of a small-for-date infant in the maternal reproductive history were associated with decreased birth weight. Using one-way analysis of variance, maternal haemoglobin level, as measured at the beginning of the third trimester of pregnancy, was related to gestational age. $\mathrm{Hb}$ of $\geq 8.0 \mathrm{mMol} / \mathrm{l}$ was associated to a somewhat shorter duration of pregnancy. In multiple linear regression analysis, preterm labour was negatively related to gestational age. Considering both gestational age and birth weight together in 
logistic regression analysis, (with birth percentile as dependent variable), maternal smoking, presence of a small-for-date infant and pregnancy induced hypertension negatively predicted the birth percentile on the Amsterdam growth table.

Many of the first studies that drew attention to impaired pregnancy outcome associated with the presence of maternal cervical Chlamydia trachomatis infections have been performed in indigent populations in which the prevalence of this micro-organism was high. Several investigators have identified subsets of women within these populations particularly to be at risk. Young age, low educational attainment, single marital status, and public assistance, all have been associated with preterm birth and low birth weight. However, the demographic characteristics evaluated in these studies appear to be more descriptive than explanatory. Age, education and marital status themselves are unlikely to have a direct causal influence on the outcome of pregnancy. Rather, these factors are more likely to be an expression of a host of biological, behavioural, environmental and medical factors that are causally related to pregnancy outcome. Presumably, the results of these early reports therefore primarily reflected social class factors and not the urogenital infection per se.

Our results suggest that in pregnancy the presence of genital Chlamydia trachomatis, Mycoplasma hominis, Ureaplasma urealyticum, and asymptomatic bacteriuria in a healthy, economically stable population which is afforded modern antenatal care is not a major risk factor for prematurity or low birth weight. Several demographic, behavioural, and medical variables however were associated with decreased birth weight and prematurity. In all analyses, maternal smoking was found to be a prominent, (and in principle preventable), cause of decreased birth weight. In addition, the presence of a small-for-date child in the maternal reproductive history was highly indicative for the fetal birth weight of the pregnancy at issue. This finding should have implications as to the level of antenatal care for this group of pregnant women.

In conclusion, it appears from our results that in the population studied antenatal screening in order to prevent decreased birth weight and preterm birth should not be directed at Chlamydia trachomatis, Mycoplasma hominis, Ureaplasma urealyticum or asymptomatic bacteriuria. Rather, women should be urged to discontinue smoking during preg * nancy. Also, in view of the morbidity related to small-for-dates, antenatal care of pregnant women who already have a small-for-date child should be at an adequate level. 


\section{Literature}

1. Naessens A., Foullon W. et al. 1989. Postpartum bacteremia and placental colonization with genital mycoplasmas and pregnancy outcome.

Am.J.Obstet.Gynaecol. 160:647-651.

2. Harrison H.R, Alexander E.R. et al. 1983. Cerwical Chlamydia trachomatis and mycoplasmal infections in pregnancy: Epidemiology and outcomes.

J.Am.Med.Assoc. 250:1721-1727.

3. Berman S.M., Harrison H.R. et al. 1987. Low birth weight, prematurity , and postpartum endometritis. Association with prenatal cervical Mycoplasma hominis and Chlamydia trachomatis infections.

J.Am.Med.Assoc. 257:1189-1194.

4. Gravett M.G., Nelson H.P. et al. 1986. Independent associations of bacterial vaginosis and Chlamydiatrachomatis infection with adverse pregnancy outcome. J.Am.Medl.Assoc. 256:1899-1903.

5. Toomy K.E., Rafferty M.P. et al. 1987. Unrecognized high prevalence of Chlamydia trachomatis cervical infection in an isolated Alaskan Eskimo population.

J.Am.Med.A.Ssoc. 258:53-56.

6. Knottnerus J.A.y Delgado L.R. et al. 1988. Hemoglobine, hematocriet en zwangerschapsuitkomst.

Ned.Tijdschr.Geneeskd. 132:719-723. 


\section{Samenvatting en Discussie}

De daling van de neonatale mortaliteit tijdens de laatste decennia is vooral toe te schrijven aan de toegenomen overleving van à terme geboren kinderen. De belangrijkste oorzaken van neonatale mortaliteit en morbiditeit worden nu gevormd door vroeggeboorte en een geboortegewicht, te laag voor de duur van de zwangerschap (small-for-gestational-age; SGA).

Micro-organismen, tijdens de zwangerschap aanwezig in de tractus uro-genitalis van de moeder, worden sinds kort beschouwd als een van de mogelijke oorzaken van vroeggeboorte en een te laag geboortegewicht. Hiertoe behoren Chlamydia trachomatis, Mycoplasma hominis, Ureaplasma urealyticum en uropathogenen (Gram-negatieve bacteriën) welke een asymptomatische bacteriurie veroorzaken. De resultaten van studies naar een oorzakelijk verband van deze micro-organismen met een ongunstige zwangerschapsuitkomst zijn echter tegenstrijdig. Dit is enerzijds het gevolg van onbekendheid met het biologische mechanisme dat ten grondslag zou moeten liggen aan maternale cervicale infecties leidend tot vroeggeboorte respectievelijk een laag geboorte gewicht, anderzijds is dit het gevolg van feit dat de gevonden resultaten lijken te varieren met de onderzochte populatie.

Deze studie werd geïnitieerd tegen de achtergrond van de veronderstelde populatie-afhankelijke betekenis van Chlamydia trachomatis, $M y c o-$ plasma hominis, Ureaplasma urealyticum en asymptomatische bacieriurie en vanwege het ontbreken van gegevens betreffende het effect van deze micro-organismen bij Nederlandse zwangeren.

Een prospectieve epidemiologische studie van $z$ wangere vrouwen werd ontworpen ter beantwoording van de gestelde vragen. Gegeven de verwachtte prevalentie van de in het onderzoek betrokken genitale micro-organismen en van asymptomatische bacteriurie, was een grote onderzoekspopulatie, geraamd op 2000 vrouwen, noodzakelijk om statistisch betrouwbare antwoorden te verkrijgen. Dit kon slechts gerealiseerd worden in een samenwerking met meerdere klinieken.

Het succes van een op deze wijze ontworpen groot epidemiologisch onderzoek is afhankelijk van de discipline en coöperatie van alle deelnemers en daarenboven van de logistieke ondersteuning. Van geen van deze twee essentiele voorwaarden werd het optimale niveau gerealiseerd. Desalniettemin behoort de huidige studie, hoewel het beoogde 
aantal vrouwen niet werd bereikt, tot de grootste verloskundige epidemiologische studies in Nederland verricht. Met uitzondering van de gegevens betreffende Chlamydia trachomatis, lieten de verzamelde gegevens betrouwbare statistische analyse toe.

In de onderzochte studiegroep werd een prevalentie van $1.6 \%$ vastgesteld voor Chlamydia trachomatis, $5.0 \%$ voor Mycoplasma hominis, $27.4 \%$ voor Ureaplasma urealyticum en $9.2 \%$ voor een asymptomatische bacteriurie. De prevalentie van de drie genitale micro-organismen bevond zich aan de onderzijde van de range van percentages gevonden in andere studies [zie hoofdstuk 2, Tabel $2.2,2.5$ ]. In een vergelijkbare populatie in Belgie werd recent evenwel eenzelfde percentage voor Ureaplasma urealyticum gedetecteerd [1]. De onderlinge verhouding van de gevonden percentages kwam overeen met de verhoudingen elders. De prevalentie van asymptomatische bacteriurie bevond zich aan de bovenzijde van de verwachtte range.

De gerapporteerde verschillen in de aangehaalde studies kunnen voornamelijk worden toegeschreven aan verschillen in de karakteristieken van de onderzochte populaties en in de toegepaste detectie methode.

Door de jaren heen zijn de kweektechnieken voor asymptomatische bacteriurie en de genitale mycoplasmata practisch onveranderd gebleven. De detectie technieken voor Chlamydia trachomatis zijn echter niet onbelangrijk veranderd. Kweektechnieken, lang beschouwd als de gouden standaard, zijn geleidelijk vervangen door kweek-onafhankelijke methoden. De in deze studie toegepaste directe immunofluores" centie techniek (MicroTrak, Syva), is een goed gevalideerde, kweekonafhankelijke methode voor de detectie van Chlamydia trachomatis met een sensitiviteit van ongeveer $95 \%$, en een specificiteit wan 94 tot 99\%. In deze studie werd volgens het voorschrift van de fabrikant een "cut-off point" wan 10 fluorescerende partikels aangehouden waardoor de kans op een vals positieve testuitslag verwaarloosbaar klein wordt. Verlaging van het "cut-off point" naar 5 fluorescerende partikels, zoals door sommige auteurs gehanteerd, zou de resultaten van deze studie niet veranderen: slechts twee vrouwen meer zouden als positief moeten worden beschouwd. De directe immunofluorescentie test biedt het voordeel dat de kwaliteil van het afgenomen specimen beter te beoordelen is. Zo werden specimen zonder endocervicale cellen beschouwd als niet evalueerbaar. Met andere technieken zouden dergelijke specimen als negatief beoordeeld worden.

De samenstelling van de in deze studie onderzochte groep vrouwen verschilde in verschillende opzichten van de bestudeerde populaties in de Verenigde Staten van Amerika. In de belangrijkste Amerikaanse studies maakten zwangere tieners 23 tot $29 \%$ uit van de studiegroep 
$[2,3]$, terwijl in de huidige studie slechts $2.2 \%$ van de deelnemende vrouwen adolescenten waren. In dit licht bezien is het niet verwonderlijk dat een ongehuwde status van de moeder vaker werd wasargenomen in de buitenlandse studies. De gemiddeld hogere leeftijd van de deelnemende vrouwen vond zijn weerslag in het gemiddelde opleidingsniveau. In geen andere studie werd een vergelijkbaar hoog niveau van opleiding van de moeders gerapporteerd.

Het percentage nulliparae bij de onderzochte groep vrouwen kwam overeen met het percentage van sommige [3], doch niet van alle studies [4]. Vermeldenswaard is dat in de studie van Berman et al. [3] 25\% van de gescreende vrouwen jonger was dan 20 jaar. In deze laatste studie was $46 \%-52 \%$ van de bestudeerde vrouwen nullipara tegenover $34.8 \%$ in het huidige onderzoek.

In eerdere literatuur werd een omgekeerd evenredig verband gevonden tussen de leeftijd en de prevalentie van Chlamydia trachomatis. In thet algemeen werd de hoogste prevalentie gevonden bij jonge vrouwen in de leeftijd van 15 tot 21 jaar, met een sterke afname in hogere leeftijdsgroepen $[3,5]$. De relatief hogere leeftijd van de deelneemsters in de huidige studie zou mogelijk de gevonden-en verhoudingsgewijs lage - prevalentie verklaren. Interessant zou het daarom zijn de gevonden prevalentie te vergelijken met de prevalentie van Chlamydia trachomatis bij niet-zwangere vrouwen (tieners zowel als volwassenen) in deze regio. Helaas zijn deze cijfers niet beschikbaar. Op de polikliniek voor sexueel overdraagbare aandoeningen van het Academisch Ziekenhuis te Maastricht werd in de eerste zes maanden van 1989, bij 3 van de 38 daarop onderzochte personen (mannen zowel als vrouwen) Chlamydia trachomatis aangetoond (Prof. dr W.J.B.M. van der Staak, persoonlijke mededeling). Deze gegevens zijn uiteraard niet rechtstreeks vergelijkbaar met de cijfers uit deze studie daar deze personen een geselecteerde groep betreffen. Deze cijfers duiden er echter wel op dat de prevalentie van Chlamydia trachomatis in dit deel van Nederland relatief laag is.

Het tweede doel van deze studie was de aanwezigheid van uro-genitale micro-organismen tezamen met demografische, gedrags-en medische factoren bij zwangere vrouwen te relateren aan het geboortegewicht en de bereikte zwangerschapsduur. In de analyses werden het geboortegewicht en de zwangerschapsduur gedichotomiseerd volgens de mediaan. De berekende waarden voor de mediaan van de zwangerschapsduur (40.0 weken) en het geboorte gewicht $(3290 \mathrm{~g}) \mathrm{kwamen}$ overeen met algemeen aanvaarde waarden. Deze resultaten onderstrepen de validiteit van de verzamelde gegevens in deze studie.

Geen van de bestudeerde micro-organismen beínvloedde de zwangerschapsuitkomst rechtstreeks. Met behulp van trivariate analyse toonden 
wij aan dat aunwezigheid van asymptomatische bacteriurie bij vrouwen met Ureaplasma urealynicum geassocieerd was met een significant lager geboortegewicht. Echter, noch met behulp van multiple lineaire regressie analyse, noch met logistische regressie analyse kon deze relatie bevestigd worden. Met behulp van eenzijdige variantieanalyse bleken de leeftijd, de lengte, het opleidingsniveau, het rookgedrag en het hemoglobinegehalte van de moeder significant gerelateerd te zijn aan het geboortegewicht. Vergeleken met niet-rokers waren kinderen van rokende moeders gemiddeld $217 \mathrm{~g}$ lichter. Kinderen van jonge moeders ( $20-24$ jaar) waren lichter vergeleken met kinderen van moeders tussen 30-34 jaar. De meest plausibele verklaring voor dit verschil is de waarschijnlijkheid dat de pariteit groter wordt bij toenemende leeftijd van de moeder. Deze veronderstelling wordt bevestigd door Tabel 5.1 waarin het aantal vrouwen in categorieën gesorteerd naar oplopende moederlijke leeftijd in een kruistabel werd vergeleken met de pariteit.

Langere moeders en moeders met een hogere opleiding kregen zwaar" dere kinderen vergeleken met korte moeders en moeders met een laag opleidingsniveau. Een $\mathrm{Hb}$ van $\geq 8.0 \mathrm{mMol} / \mathrm{l}$ aan het begin van het derde zwangerschapstrimester was geassocieerd met een lager geboortegewicht vergeleken met normale concentraties. Deze bevinding komt overeen met de resultaten van Knottnerus et al. [6], die niet alleen een positieve relatie vond tussen een moederlijk $\mathrm{Hb}$ van $\geq 8.0 \mathrm{mMol} / \mathrm{l}$ aan het begin wan het derde zwangerschapstrimester en een laag geboortegewicht, maar ook met vroeggeboorte. De vrouwen in dat onderzoek waren afkomstig uit dezelfde regio als de vrouwen uit de onderhavige studie.

In de multiple lineaire regressie analyses bleken van de secundaire onafhankelijke variabelen roken, Hb en de aanwezigheid van een SGAkind in de obstetrische anamnese van de moeder geassocieerd te zijn met een verminderd geboortegewicht. Met behulp van enkelzijdige variantieanalyse bleek het moederlijke haemoglobine gehalte, gemeten aan het begin van het derde zwangerschapstrimester gerelateerd te zijn aan de $z$ wangerschapsduur. Een $\mathrm{Hb}$ van $\geq 8.0 \mathrm{mMol} / \mathrm{l}$ bleek geassocieerd te zijn met een licht verkorte zwangerschapsduur. In de multiple lineaire regressie anallyse bleek het optreden van premature contracties negatief gerelateerd te zijn aan de zwangerschapsduur. In logistische regressie analyse, (met het geboortepercentiel als afhankelijke variabele), bleken roken, de aanwezigheid van een SGA-kind en zwangerschapshypertensie het geboortepercentiel negatief te voorspellen.

Vele van de studies waarin de aandacht werd gevestigd op een mogelijke associatie tussen een ongewenste zwangerschapsuitkomst en de aanwezigheid van een maternale cervicale Chlamydia trachomatis infectie, zijn verricht in behoeftige populaties waarin de prevalentie van dit 
micro-organisme hoog was. Diverse onderzoekers identificeenden groepen vrouwen in dergelijke populaties met een duidelijk verhoogd risico. Adolescentie, een gering opleidingsniveau, een ongehuwde status en afhankelijkheid van sociale voorzieningen zouden alle geassocieerd zijn met vroeggeboorte en een te laag geboortegewicht. De demografische karakteristieken zoals geëvalueerd in deze studies lijken echter veeleer beschrijvend dan verklarend te zijn. Het is niet waarschijnlijk dat leeftijd, opleiding en huwelijkse staat een direct causale invloed hebben op de zwangerschapsuitkomst. Veel eerder lijken deze factoren een uiting te zijn van een constellatie van biologische, gedrags, omgevings en medische factoren die wel oorzakelijk gerelateerd zijn atan de zwangerschapsuitkomst. Waarschijnlijk zijn de uitkomsten van deze vroege studies dus eerder een afspiegeling van de invloed van factoren van de sociale klasse waartoe een zwangere vrouw behoort dan van de invloed van de infectie.

Onze resultaten suggereren dat tijdens de zwangerschap de aanwezigheid van genitale Chlamydia trachomatis, Mycoplasma hominis, Ureaplasma urealyticum en asymptomatische bacteriurie in een gezonde,economisch stabiele populatie, voorzien van modeme antenatale zorg, geen belangrijke risico factor zijn voor het ontstatan van prematuriteit of een laag geboortegewicht. Diverse demografische, gedrags en medische variabelen bleken geassocieerd te zijn met een verminderd geboortegewicht en prematuriteit. In alle analyses bleek roken tijdens de zwangerschap een belangrijke (en in principe vermijdbare) oorzaak te zijn voor een verminderd geboortegewicht. Daarnaast bleek de anwezigheid van een SGA-kind in de obstetrische anamnese sterk indicatief te zijn voor het geboortegewicht van het kind van de vigerende zwangerschap. Deze bevinding dient implicaties te hebben voor het niveau van antenatale zorg voor deze groep vrouwen.

Concluderend blijkt uit onze resultaten dat in de onderzochte populatie antenatale screening met het doel een verminderd geboortegewicht of vroeggeboorte te voorkomen niet gericht dient te zijn op Chlamydia trachomatis, Mycoplasma hominis, Ureaplasma urealyticum, of asymptomatische bacteriurie. Veeleer dient er bij vrouwen op aangedrongen te worden het roken tijdens de zwangerschap te staken. Tevens zou, met het oog op de aan een te laag geboortegewicht gerelateerde morbiditeit, de antenatale zorg voor moeders die eerder een SGA-kind kregen op een adequaat niveau dienen te zijn.

\section{Literatuur}

Zie hoofdstuk 5, pagina 88 voor de referenties van dit hoofdstuk. 


\section{Addendum 1}

\section{L_L L Volgnummer}

De invloed van subklinische urogenitale infecties op beloop en uitkonst van de graviditeit.

Vragenligst voor de patiënte bij de 1 zwangerschapscontrole.

U kunt antwoorden door het juiste anwoord aan te kruisen; als er puntjes staan dan gelieve $U U w$ antwoord duidelijk op te schrijven. Als $U$ een vragg niet begrijpt; of niet precies weet welk antwoord op u wan toepassing is, dan kunt $U$ zo dadelijk Uw gynaeco loog om uitleg vragen.

0. Datum L_L L_ dd/nm/jj Bedoeld wordt de datum warop U deze vragenlijst invult.

1. Verleent U Uw medewerking aan dit onderzoek?

$\mathrm{ja} \rightarrow \mathrm{Ga}$ naar vraag 2 .

neen $\rightarrow$ Waarom niet?

2. Welke is de hoogste schoolopleiding die U volgde/volg? Bijv. MULO MAVO, lagere school, BLO, huishoudschool, MMS, LEAO, MEAO, MO-akte, universiteit, etcetera).

3. Heeft $U$ deze opleiding met of zonder diploma afgesloten of bent $U$ er nog mee bezig?

- Met diploma

-Zonder diploma gestopt

- Nog mee bezig

4. Hoe lang is de vader van Uw baby?

.........

5. Hoeveel sigaretten rookt U per dag?

6. Hoeveel glazen alcoholhoudende drank gebruikt U per week?

7. Heeft U ooit een blaasontsteking gehad?

ja/neen $\rightarrow$ Ga naar vraag 10 .

8. Meer dan een natal?

ja/neen

9. Wanneer had $U$ de laatste blatanontsteking?

- Minder dan 3 maanden geleden

-3 Marden tot en met een jaar geleden

- Langer dan 1 jaar geleden

10. Heeft $U$ ooit mierstenen gehad?

$j a / n e e n \rightarrow$ Ga naar vraag 13 .

11. Meer dan 1 maal?

ja/neen 
12. Wanneer had $U$ de laatste nierstenen anval?

- Minder dara 3 maanden geleden

-3 Maanden tot en met een jaar geleden

- Langer dan 1 jaar geleden

13. Heeft U ooit een nierbekken ontsteking gehad?

ja/neen $\rightarrow$ Ga naar vraag 16

14. Meer dan 1 maal?

ja/neen

15. Wanneer had U de laatste nierbekken ontsteking?

- Minder dan 3 maanden geleden

-3 Maanden tot en met een jaar geleden

Langer dan 1 jaar geleden

16. Heef $U$ nog andere ziekten of afwijkingen van de nieren of urinewegen (gehad)? $\mathrm{ja} \rightarrow$ Welke?

neen

17. Bent U ooil alan de nieren of urinewegen geopereerd?

$\mathrm{ja} \rightarrow$ In welk ziekenhuis?

Welke operatie(s)?

neen

18. Heeft $U$ in de afgelopen 3 maanden een inwendig blaasonderzoek ondergaan?

ja, een blaascat theterisatie

ja, een cystoscopie

neen

19. Heeft $U$ de laatste weken vaak moeten plassen?

$\mathrm{ja}$, vaak $\rightarrow$ Heeft $U$ hiervoor een arts geraadpleegd?

ja/neen

neen

20. Heeft $\mathrm{U}$ de laatste weken last gehad van piin bij het plassen?

$\mathrm{ja}$, pign $\rightarrow$ Heeft $U$ hiervoor een arts geraadpleegd?

ja/neen

neen

21. Kon U de laatste weken Uw plas wel/niet goed ophouden?

Kon plas niet goed ophouden $\rightarrow \quad$ Heeft U hiervoor een arts geraadpleegd?

Kon plas wel goed ophouden

jatmeen

22. Heeft $\mathrm{U}$ ooit een ontsteking gehad van de vagina?

baarmoedermond?

-nooit $\quad-1$ keer

-2 of meer keren

eierstokken?

-nooit $\quad-1$ keer

-2 of meer keren

-nooit $\quad-1$ keer $\quad-2$ of meer keren

23. Wanneer begon Uw laatste menstruatie?

Datum $\mathrm{dd} / \mathrm{mm} / \mathrm{ij}$

Wilt $U$ kontroleren of $U$ alle vragen volledig en juist heeft beantwoord? Daanna kunt $U$ dit formulier aan de balie afgeven. 


\section{Addendum 2}

\section{Li, Vollgnummer}

De invloed van subklinische urogenitale infecties op beloop en uitkomst van de graviditeit.

Vragenlijst voor de patiente bij de $2^{\circ}$ monsterverzameling.

Geachte mevrouw,

Vijf maanden geleden besloot u mee te werken alan het onderzoek naar de mogelijke gevolgen van infecties van de blaas en de schede op de zwangerschap. Het is nu tijd voor de $2^{*}$ kontrole op de aanwezigheid van een infectie. Wilt $U$ a.u.b. een urinemonster in een flesje met een rode dop inleveren, onderstatande vragen invullen en dit formuliet dan aan de balie afgeven.

0. Datum L_L L d dd/mm/jj Bedoeld wordt de datum wasrop $U$ deze vragenlijst invult.

1. Hoeveel sigaretten rookt $\mathrm{U}$ per dag?

2. Hoeveel glazen alcoholhoudende drank gebruikt U per week?

3. Heeft $U$ in de afgelopen weken antibiotica gebruikt? ja/neen

4. Heeft $\mathrm{U}$ in de afgelopen weken een blatasontsteking gehad? ja/neen $\rightarrow$ Ga naar vraag 6 .

5. Heeft U hierwoor antibiotica gebruikt? ja/neen

6. Heeft U de laatste weken vaak moeten plassen?

ja, vaak $\rightarrow$ Heeft $U$ hiervoor een arts geraadpleegd? ja/neen

nieen

7. Heeft $U$ de latste weken last gehad van piin bij het plassen? ja, pijn $\rightarrow$ Heeft U hierwoor een arts getaadpleegd? ja/neen

neen

8. Kon U de laatste weken Uw plas wel/niet goed ophouden?

Kon plas niet goed ophouden $\rightarrow$

Heeft $U$ hiervoor een arts geraadpleegd?

Kon plas well goed ophouden $\mathrm{ja} /$ meen

Wilt $U$ kontroleren of $U$ alle vragen volledig en juist heeft beantwoord? Daarna kunt $U$ dit formulier aan de balie afgeven.

Dank voor Uw medewerking. 


\section{Addendum 3}

\section{Volgnummer}

De imvloed van subklinische wrogenitale infecties op beloop en witkomst van de graviditeit.

Gegevens m.b.t. de algemene- en werloskundige anamnese, het zwangerschapsverloop en de partus.

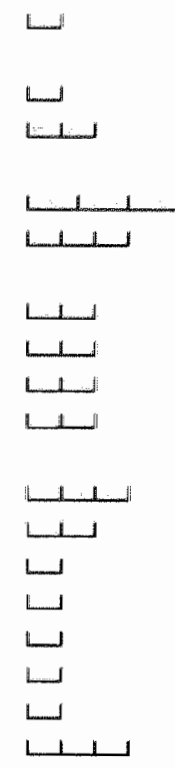

Medische indicatie?

$1=$ geen, $2=$ prim.med.ind, $3=$ sec.med.ind. $4=$ gyn $\rightarrow$ verlosk.

$1=$ observatie woortijdig gestaakt $2=$ monsterwerzameling geweigerd.

Zo ja, week van staken observatie/monsterwerzameling

Geboortedatum $\mathrm{dd} / \mathrm{mm} / \mathrm{jj}$

Lengre in $\mathrm{cm}$

$1^{*}$ Ziekte ooit gehad (codering vlgs LVR)

$2^{\text {c }}$ Ziekte ooit gehad (codering vlgs LVR)

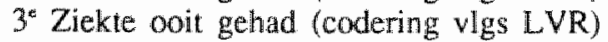

Serumcreatinine bij intake (niet in Heerlen)

Amenorrhoea bij intake in $w \mathrm{kn} / \mathrm{dgn}$

Pariteit

A terme dysmaturen $(7=7+)(p \leq 2.3)$

Immature partus $(7=7+)(16-28 \mathrm{wkn})$

Premature partus $(7=7+)(28-37 \mathrm{wkn})$

Zo jia, aantal hieronder dysmatuur

Abortus aantal inclusief AAP $(7=7+)(<16$ wkn $)$

Spontane abortus in huidige zwangerschap? Zo ja, amenorrhoea in wkn/dgn

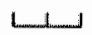

Hb bij am. 32 wkn

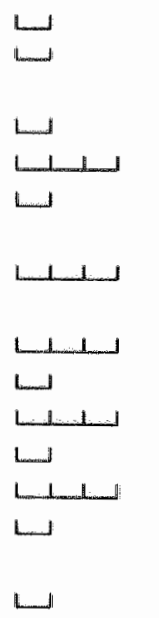

Hypertensie in zwangerschap $1=j a, 2=n e e n$

Diast. blueddruk 290 gedurende (minstens) 2 whin?

$1=$ ja $2=$ neen

Bloeddrukstigging $\geq 20$ in 2 wkn? $1=$ ja $2=$ neen

Toxicose vlgs arts. Zo ja, amenorrhoea in wkn/dgn

Zo ja, soort therapie $1=$ alleen Na beperking $2=$ opname geen medicatie $3=$ opname en medicatie $4=$ geen therapie $5=$ onbekend

Diabetes gravidarum? Zo ja, amenorrhoea in wkn/dgn

Im/prematuur gebroken wiezen?

Zo ja, geremd? $1=j$ ja $2=$ neen

Partus im/prematures imminens.

Zo ja, geremd? $1=$ ja $2=$ neen

Amenorrhoea bij partus in wkn/dgn

Betrouwbatarheid amenorrhoea bij partus $1=$ geen twijfel, $2=t<1$ w $3=1 \leq \mathrm{t}<2 \mathrm{wkn}, 4=2 \leq \mathrm{t}<3$ wkn, $5=3 \leq \mathrm{t}<4 \mathrm{wkn}, 6=\mathrm{t} \geq 4 \mathrm{wkn} 8=$ onbekend Electieve inductie partus $\|=j$ a $2=$ neen 


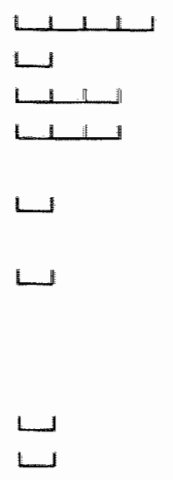

Geboortegewicht

Geslacht, neonatus $1=$ man 2 =vrouw

Arterièle navelstreng pH

Placentagewicht

Neonatale overleving bij partus $1=$ levendgeboren 2 =intra uterine vruchtood $3=$ sterfte durante partu

Opname neonatologie? $\mathrm{Zo} \mathrm{ja,} 1^{\circ}$ reden $0=$ geen opname $1=$ kunstverlossing $2=$ gewicht $<2500$ gram 3=gewicht $>4000$ gram $4=$ cong. niet chrom.

anomalie $5=$ chrom. anomalie $6=$ partus imprematures $8=$ observatie, reden (on)bekend

Zo ja, $2^{\circ}$ reden

Sterfte neonatus in $1^{\circ}$ week? $1=$ ja $2=$ neen $3=$ onbekend 


\section{Addendum 4}

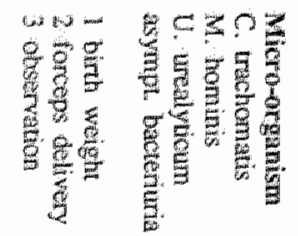

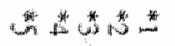

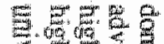
8

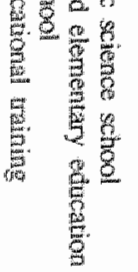

080

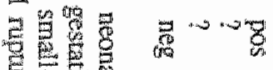

焉要

.

急总

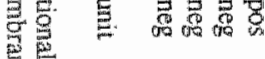

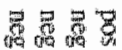

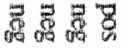

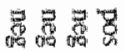

要要焉宽

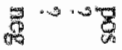

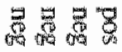

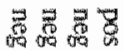

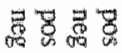

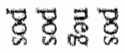

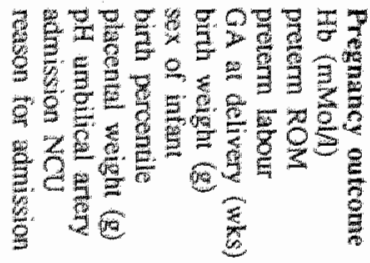

-

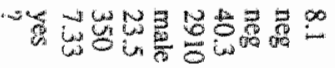

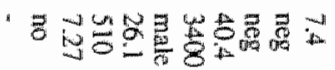
W 850

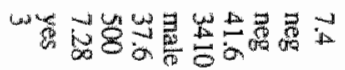

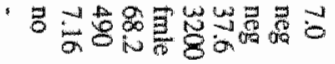

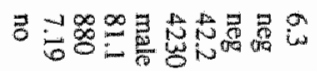

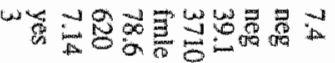

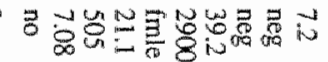
w落

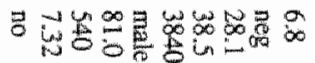

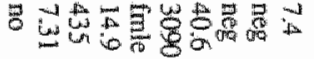

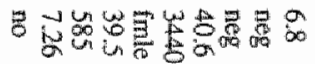

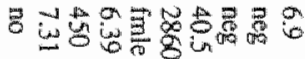

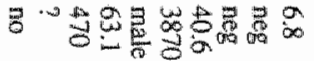

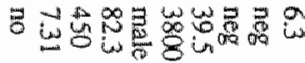

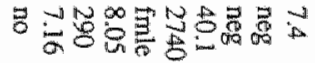

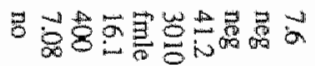

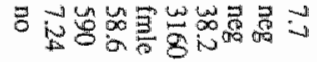

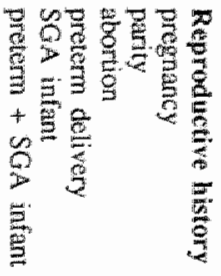

$00000-$

00000

OO-ninu

00000

$00000-$

00000

000000

$0000 m$

$00000-$

00000

0000nW

$0000^{\circ}$

0000 w w

$0000 \mathrm{~m}$

$0000-1$

$00000-$

$00000-$

$00000-$

$00000 \mathrm{~m}$

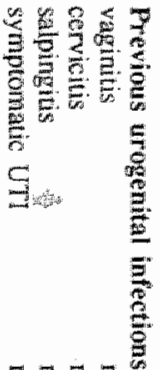

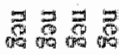

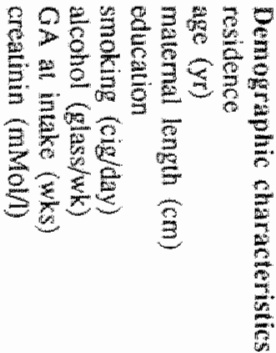

w心

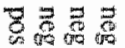

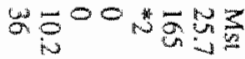

马

Mñ

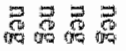

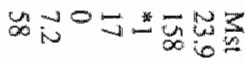

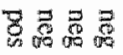

No $00 * \sigma 2$

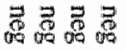

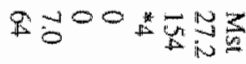

需

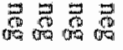

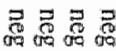

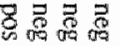

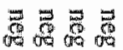

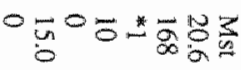

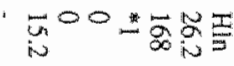

, tow $2 \frac{1}{6}$

ज.

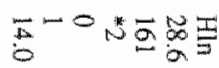

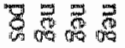

. $00 *-\frac{1}{3}$

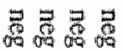

ow

焗以心

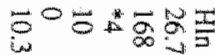

누ㅇㅛㅛ

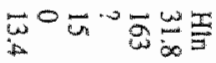

实要贾心

$0-5 * \sigma_{0}$

$8 \cdots$

心00

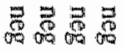

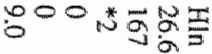

궁ำ

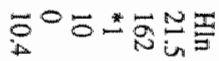




\section{Dankwoord}

Dit proefschrift kwam tor stand door samenwerking tussen de vakgroep Medische Microbiologie van de Rijksuniversiteit Limburg en de vakgroep Obstetrie en Gynaecologie van het Academisch Ziekenhuis Maastricht.

Het in de analyses verwerkte onderzoekmateriaal werd verzameld op de poliklinieken voor antenatale zorg van de Sint Elisabethklinick te Heerlen en het Academisch Ziekenhuis te Maastricht. Ook het de Wever ziekenhuis te Heerlen participeerde korte tijd in het onderzoek, doch om practische redenen zullen de aldaar verzamelde gegevens in een later stadium verwerkt worden.

Velen waren behulpzaam bij de uitvoering van het onderzoek en de voltooiing van het manuscript. Met name wil ik mijn dank betuigen aan:

De ruim vijftienhonderd zwangere vrouwen die, zonder enig persoonlijk belang, hun medewerking aan het onderzoek verleenden.

Dr P.X.J.M. Bouckaert en dr F.J.M.E. Roumen die, tezamen met hun staf en vele leerlingverloskundigen, het grootste deel van het onderzoekmateriaal aandroegen. Eens te meer demonstreerden zij hiermee de veelzijdigheid van de Sint Elisabethkliniek op wetenscliappelijk gebied. De leden van de gynaecologische staf uit Mastricht en met name de collega assistenten van destijds die een bijdrage aan het verzamelen van het materiaal leverden.

De polikliniek assistentes voor het met grote ijver en volharding vervullen van een cruciale functie in het onderzoek. Het klaarstaan met de vragenlijsten, het kweekmateriaal, de urinepotjes en de aanvraagbriefjes voor bloedmonsters vergde vooral tijdens drukke polidagen een krachttoer.

Agnes Gerritsen voor het consciëntieus invullen van de formulieren met zwangerschapsgegevens in de Sint Elisabethkliniek.

Drs A.E.J.M. van den Bogaard voor de geruisloze coördinatie van hel kweken van de genitale mycoplasmata.

Monique Wunderink en Paul Lemmens voor hun inzet in het laboratorium.

Mevrouw J.M.H. Philips die met opmerkelijk geduld bijna tweeduizend immunofluorescentie preparaten beoordeelde.

Ing R.J.G.C. Schmeitz, drs J.M. Nijhuis en mevrouw M.L.E.J. Kruijen van het Medisch en Maatschappelijk Informatiecentrum voor het inrichtten en voor het beheer van de gegevensbestanden. 
Ir P.H.J. Kurver die welwillend software beschikbaar stelde voor het berekenen van geboortepercentilen.

Dr B.I. Davies die het manuscript niel alleen taalkundig corrigeerde, maar het "en passant" ook wan inhoudelijk commentaar voorzag.

De promotores, prof. dr C.P.A. wan Boven en prof. dr J. de Haan, die elk op geheel eigen en soms verrassende wijze hun bijdrage aan dit proefschrift leverden.

De leden van de beoordelingscommissie voor de prompte beoordeling van het manuscript en hun waardevolle adviezen.

Dr F. Smits, wiens bijdrage zich uitstrekte tot buiten de grenzen van het onderzoek. Beste Frans, je steun en in het bijzonder je relativerende commentaren waren voor mij erg belangrijk.

Drs M.J.G. Luppes, die mij onvermoeibaar en blijmoedig leidde op het pad wan de exploratieve statistiek. Martin, het feit dat de verzamelde gegevens in een relatief korte periode verwerkt werden is jouw verdienste geweest.

Ing A.W. Houben, van wiens veelzijdige kennis en kunde ik veel heb geleerd. Beste Ton, ik weet nu onder meer dat bij automatische gegevenswerwerking enthousiasme alleen onvoldoende is.

Dr E.E. Stobberingh, voor de vasthoudendheid, het optimisme en het geduld waarmee zij niet alleen het onderzoek heeft begeleid. Beste Ellen, aan de tijd die wij samen aan dit proefschrift hebben gewerkt zal ik met plezier terugdenken.

Tenslotte dank ik mijn ouders door wie ik de opleiding van mijn keuze heb kunnen volgen. Aan jullie aandacht en zorg heeft het mij nooit ontbroken.

"Promoveren, it is mei sizzen net to dwaen". Lieve Han, zonder jouw opgewektheid en steun was dit proefschrift nooit geschreven. Tesamen met onze twee muiters vorm jij het thuisfront waar ik trots op ben.

Gewaardeerde steun en belangstelling kwam van:

Lederie Nederland B.V., Wyeth Laboratoria B.V., Schering Nederland B.V., Bayer Nederland B.V., Organon Nederland bv (Akzo's Pharma Divisie), Pie Data Medical en Pfizer B.V., producent van o.a. Vibra-S(B, Fasigyn®, Feldene® en Diflucan® 


\section{Curriculum vitae}

1955 Geboren te Paramaribo, Suriname op 4 juli

1975 Eindexamen VWO, Romboutscollege te Brunssum

1975-1982 Studie Geneeskunde, Katholieke Universiteit Nijmegen Studentassistent afdeling Embryologie en Anatomie Studentassistent afdeling Medische Psychologie

1981-1982 Werkzaam in het Government Hospital te Mafeteng, Lesotho

1982-1983 Wetenschappelijk medewerker afdeling Urologie, Katholieke Universiteit Nijmegen, Hoofd: prof. dr F.M.J. Debruyne "Experimentele prostaat tumoren"

1983 Waarnemend verzekeringsgeneeskundige GAK Waarnemend verzekeringsgeneeskundige Bedrijfs Geneeskundige Dienst, Nederlandse Spoorwegen

1984-1987 U-opleiding Obstetrie en Gynaecologie Academisch Ziekenhuis Maastricht Opleider: prof. dr J. de Haan

$1988 \quad$ A-opleiding Obstetrie en Gynaecologie de Weverziekenhuis, Heerlen Opleider: dr J.E.G.M. Stoot

1988 Detachering Streekziekenhuis Oranjeoord, Harlingen drs P.G.R.M. Hamers, gynaecoloog

1989 Inschrijving specialistenregister

1989 In maatschap met dr $\mathbb{B}$. van der Wild verbonden aan het dokter J.H. Jansen ziekenhuis te Emmeloord 